UNIVERSIDADE DE SÃO PAULO

ESCOLA DE ENFERMAGEM DE RIBEIRÃO PRETO

\title{
REPRESENTAÇÕES SOCIAIS DE MULHERES FRENTE À ADMISSÃO HOSPITALAR PARA A REALIZAÇÃO DA CIRURGIA POR CÂNCER DE MAMA
}

Cintia Bragheto Ferreira

Dissertação apresentada à Escola de Enfermagem de Ribeirão Preto da Universidade de São Paulo, para obtenção do Título de Mestre em Enfermagem em Saúde Pública junto ao Departamento de Enfermagem Materno-Infantil e Saúde Pública, inserida na Linha de Pesquisa Assistência à Saúde da Mulher no Ciclo Vital. 
UNIVERSIDADE DE SÃO PAULO

ESCOLA DE ENFERMAGEM DE RIBEIRÃO PRETO

\title{
REPRESENTAÇÕES SOCIAIS DE MULHERES FRENTE À ADMISSÃO HOSPITALAR PARA A REALIZAÇÃO DA CIRURGIA POR CÂNCER DE MAMA
}

Cintia Bragheto Ferreira

\begin{abstract}
Dissertação apresentada à Escola de Enfermagem de Ribeirão Preto da Universidade de São Paulo, para obtenção do Título de Mestre em Enfermagem em Saúde Pública junto ao Departamento de Enfermagem Materno-Infantil e Saúde Pública, inserida na Linha de Pesquisa Assistência à Saúde da Mulher no Ciclo Vital.
\end{abstract}

Orientadora: Prof. ${ }^{\text {a }}$ Dra. Ana Maria de Almeida 


\section{Ficha Catalográfica}

Preparada pela Biblioteca Central do Campus Administrativo de Ribeirão Preto /USP.

Ferreira, Cintia Bragheto

Representações sociais de mulheres frente à admissão hospitalar para a realização da cirurgia por câncer de mama, 2003.

160 p. $29,7 \mathrm{~cm}$.

Dissertação de Mestrado, apresentada à Escola de Enfermagem de Ribeirão Preto. USP, 2003.

Orientadora: Prof. ${ }^{a}$ Dra. Ana Maria de Almeida 
Data da defesa:

Banca Examinadora

Prof. ${ }^{a}$ Dra. Ana Maria de Almeida

Julgamento

Assinatura:

Prof. ${ }^{a}$ Dra. Ana Márcia Spanó Nakano

Julgamento

Assinatura:

Prof. a Dra. Rita de Cássia Gandini

Julgamento

Assinatura: 


\section{DEDICATÓRIA}

Aos meus pais, pelo trabalho incansável e contribuição decisiva para minha formação. Portanto, meus sinceros agradecimentos.

Ao Vicente, meu esposo, por ter acompanhado e incentivado o desenvolvimento deste trabalho.

Aos meus irmãos, pelo reconhecimento e importância dados a este estudo.

Ao meu avô Manoel, por ter me influenciado na escolha de minha profissão.

À Prof. ${ }^{a}$ Dra. Ana Maria de Almeida, pelas orientações pautadas na verdade, na justiça social e no estímulo à liberdade das escolhas. 


\section{AGRADECIMENTOS}

A Deus, por ter me auxiliado na percepção do que estava diante de meus olhos.

À Prof. a Dra. Rita de Cássia Gandini, por ter possibilitado meu primeiro contato com as mulheres com câncer de mama e pelas importantes contribuições para a estruturação deste trabalho.

À Prof. ${ }^{a}$ Tânia Mendonça Marques, por ter sido minha sustentação nos primeiros atendimentos que realizei às mulheres com câncer de mama.

À Ilda, por sua imensa generosidade.

À Prof. ${ }^{a}$ Dra. Maria das Graças B. de Carvalho, por ter acreditado em meu potencial.

À Prof. a Dra. Maria José Clapis, pela acolhida carinhosa e pelos primeiros ensinamentos em fazer pesquisa.

À Prof. ${ }^{a}$ Dra. Marli Vilela Mamede, pelas importantes contribuições nos momentos de delineamento de meus primeiros problemas de pesquisa.

Aos queridos amigos e profissionais que compõem o REMA, que sempre se mantiveram tão perto durante todo esse período.

Aos docentes da disciplina Seminário de Pesquisa em Saúde, pela contribuição imensa na definição do projeto deste estudo.

Ao Prof. Dr. Hélio Carrara, por ter me motivado na busca da realização de um trabalho mais crítico.

À Prof. ${ }^{a}$ Dra. Ana Márcia Spanó Nakano, por ter compartilhado seus conhecimentos sem medida. 
À Prof. ${ }^{a}$ Dra. Denise de Andrade e à Prof ${ }^{a}$ Dra. Antônia Regina Ferreira Furegato, pelos textos importantes para a construção deste trabalho.

A todos os profissionais de enfermagem que compõem a enfermaria na qual os dados deste estudo foram coletados, pela possibilidade de observá-los no exercício do procedimento da admissão hospitalar necessária para a realização da cirurgia por câncer de mama.

A todas as mulheres que participaram desta pesquisa, por terem compartilhado algo tão doloroso conosco.

A todos os funcionários da EERP-USP, por sempre terem se disponibilizado para que este trabalho pudesse ser realizado.

À Graziella, pela sua disponibilidade em me auxiliar nas dúvidas de informática.

À Berta, pela sua imensa contribuição na realização do resumo em espanhol.

À Biblioteca Central do Campus Administrativo de Ribeirão Preto /USP, pela revisão das referências bibliográficas. 
Registro que esta pesquisa foi financiada com recursos do Conselho Nacional de Desenvolvimento Científico e Tecnológico-CNPq. Reconheço que sem este financiamento seria muito difícil a realização deste estudo, que acredito ser importante para o desenvolvimento do conhecimento científico. 


\section{SUMÁRIO}

RESUMO

SUMMARY

RESUMEN

1. INTRODUÇÃO.............................................................................. 1

1. Revisão da literatura ......................................................................... 4

1.2 Fundamentos da Teoria das Representações Sociais-RS ...................... 16

1.2.1 A Psicologia Social e a Sociologia .................................................... 18

1.2.2 Histórico da Psicologia Social .......................................................... 19

1.2.3 O "repúdio positivista de Wundt" .................................................... 19

1.2.4 O "longo passado e o curto presente da psicologia” ............................. 20

1.2.5 “Formas e formas de contar histórias da psicologia social” ................. 20

1.2.6 Psicologia Social no Brasil ............................................................ 21

1.3 Teoria das Representações Sociais - RS .......................................... 22

1.4 Hospital: espaço de acolhimento e cura? ............................................. 27

$1.5 \quad$ Teoria do Enfrentamento ............................................................. 30

1.5.1 Enfrentamento versus comportamentos adaptativos automáticos ......... 31

1.5.2 Enfrentamento como processo ......................................................... 33

2. OBJETIVOS ....................................................................... 36

3. MÉTODO …....................................................................... 37

$3.1 \quad$ Tipo de estudo ............................................................................ 37

3.2 Contexto do estudo ..................................................................... 38

3.2.1 A enfermaria estudada ........................................................... 38

3.2.2 A admissão hospitalar na enfermaria de ginecologia e obstetrícia: contexto do estudo .................................................................. 39

3.3 Universo empírico ......................................................................... 40

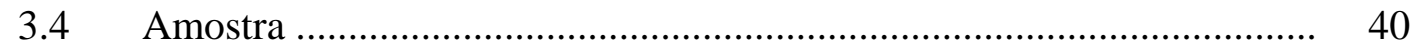

3.5 A entrada no campo ................................................................... 41

3.6 Instrumentos ........................................................................... 43 
3.7 A coleta de dados ...........................................................................

$3.8 \quad$ Período de coleta ............................................................................... 47

$3.9 \quad$ Aspectos éticos .......................................................................... 48

3.10 Análise dos dados ............................................................................ 48

4. RESULTADOS ……………………………………………..... 51

5. DISCUSSÃO DOS RESULTADOS ……………………………....... 88

5.1 REPRESENTAÇÕES SOCIAIS ...................................................... 106

5.2 ESTRATÉGIAS DE ENFRENTAMENTO …………........................ 120

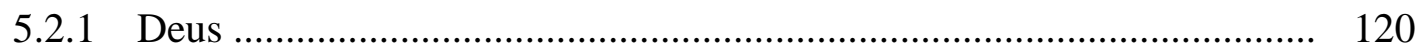

5.2.2 Médicos .................................................................................. 122

5.2.3 A busca interna ......................................................................... 126

5.2.4 Outras estratégias de enfrentamento utilizadas ..................................... 126

5.2.5 O contexto como facilitador das estratégias de enfrentamento ............... 127

5.2.6 A relação das representações sociais com as estratégias de enfrentamento utilizadas .................................................................... 132

6. CONCLUSÕES ....................................................................... 136

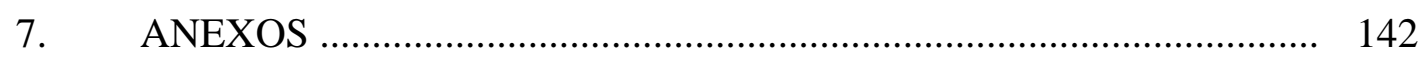

8. REFERÊNCIAS BIBLIOGRÁFICAS ................................................. 150 


\section{LISTA DE MAPAS ASSOCIATIVOS}

MAPA 1 Mapa das associações de idéias sobre admissão hospitalar necessária para a realização da cirurgia por câncer de mama presentes no discurso da entrevistada 1

MAPA 2 Mapa das associações de idéias sobre admissão hospitalar necessária para a realização da cirurgia por câncer de mama presentes no discurso da entrevistada 2

MAPA 3 Mapa das associações de idéias sobre admissão hospitalar necessária para a realização da cirurgia por câncer de mama presentes no discurso da entrevistada 3

MAPA 4 Mapa das associações de idéias sobre admissão hospitalar necessária para a realização da cirurgia por câncer de mama presentes no discurso da entrevistada 4

MAPA 5 Mapa das associações de idéias sobre admissão hospitalar necessária para a realização da cirurgia por câncer de mama presentes no discurso da entrevistada 5

MAPA 6 Mapa das associações de idéias sobre admissão hospitalar necessária para a realização da cirurgia por câncer de mama presentes no discurso da entrevistada 6 .....

MAPA 7 Mapa das associações de idéias sobre admissão hospitalar necessária para a realização da cirurgia por câncer de mama presentes no discurso da entrevistada 7

MAPA 8 Mapa das associações de idéias sobre admissão hospitalar necessária para a realização da cirurgia por câncer de mama presentes no discurso da entrevistada 8

MAPA 9 Mapa das associações de idéias sobre admissão hospitalar necessária para a realização da cirurgia por câncer de mama presentes no discurso da entrevistada 9

MAPA Mapa das associações de idéias sobre admissão hospitalar

10 necessária para a realização da cirurgia por câncer de mama presentes no discurso da entrevistada 10 


\section{LISTA DE GRÁFICOS}

GRÁFICO 1 Representações sociais de mulheres frente à admissão hospitalar para a realização da cirurgia por câncer de mama entrevistada 1

GRÁFICO 2 Representações sociais de mulheres frente à admissão hospitalar para a realização da cirurgia por câncer de mama entrevistada 2 ...

GRÁFICO 3 Representações sociais de mulheres frente à admissão hospitalar para a realização da cirurgia por câncer de mama entrevistada 3

GRÁFICO 4 Representações sociais de mulheres frente à admissão hospitalar para a realização da cirurgia por câncer de mama entrevistada 4

GRÁFICO 5 Representações sociais de mulheres frente à admissão hospitalar para a realização da cirurgia por câncer de mama entrevistada 5

GRÁFICO 6 Representações sociais de mulheres frente à admissão hospitalar para a realização da cirurgia por câncer de mama entrevistada 6

GRÁFICO 7 Representações sociais de mulheres frente à admissão hospitalar para a realização da cirurgia por câncer de mama entrevistada 7 .

GRÁFICO 8 Representações sociais de mulheres frente à admissão hospitalar para a realização da cirurgia por câncer de mama entrevistada 8

GRÁFICO 9 Representações sociais de mulheres frente à admissão hospitalar para a realização da cirurgia por câncer de mama entrevistada 9

GRÁFICO10 Representações sociais de mulheres frente à admissão hospitalar para a realização da cirurgia por câncer de mama entrevistada 10 


\section{RESUMO}

FERREIRA, C.B. Representações sociais de mulheres frente à admissão hospitalar para a realização da cirurgia por câncer de mama. 2003. 160p. Dissertação Mestrado- Escola de Enfermagem de Ribeirão Preto da Universidade de São Paulo.

Por existirem poucos estudos sobre o momento da internação hospitalar para a realização da cirurgia por câncer de mama, decidiu-se melhor compreender este momento a partir do referencial da teoria das representações sociais e da teoria do enfrentamento, buscando-se em um grupo de mulheres a identificação do significado da admissão hospitalar necessária para a realização da cirurgia, bem como as estratégias de enfrentamento por elas utilizadas nesse momento. A coleta de dados foi realizada numa amostra composta por 10 mulheres e pelos principais profissionais envolvidos em suas admissões. Com as mulheres foram realizadas observações participantes com a utilização do diário de campo e entrevistas semi-estruturadas, analisadas qualitativamente; e os profissionais foram observados com a utilização de um instrumento aberto-fechado, analisado qualitativa e quantitativamente. Em relação às mulheres, foram identificadas as seguintes categorias: perda da mama, medo da morte, cura, cuidado enquanto estratégia de retorno à saúde e dia normal. As estratégias de enfrentamento identificadas foram: médicos, Deus, ela própria, crenças próprias, família, namorado, outros que passaram pela mesma experiência, coragem, confiança, força de vontade, oração, não pensar e convivência com pessoas brincalhonas capazes de passar energia boa. A análise conjunta das representações sociais com as estratégias de enfrentamento evidenciou que em $70 \%$ das participantes houve relação entre o significado atribuído à admissão hospitalar e as estratégias de enfrentamento utilizadas. A relação entre as representações sociais e as estratégias de enfrentamento mostrou que as categorias: cura, cuidado enquanto estratégia de retorno à saúde e dia normal foram as mais eficazes no enfrentamento da admissão hospitalar. $\mathrm{O}$ instrumento utilizado com os principais profissionais que realizaram as admissões hospitalares mostrou que 100\% dos principais responsáveis pelas admissões hospitalares foram enfermeiras; $100 \%$ delas tentaram estabelecer um vínculo positivo com as mulheres no momento do chamamento; $80 \%$ não se apresentaram às mulheres que receberam; $90 \%$ utilizaram preferencialmente o termo senhora no período em que permaneceram com as mulheres; $100 \%$ demonstraram preocupação com o ambiente físico relacionado à admissão hospitalar; $70 \%$ mostraram-se dispostas a ouvir as mulheres recebidas; $80 \%$ receberam as mulheres na posição ereta e, $60 \%$ das admissões hospitalares ocorreram com a presença de uma enfermeira e uma auxiliar de enfermagem. Alguns desses dados permitiram verificar que esses profissionais forneceram suporte às mulheres, mas ao mesmo tempo outros dados mostraram que estes mesmos profissionais se distanciaram de um cuidado capaz de contemplar os aspectos físicos, mentais e espirituais dessas mulheres. Pontua-se, a partir desta análise, a necessidade do estabelecimento da subjetividade no momento da internação como forma de identificação das necessidades das mulheres com câncer de mama. Para tanto, sugere-se a construção de um complemento para o protocolo de admissão hospitalar atualmente utilizado na enfermaria, onde os dados deste estudo foram coletados.

Palavras-chave: Câncer de Mama; Admissão Hospitalar; Representações Sociais. 


\section{SUMMARY}

FERREIRA, C.B. Social Representations of women front to the hospital admission for the accomplishment of the surgery for breast cancer. 2003. 160p. Master Dissertation - University of São Paulo at Ribeirão Preto College of Nursing.

For existing few studies on the moment of the hospital internment for the accomplishment of the surgery for breast cancer, it was more good decided to understand this moment from the referencial of the theory of the social representations and the theory of coping, searching in a group of women the identification of the meaning of the necessary hospital admission for the accomplishment of the surgery. The collect of data was carried through in a composed sample for 10 women and the main involved professionals in its admissions. With the women were done participant observations with utilization of field notes and semi-structured interviews that were qualitative analyzed, and the professionals were observed with utilization of open-closed instrument, that was analyzed in a qualitative and quantitative way. In relation to the women, were identified these categories: loss of the breast, fear of the death, cure, care while return strategy the health and normal day. The strategies of coping identified were: physicians, God, herself, own believes, family, boyfriend, others that had passed for the same experience, courage, confidence, will-power, prayer, don't think and stay together of joking people that are capable to pass good energy. The analyze of social representations and strategies of coping together showed that in $70 \%$ of participants were relation between the meaning attributed to he hospital admission and the strategies of coping used. The relation between social representations and strategies of coping showed that the categories: cure, holistic care and normal day were the most effective in the coping of hospital admission. The instrument used with the main professionals who had carried through the hospital admissions showed that $100 \%$ of these professionals were nurse; $90 \%$ had used the term preferential lady in the period where they had remained with the women; $100 \%$ had demonstrated concern with the related physical environment to the hospital admission; $70 \%$ had revealed made use to hear the received women; $80 \%$ had received the women in erect position e, $60 \%$ of the hospital admissions had occurred with the presence of a nurse and one nurse aid. Some of these data had allowed to verify that these professionals had supplied support to the women, but at the same time other data had shown that these same professionals were distant of a care capable to contemplate the physical aspects, mental and spirituals of these women. From this analyze the necessity of the establishment of subjectivity in the moment of admission is emphasized as form of identification of the necessities of the women with breast cancer. For this, it is suggested construction of a complement for the protocol of hospital admission currently used in the infirmary, where the data of this study had been collected.

Key words: Breast Cancer; Hospital Admission; Social Representations. 


\section{RESUMEN}

FERREIRA, C.B. Representaciones sociales de mujeres frente a la admisión hospitalaria para la realización de la cirugía por cáncer de mama. 2003. 160p. Disertación Maestrado- Escuela de Enfermería de Ribeirão Preto de la Universidad de São Paulo.

Actualmente existen pocos estudios sobre el momento de la hospitalización para una cirugía de mama, y por ello se tomó la decisión de comprender mejor ese momento, a partir del referencial de la teoría de las representaciones sociales y de la teoría del enfrentamiento. Se buscó en un grupo de mujeres, identificar el significado de la admisión hospitalaria necesaria para realizar la cirugía, así como todas las estrategias que ellas utilizan para enfrentar ese momento. La recopilación de datos se hizo a través de una muestra formada por 10 mujeres y por los principales profesionales involucrados en sus admisiones. Con las mujeres, se realizaron observaciones participativas, utilizándose un diario de campo y entrevistas semiestructuradas, analizadas cualitativamente; y con respecto a los profesionales, éstos fueron observados utilizándose un instrumento abierto-cerrado, el cual fue analizado cualitativa y cuantitativamente. Con relación a las mujeres, fueron identificadas las siguientes categorias: pérdida de la mama, miedo de la muerte, mejoría, cuidados en relación a la estrategia de recobrar la salud y día normal. Fueron identificadas las siguientes estrategias utilizadas para enfrentar ese momento: médicos, Dios, ella misma, creencias propias, familia, pareja, otras mujeres que pasaron por la misma experiencia, coraje, confianza, fuerza de voluntad, rezos, no pensar y convivir con personas juguetonas capaces de pasar una buena energía. El análisis conjunto de las representaciones sociales con las estrategias de enfrentamiento dejó en evidencia que en un $70 \%$ de las participantes hubo relación entre el significado atribuido a la admisión hospitalaria y las estrategias de enfrentamento utilizadas. La relación entre las representaciones sociales y las estrategias de enfrentamiento mostró que las categorias: cura, cuidados en relación a la estrategia de recobrar la salud y dia normal fueron las más eficaces para enfrentar la admisión hospitalaria. El instrumento utilizado con los principales profesionales que realizaron las admisiones hospitalarias mostró que el $100 \%$ de los principales responsables por las admisiones hospitalarias fueron enfermeras; el 100\% de ellas intentaron establecer un vínculo positivo con las mujeres al momento del llamado; un 80\% no se presentó a las mujeres que recibían; un 90\% utilizó preferencialmente el tratamiento de Usted durante el período en que permanecieron con las mujeres; el 100\% demostró preocupación con el ambiente físico relacionado a la admisión hospitalaria; un 70\% se mostró dispuesta a oir a las mujeres que recebía; un 80\% recibió a las mujeres en posición erecta y, un $60 \%$ de las admisiones hospitalarias ocurrieron ante la presencia de una enfermera y de una auxiliar de enfermería. Algunos de estos datos permitieron verificar que esos profesionales entregaron ayuda a las mujeres, pero al mismo tiempo otros datos mostraron que estos mismos profesionales se alejaron de una atención capaz de contemplar los aspectos físicos, mentales y espirituales de esas mujeres. Se concluye, a partir de este análisis, la necesidad de establecer la subjetividad en el momento de la hospitalización como una forma de identificarse con las necesidades de las mujeres con cáncer de mama. Por tanto, se sugiere la construción de un complemento para el protocolo de admisión hospitalaria actualmente utilizado en enfermería, en el lugar donde los datos de este estudio fueron recolectados.

Palabras-clave: Cáncer de Mama; Admisión Hospitalaria; Representaciones Sociales. 


\section{INTRODUÇÃO}

O processo do adoecer por câncer e suas conseqüências sempre foram questões que me instigaram. Desde o primeiro estágio no curso de psicologia, no qual tive os primeiros contatos com mulheres com câncer de mama, percebi a importância de uma melhor compreensão dos vários momentos que uma mulher necessita enfrentar diante do impacto causado pelo diagnóstico, bem como possibilitar o repensar das práticas de assistências adotadas atualmente.

Esta primeira experiência iniciou-se em agosto de 1997, quando ingressei no estágio em Psicologia clínica, no Serviço de Mastologia Maligna do Setor de Ginecologia do Hospital de Clínicas da Universidade Federal de Uberlândia-UFU. O estágio teve duração de um ano e meio, e nesse período desenvolvemos o trabalho de atendimento psicológico através de um grupo de cinco estagiárias e duas supervisoras. O atendimento psicológico compreende a abordagem individual da paciente na clínica da própria Universidade e no Ambulatório de Ginecologia, atendimento domiciliar e atendimento na enfermaria de ginecologia do hospital. Além do atendimento individual, o serviço de psicologia organiza grupos informativos para mulheres com suspeita ou diagnóstico de câncer de mama. O grupo se reúne às sextas-feiras quando as pacientes são consultadas no Serviço de Mastologia Maligna do Ambulatório. O grupo tem como objetivo o esclarecimento de dúvidas que as próprias mulheres trazem frente ao diagnóstico e tratamento do câncer de mama, bem como as conseqüências psicossociais decorrentes do problema das pacientes. Esse esclarecimento é realizado pelas estagiárias que estimulam a 
participação das próprias pacientes que já passaram por situações, tais como a quimioterapia. Após relatarem como se dá o processo, outras pacientes que passarão pelo mesmo tipo de tratamento, poderão ter esclarecidas suas dúvidas e, possivelmente, terão condições de trabalhar sua ansiedade, seus medos e mitos.

Desenvolvendo um trabalho como voluntária no Núcleo de Ensino, Pesquisa e Assistência na Reabilitação de Mastectomizadas - REMA, do Departamento de Enfermagem Materno-Infantil e Saúde Pública da Escola de Enfermagem de Ribeirão Preto da Universidade de São Paulo - EERP-USP, percebo que uma mulher com câncer de mama é colocada a vivenciar vários momentos, que englobam desde a maneira como algum sintoma do câncer foi sentido até a fase em que essa mulher passa a conviver com a incerteza da volta da doença.

O câncer de mama é temido pelas mulheres por causa de sua alta freqüência e, principalmente pelos seus efeitos psicológicos. "As estatísticas apontam que ele é relativamente raro antes dos 35 anos de idade, mas acima desta faixa etária sua incidência cresce rápida e progressivamente” (Brasil, 1999, d).

Dados do Ministério da Saúde (Brasil, 2001, a) apontam o Brasil com um quadro sanitário em que se combinam doenças ligadas à pobreza, típicas dos países em desenvolvimento e doenças crônico-degenerativas, características dos países mais desenvolvidos. Essa situação reflete, inquestionavelmente, as contradições do processo de desenvolvimento do país.

As estatísticas indicam o aumento na freqüência do câncer de mama tanto nos países desenvolvidos quanto nos países em desenvolvimento. Segundo a Organização Mundial de Saúde (OMS), nos anos 1960 e 1970, registrou-se um aumento de 10 vezes em suas taxas de incidência, ajustadas por idade nos registros de câncer de base populacional de diversos continentes. Tem-se documentado também o aumento no risco de mulheres migrantes de áreas de baixo risco para áreas de risco alto. Nos Estados Unidos, a Sociedade Americana de Cancerologia indica que uma em cada 10 mulheres tem a probabilidade de desenvolver um câncer de mama durante a sua vida (Brasil, 2001, c).

Além disso, a redução das taxas de natalidade e mortalidade em idades prematuras contribui para a mudança na estrutura etária da população brasileira, tornando-a mais velha, do ponto de vista demográfico. Neste sentido, o Ministério da 
Saúde (Brasil, 1999, b) alerta para o aumento do número de pessoas que passam a compor as faixas etárias que apresentam risco de desenvolver câncer.

Para o ano 2003, a estimativa é de que o câncer de pele, por exemplo, será o principal a acometer a população brasileira, com 39.000 casos novos entre homens e 43.155 entre mulheres, seguido pelo câncer de mama, cujas estimativas indicam que para o ano de 2003 poderão ocorrer 9.335 óbitos por câncer de mama e 41.610 novos casos, que correspondem em taxas brutas a 10,4 óbitos em cada 100.000 (cem mil) habitantes e 46,35 novos casos para cada 100.000 habitantes (Brasil, 2003, e).

Os dados apresentados apontam o câncer de mama como um grande problema de saúde pública, que por isso necessita ser pesquisado para que novos programas possam ser elaborados com o objetivo de melhorar a qualidade de vida das pessoas com esse diagnóstico.

O câncer de mama é uma doença que historicamente foi associada ao término da menstruação (Yalom, 1998) e a sentimentos negativos como a vergonha.

\footnotetext{
“...vergonha de ter sido afetado por uma doença, tradicionalmente, considerada inglória, relegada aos bastidores da cultura. Vergonha de abrigar um mal marcado pela imagem da corrosão, do desregramento orgânico ou do castigo divino. Vergonha que tende a transformar o doente no único responsável por seus sofrimentos. Por conseguinte, os modos de enfrentamento* do câncer permanecem, em grande medida, confinados ao silêncio, principalmente quando se trata do câncer de mama, pois neste caso, a vergonha é agravada pela ameaça da mutilação de uma parte do corpo considerada, há muito, um dos principais símbolos da identidade feminina” (Sant'Anna, 1997, p.43-4).
}

Além disso, apesar das transformações técnico-científicas há ainda a persistência de temores e expectativas em relação ao câncer. Afirma Sant'Anna (1997): "Receios antigos relativos à mutilação, à solidão e ao abandono familiar não cessam de emergir no decorrer do tratamento em quimioterapia, por exemplo" (p.43-4).

\footnotetext{
* "O enfrentamento refere-se ao que o indivíduo pensa e faz para lidar com situações estressantes” (Gimenez et al, 1992, p. 353).
} 
As dificuldades para uma pessoa enfrentar um câncer sempre foram incontáveis. Isso porque ele sempre esteve ligado a inúmeros constrangimentos, como à associação entre câncer e falta de limpeza do corpo e da alma, pregada nas primeiras décadas do século passado. Assim, o câncer foi comparado à sífilis no que dizia respeito ao seu contágio, adquirida por meio de práticas viciosas e da "sujeira”, tanto moralmente quanto fisicamente. Além disso, havia a analogia do câncer como um bicho que ia devorando a pessoa por dentro. O câncer foi sinônimo também de sacrifício e purificação. Sacrifício porque o doente teria que suportar o sofrimento até a morte, e purificação, porque se achava que tocando os corpos de mulheres com câncer se obtinha um estoque de pureza (Sant'Anna, 1997).

A partir de 1930 surgiram novas indagações em relação às possíveis causas do câncer. Por exemplo:

“...a ingestão cotidiana de produtos químicos presentes nos alimentos, o hábito de fumar e até mesmo o uso de aparelhos domésticos como a geladeira. O excesso de trabalho e o aumento de preocupações se transformaram em fatores predisponentes ao câncer. As células malignas são células do próprio doente, apenas com algumas alterações” (Sant'Anna, 1997, p. 57).

Vários foram os tratamentos alternativos utilizados pelos povos ao longo da história. Sabe-se do tratamento, na Europa durante o século das Luzes, com sanguessugas e outras formas de sangrias, porque se acreditava que dessa maneira o sangue fluiria evitando as dores do câncer e o próprio câncer também. Segundo Sant’Anna (1997), no Brasil em 1946 houve a utilização de “tratamentos com xaropes, pílulas, depurativos, benzeduras e passes” (p. 47).

\subsection{Revisão da literatura}

Em 1991, em um trabalho de Mamede et al, intitulado: “Câncer: um conceito social”, percebe-se que há realmente uma necessidade de mais estudos que 
identifiquem outras dimensões do conceito câncer elaborado na mente da população, visto que vários estudos têm retratado esboços do pensamento das pessoas sobre o câncer como: doença que mais mata, a mais séria do mundo, a mais angustiante, a mais dolorosa, doença enraizante, dentre outros conceitos. Estes dados vêm reforçar a convicção de que a problemática gerada pelo câncer não é simplesmente de ordem cognitiva mas que tem repercussão social, psicológica, emocional e cultural. E a psicologia, por meio de suas pesquisas, parece estar conseguindo contemplar essa complexidade, o que se evidencia na literatura estudada.

As intervenções psicológicas que embasam o trabalho junto às pacientes com câncer de mama são classificadas na literatura, segundo Gandini (1995), como: psicossocial e psicoterápica. $\mathrm{O}$ primeiro tipo de intervenção pode ser operacionalizado em três tipos básicos: educacional cujo objetivo é dar informações ao paciente sobre o sistema de saúde; aconselhamento, que busca possibilitar e encorajar os pacientes a externarem seus sentimentos, e a manipulação ambiental, que consiste em falar sobre os pacientes, com pessoas que cuidam da saúde deles. A intervenção psicoterápica apresenta-se sobre a forma de diversas orientações e uma delas é a psicoterapia breve suportiva, cujo objetivo é levar tão rapidamente quanto possível, o paciente ao equilíbrio emocional, com a supressão ou atenuação de sintomas, de tal modo que ele possa, no presente, retomar o funcionamento em um nível próximo à fase anterior à crise, especificamente a crise desencadeada pelo diagnóstico do câncer. Não está entre os objetivos a mudança de estrutura da personalidade.

Um estudo longitudinal realizado por Queiroz (1993), objetivou investigar a existência e a natureza de possíveis relações entre fatores psicossociais e o bem-estar psicológico em mulheres com câncer de mama, mais especificamente, o papel do enfrentamento no bem-estar psicológico dessas mulheres. Para que esses objetivos fossem alcançados, foram entrevistadas mulheres portadoras de câncer de mama em três momentos distintos: 48 horas $(\mathrm{N}=36)$, três meses $(\mathrm{N}=28)$ e um ano pós mastectomia $(\mathrm{N}=13)$.

Os dados apresentados foram submetidos a uma análise de regressão múltipla, que não demonstrou uma diferença significativa nos índices de bem-estar psicológico medido nos três momentos de coleta dos dados. As entrevistas colhidas foram do tipo 
estruturada com 87 itens, que caracterizaram a amostra. Ficou evidenciado o apoio social percebido pela mulher (questões 13 a 19) e a facilidade em acessar os serviços de saúde (questões 24 a 27).

Foram também aplicadas as seguintes escalas: Escala de Comportamento Familiar; Escala de Saúde Mental; Escala de Avaliação de Expectativas e a Escala de Modos de Enfrentamento. A primeira escala, composta por 29 itens, foi utilizada para avaliar as estratégias familiares de enfrentamento, enquanto que a segunda escala, formada por 43 itens, forneceu uma medida de saúde mental global. A terceira escala, com 24 itens, mediu a percepção de controle que o sujeito tinha da situação (controle), o quanto a situação estressante do momento estava em evidência (saliência), a ocorrência ou não de uma situação parecida anteriormente (novidade), a percepção de tempo do evento (duração), a causalidade e a percepção do que aconteceria logo após com o evento em questão; e a Escala de Modos de Enfrentamento, com 56 itens, mediu as estratégias de enfrentamento enquanto processo, o que significou interpretá-las não apenas como uma reação específica a um evento estressante, mas também, como uma tentativa de manejar melhor a situação a que estavam expostas.

Além das entrevistas estruturadas e aplicação das escalas, utilizou-se uma ficha clínica, com 45 itens, elaborada por mastologistas, cujo objetivo era obter informações sobre o estado clínico das participantes da pesquisa. A partir desses dados, foram analisadas as seguintes variáveis independentes: características demográficas, condição clínica, recursos ambientais, estilo individual de enfrentar problemas e, bem-estar psicológico.

Os resultados proporcionaram a caracterização da amostra. A idade variou de 28 a 65 anos, com uma média de aproximadamente 48 anos. O nível de instrução variou do primeiro grau incompleto $(36,1 \%)$ ao curso superior $(19,4 \%)$. A renda familiar variou de 0 a 29 salários mínimos da época. A maioria das mulheres era casada e vivia com o marido, enquanto que o menor percentual 5,6\% era composto por mulheres casadas que não viviam com o marido. A religião predominante da amostra era a católica (77,8\%), e apenas $2,8 \%$ não tinham religião. As razões para a realização da cirurgia foram: existência de um “tumor maligno” (36,1\%); 27,8\% por 
ter "câncer”; 35\% pelo fato da presença de um "caroço"; 5,6\% por possuir "aquela doença”; 2,8\% por ter um “carcinoma” e, 2,8\% porque o médico decidiu.

Verificou-se ainda que 48 horas após a cirurgia, 38,9\% das mulheres já haviam passado por um tratamento adjuntivo, contra $61,1 \%$ que não foram submetidas ao tratamento adjuntivo. Três meses após a cirurgia, 89,28\% da amostra haviam passado por tratamento adjuntivo e 10,72\% não. Sobre a história de doença mamária 69,4\% não tinham história de doença mamária prévia; 11,1\% já tinham tido alguma doença mamária benigna prévia e, 19,5\% ignoravam a ocorrência ou não de câncer.

A análise de regressão múltipla evidenciou a relação entre variáveis independentes e a variável-critério, bem-estar psicológico. Verificou-se também que 48 horas após a cirurgia, a variável independente que mais influenciou o bem-estar emocional foi o modo de enfrentamento "culpar os outros”, seguida pela variável duração, que verificou a duração do evento estressante, depois pela causalidade e por pensamento esperançoso. Entretanto, a única variável que influenciou diretamente o bem-estar psicológico foi o acesso aos serviços de saúde. Três meses após a cirurgia, o bem- estar psicológico foi influenciado pela variável acesso aos serviços de saúde aliada ao pensamento esperançoso. Um ano após a cirurgia, o bem-estar psicológico pôde ser explicado pelas variáveis: culpar os outros, duração, causalidade, acesso aos serviços de saúde e pensamento esperançoso.

Ficou evidente que os modos de enfrentamento culpar os outros e pensamento esperançoso foram os que mais influenciaram, ainda que negativamente, o bem-estar psicológico das participantes, 48 horas após a cirurgia. O pensamento esperançoso foi o modo de enfrentamento que mais afetou o bem-estar psicológico das mulheres três meses após a mastectomia. E, um ano após a cirurgia, a variável focalizar no positivo foi a única que apareceu correlacionando-se positivamente ao bem-estar psicológico.

A ausência de diferença estatisticamente significativa entre o índice de bemestar psicológico nos três momentos da coleta de dados parece estar relacionada ao tratamento do câncer, que implica em necessidades individuais, representando assim, eventos estressantes singulares. O que vai ao encontro de que o enfrentamento não é algo único que alguém realiza, e sim, um conjunto de respostas de troca entre sujeito 
e ambiente. Respostas que não necessariamente são mais eficazes que outras para manejar eventos estressantes, cada uma apresenta vantagens e desvantagens, que serão selecionadas por cada sujeito dependendo de seus recursos internos e externos.

Num estudo realizado por Schulze (1993) denominado: “As representações sociais de pacientes portadores de câncer”, discutiu a contribuição da teoria das representações sociais no diagnóstico psicossocial, inserindo a discussão no contexto da psicologia da saúde. Foram entrevistados sessenta pacientes portadores de câncer submetidos a tratamento radioterápico ou quimioterápico. As entrevistas foram do tipo semi-estruturado com duração média de 30 a 40 minutos. As questões se referiam às causas da visita ao hospital, a como a doença foi detectada e as primeiras medidas tomadas, a forma como o paciente definia saúde e doença, como ele definia a doença no corpo e o modo como eram efetuados os cuidados corporais, além de como a perda e a morte eram encaradas. As entrevistas foram gravadas, transcritas e organizadas em um banco de dados, com a utilização de uma análise do tipo categorial-temática. O maior número de respostas permaneceu entre as estratégias tentar não se preocupar e preocupar-se com as mudanças no corpo, decorrentes do processo da doença e dos efeitos do tratamento. Entretanto, a autora julga que as estratégias de enfrentamento adequadas deveriam corresponder a formas de luta contra o desenvolvimento da doença.

Osowiecki \& Compas (1999) realizaram um estudo sobre a percepção de controle e adaptação psicológica ao câncer de mama. Para tanto, participaram setenta mulheres com média de idade de 54.86 anos e média de permanência na escola de 14.17 anos. Além disso, 67\% eram casadas ou viviam com um parceiro e 89\% tinham filhos, sendo que no critério diagnóstico, 61\% estavam no estadio I, 30\% no estadio II e 9\% no estadio III.

As pacientes foram entrevistadas por meio de entrevistas estruturadas e questionários contendo as seguintes variáveis psicológicas: percepção de controle, estresse e enfrentamento. A primeira fase foi realizada quando as pacientes voltavam para o check-up médico ou por telefone, aproximadamente três meses após o diagnóstico e a segunda fase foi realizada aproximadamente seis meses após o diagnóstico. A entrevista estruturada coletou informações demográficas e de percepções de controle, indagando: Quanto controle você acredita ter sobre os 
sintomas do seu câncer? Essa percepção foi coletada por meio da escala de Likert, indo do grau 1 (não muito) até o grau 4 (completamente). O segundo objetivo foi medir os sintomas de stress através da Lista Revisada de Sintomas-90. E, por último, o enfrentamento, que foi acessado por meio do Inventário de Estratégias de Enfrentamento.

Os resultados mostram que a interação do enfrentamento, a percepção de controle e as estratégias utilizadas pelas pacientes causam uma diminuição no stress. Além disso, se o stress é baixo, então as percepções de controle podem ser altas, o que leva a um aumento nas oportunidades de resolução dos problemas.

Epping-Jordan et al (1999) realizaram uma pesquisa com o objetivo de examinar: a disposição ao otimismo ou pessimismo; a disposição de monitorar o momento de realização dos exames em busca de pistas, sintomas de evitação e pensamentos intrusivos como resposta ao stress desencadeado pelo câncer, e o enfrentamento, como preditores de sintomas depressivos e ansiogênicos em mulheres com câncer de mama.

A hipótese formulada pelos autores coloca que a disposição ao pessimismo e ao monitoramento poderiam predizer ansiedade e depressão, e que esses últimos poderiam ser medidos por variáveis como a evitação, pensamentos intrusivos e enfrentamento. Este estudo contou com a participação de 80 mulheres com diagnóstico recente de câncer de mama. As participantes tinham uma média de idade de 54.8 anos; média de 14.4 anos de estudo; 69\% eram casadas ou viviam com um parceiro, $10 \%$ eram solteiras, $8 \%$ divorciadas e $13 \%$ viúvas.

Cada participante passou por uma entrevista estruturada que coletou dados demográficos, e respondeu a um questionário que acessava: variáveis psicológicas, informações sobre o diagnóstico e estágio do câncer que foram coletados por meio do prontuário médico; o otimismo, que foi medido pelo Teste de Orientação de Vida; a disposição ao automonitoramento foi acessada pela Escala de Estilo Comportamental de Miller; os sintomas de resposta ao stress (pensamentos intrusivos sobre o câncer e a recusa desses pensamentos), que foram medidos por meio da Escala de Impacto de Evento; o enfrentamento que foi acessado pelo Inventário de Estratégias de Enfrentamento e o stress emocional (sintomas de ansiedade e depressão), medido pela Lista Revisada de Sintomas-90. 
O quadro desenhado por essa pesquisa mostra que o momento do diagnóstico é o mais estressante de todos. E que mulheres com atitudes mais otimistas parecem estar mais protegidas do stress, e as mulheres mais pessimistas podem aumentar seu stress pela utilização de formas de enfrentamento desengajadas, que envolvem a autocrítica e o isolamento dos outros. As mulheres mais jovens também estão mais susceptíveis a altos índices de stress porque carregam mais pensamentos intrusivos em relação ao câncer do que as mais velhas. Finalmente, o enfrentamento parece desempenhar um papel restrito passados três meses do diagnóstico, porque poucas foram as mulheres que conseguiram utilizar-se de formas engajadas de enfrentamento, que são aquelas estratégias voltadas contra o agente causador do estresse, dentre elas, a busca de suporte social.

Em um estudo de 2000, realizado por Andsager e colaboradores, teve como objetivo analisar como as imagens visuais sobre o câncer de mama foram apresentadas em 11 revistas americanas voltadas ao público feminino, publicadas de 1970 a 1990. Para tanto foram utilizadas as seguintes categorias:

1) tópico do artigo;

2) principal papel feminino, subdividido em: a) sobrevivente - mulheres que sobreviveram ao câncer; b) paciente - mulheres que passaram pelo tratamento, bem como médicos e/ou membros da família e c) modelo uma mulher, narrador, ou outros, cujos nomes foram mantidos em sigilo, utilizados com o propósito de ilustrar as reportagens;

3) Idade dos rostos apresentados;

4) Raça e/ou etnia;

5) Tipo de corpo;

6) Ativa/Passiva: se a principal pessoa do sexo feminino estava engajada em alguma atividade, era então codificada como ativa. Fotos de mulheres representando emoções negativas ou ainda, sendo examinadas por um médico, foram codificadas como passivas.

Os comportamentos de subordinação foram utilizados para medir a culpa das pacientes. Para que isso fosse realizado utilizaram-se: comportamentos de supressão de partes do corpo, como cobrir a face com as mãos; comportamentos como estar de pé ou deitada e comportamentos de toque corporal. 
Os resultados indicam que os artigos que enfocam o câncer de mama cresceram durante os últimos anos, de 33 na década de 1970, para 89 na década de 1990. Esse estudo traz que as imagens das revistas estão, atualmente, mais voltadas a mostrar a mulher com câncer de mama e também, voltadas a incorporar mulheres mais velhas e de outras raças do que no passado. Entretanto, as mulheres fotografadas tendem a ser mais jovens e mais magras do que a média que recebe o diagnóstico de câncer de mama. Isso sugere que as ilustrações que acompanham o câncer de mama estão sendo construídas baseadas nos padrões de beleza valorizados socialmente. Além disso, as ilustrações demonstrando como fazer o auto-exame têm decrescido nos últimos trinta anos.

Portanto, o estudo citado sugere que as revistas têm avançado em muitos aspectos ao ilustrar a mulher com câncer de mama. Mas, ainda continuam também a depender do estereótipo de feminilidade presente em nossa sociedade.

Bergamasco (1999) realizou um estudo com mulheres com câncer de mama com o objetivo de compreender e descrever como a experiência do diagnóstico de câncer de mama é vivida pela mulher. Para que esse objetivo fosse alcançado foram entrevistadas 6 mulheres com as seguintes características: idade de 44 a 79 anos; 4 casadas, 2 viúvas; escolaridade até o primeiro grau completo; com número de filhos variando entre 2 a 3 vivos; todas eram donas de casa; todas seguiam o catolicismo; o nível sócio-econômico variou de baixo a médio; 2 mulheres haviam recebido o diagnóstico 4 ou 5 anos antes da entrevista e 4 mulheres haviam-no recebido o 1 ou 4 meses antes. Todas essas mulheres foram entrevistadas através do método biográfico com a utilização de narrativas e entrevistas em profundidade, nas quais as entrevistadas pudessem explicar e interpretar os eventos ocorridos. Todas essas entrevistas foram gravadas e transcritas na íntegra. A análise foi conduzida por meio do Interacionismo Interpretativo para interpretação de narrativas biográficas. Cada narrativa foi subdividida em pequenas unidades caracterizadas por pequenas frases chave. Estas foram interpretadas e os significados identificados foram conectados a outras frases chave dentro da estória. Sendo que cada interpretação foi analisada em relação à outra. Após essa análise, o material foi organizado com o objetivo de permitir ao leitor partilhar a experiência capturada (descrição densa). E foram identificados quatro temas que representam o significado simbólico do diagnóstico 
de câncer para a mulher, sendo eles: 1. descobrindo-se uma mulher que tem câncer; 2. querendo livrar-se da doença; 3. sendo ajudada para não desistir; 4.tentando adaptar-se à nova realidade.

Os resultados da pesquisa citados anteriormente mostram, segundo Bergamasco (1999), o quanto se descobrir com câncer remete principalmente ao sofrimento. Além disso, faz com que a mulher adquira uma nova identidade porque requer, entre outras coisas, que essa mulher aceite sua condição de portadora de câncer de mama e submeta-se ao tratamento. Assim, querendo livrar-se da doença, tenta fazer isso de forma rápida porque o desejo é resolver o câncer de forma eficaz. E aqui o suporte social adquire significado porque é por meio dele que a mulher sente-se ajudada para não desistir. Aliados a esse suporte, existem todas as transformações da própria identidade dessa mulher, que poderá apresentar novos sentimentos dependendo do modo como encara sua doença. Sendo que o resultado desses ajustamentos psicossociais é o que vai proporcionar à mulher a possibilidade de estabelecer novos propósitos de vida.

Silva \& Mamede (1998) ao investigarem as recordações do processo cirúrgico em mulheres mastectomizadas verificaram que esse ato despertou agressividade, nervosismo e insegurança.

Lazarus (1996, 1981) apud Gimenez (1997), observa que a avaliação cognitiva feita pelo sujeito ao se deparar com uma situação estressante pode ser de três tipos: “aquelas que se referem a dano, a ameaça ou a desafio”. (p.123), trazendo estes três tipos de avaliações para a mulher com câncer de mama ao ser admitida no hospital para passar pela cirurgia, podendo o dano estar ligado a sinais e sintoma, dentre eles uma possível deformação da mama; a ameaça pode estar ligada também à possibilidade da perda da mama e o desafio que seria talvez passar pela hospitalização e conseqüente cirurgia.

Os estudos apresentados mostram, em sua maioria, a importância das estratégias de enfrentamento utilizadas para lidar com o câncer de mama. Esses estudos também são um instrumento para a constatação de que outros momentos pelos quais uma mulher com câncer de mama têm de enfrentar necessitam ser investigados, como, por exemplo, o da entrada dessa mulher no hospital para se submeter à cirurgia por câncer de mama. 
Observando um dos resultados apresentados acima, encontrado por Bergamasco (1999), que foi o da mulher tentar livrar-se do câncer de mama de forma rápida, abre-se espaço para a reflexão de que a mulher ao se internar para passar pela cirurgia necessária ao tratamento do câncer de mama pode apresentar algum comportamento de pressa ou sentimento ansiogênico, porque a internação pode representar um encontro real dessa mulher com sua doença, e assim o desejo de fuga e suas próprias expressões podem se fazer mais presentes.

O momento escolhido para a presente pesquisa é o da entrada da mulher no hospital para se submeter à cirurgia por câncer de mama. Assim, apresentamos a definição de admissão hospitalar como a internação ou a entrada de uma pessoa em um hospital, sendo que este último tem como objetivo fornecer permanentemente assistência médica e de enfermagem, mas isso só ocorre quando há o consentimento da pessoa, ou familiar, ou responsável ou autoridade legal. Esse momento implica no afastamento dessa pessoa do ambiente que a cerca, e essa separação pode levar a pessoa a sentir medo e inutilidade (Sordi, 1988).

Ao assistir mulheres com câncer de mama no momento da admissão hospitalar necessária para a realização da mastectomia, percebo a necessidade dessas mulheres em procurar não entrar em contato com esse acontecimento, o que se expressa através, por exemplo, da verborragia e da vontade de que todo o processo que se desenvolverá dentro do ambiente hospitalar seja rápido e eficaz no sentido de trazer a cura.

A pressa e a verborragia, muitas vezes, parecem estar relacionadas ao sofrimento que representa na vida de uma mulher a entrada em um hospital para a realização da cirurgia por câncer de mama, pelo fato de poder representar inúmeras perdas.

Desde o momento em que iniciamos um contato mais próximo com mulheres com câncer de mama a serem mastectomizadas, no âmbito do ambiente hospitalar, o percebemos como um processo que necessita ser compreendido juntamente com os profissionais que as assistem dentro das características que compõem o ambiente hospitalar.

O hospital é uma instituição fechada que, por isso, possui características próprias. Dentre elas podem ser citadas seus movimentos de despersonalização 
(Angerami, 2001), infantilização (LeShan, 1992) e predominância da técnica em detrimento das relações humanas.

Dias (1997) ao investigar informações fornecidas a doentes de câncer de mama, utilizou o método do estudo de caso aliado à observação participante, durante dezoito meses, focando a relação doente-profissionais de saúde nas etapas cruciais do tratamento da participante do estudo. Os dados colhidos foram submetidos à análise de conteúdo temática. Os temas definidos a partir dessa análise foram: 1) o modelo de produção de cuidados; 2) a negociação entre os atores e as estratégias adotadas e 3) a informação ao longo da cadeia processual médica: o seu impacto no doente.

Os resultados mostraram que os cuidados prestados na cadeia processual médica são marcados por uma excessiva tecnologia e alta especialização da vocação médica, com a dependência do doente em relação ao cirurgião. Essa relação desigual também é verificada na relação dos profissionais de enfermagem e serviço social com os médicos, na qual os primeiros estão submetidos aos últimos. As informações fornecidas na cadeia processual médica mostraram-se incompletas e não contraditórias devido a movimentos de camuflagem e fuga dessas informações.

Valle (1986) em um de seus estudos intitulado: "Comportamentos psicológicos apresentados pelo paciente na sua admissão ao hospital”, teve como objetivos: verificar as etapas contidas na interação verbal enfermeiro-paciente e verificar o conteúdo desse relacionamento.

Participaram doze pacientes adultos, que eram capazes de estabelecer conversação, com idades entre 24 e 55 anos, todos internados de rotina nas clínicas de: Ortopedia (3 casos); Ginecologia-Obstetrícia (5 casos); Oftalmologia (2 casos); Cardiologia (1 caso), e Otorrinolaringologia (1 caso); e mais doze profissionais de saúde do sexo feminino (9 enfermeiras, 2 auxiliares de enfermagem e 1 atendente).

Para a coleta dos dados utilizou-se um protocolo para registro de relato cursivo das respostas emitidas pelos sujeitos durante o período em que eram observados. Essas sessões de observação iniciavam-se no momento em que um dos sujeitos emitia o primeiro comportamento verbal e terminavam quando o profissional de saúde afastava-se por cinco minutos. Dados referentes a pessoas ou situações que interferiram nos momentos de observação também foram anotados. 
As respostas foram então categorizadas nas seguintes etapas: aquecimento, explicação do procedimento, conteúdo verbal (temática) e desfecho. Os resultados mostram que o menor número de respostas oscilou entre a fase do aquecimento, apenas um pouco mais da metade dos profissionais a utilizou e o desfecho que $75 \%$ dos profissionais não utilizaram. Apenas $50 \%$ dos profissionais se preocuparam com as necessidades emocionais dos pacientes, contra 100\% de informações referentes ao ambiente físico da internação

Valle (1986) segue relatando que a entrada de uma pessoa em um hospital representa uma mudança extremamente brusca nos seus hábitos porque ela tem de deixar os seus entes queridos para dar entrada em um lugar que além de características físicas estranhas, é composto também por pessoas estranhas. Toda essa estranheza pode levar a pessoa admitida a ter dificuldades de adaptação, dificuldades que a fazem se posicionar como vítima ou como totalmente dissociada do que acontece ao seu redor, que são seus sintomas visíveis, mas que apenas mascaram sintomas latentes de medo, solidão e insegurança. E esses sentimentos podem trazer muito mais sofrimento à pessoa do que a própria patologia física. (Beland \& Passos, 1978; McCain, 1970).

Autores como Sordi (1988) e Timby (2001) atribuem à enfermagem a responsabilidade de realização da admissão hospitalar, essa compreendendo uma entrevista, o exame geral, (no qual são verificados os sinais vitais: temperatura, pressão arterial, pulso e respiração) e o histórico de enfermagem. Por isso, compreendem-se os resultados de Valle em seu estudo de 1986, de que faltam ainda, em alguns profissionais da área de enfermagem, habilidades de iniciar e finalizar um diálogo com aqueles que receberão seus cuidados, e também de se preocuparem com as necessidades emocionais de seus pacientes.

Compreendemos que os dados coletados em nossa pesquisa perpassam por toda essa ideologia que permeia a instituição hospitalar. Por isso, entendemos pertinente a discussão de como os profissionais realizaram as admissões hospitalares estudadas.

Nesse momento profissional, após leituras, discussões com outros profissionais da área da saúde e pela minha experiência enquanto psicóloga que presta assistência a mulheres com câncer de mama, coloca-se como problema desta 
pesquisa: O que significa para uma mulher se internar para se submeter à cirurgia por câncer de mama? Será que a mulher se sente ameaçada em sua feminilidade? Será que entrar no hospital para passar pela cirurgia significa estar retirando um pedaço doente do seu corpo para ficar livre da doença? A entrada no hospital desperta nessa mulher o lidar com a possibilidade de sua própria finitude?

Em relação aos profissionais indagam-se: Será que a rotina alucinante de trabalho que os leva a atender sempre mais pessoas no menor tempo possível influencia no modo como realizam o procedimento da admissão hospitalar? Como esses profissionais estarão voltados às necessidades emocionais e dialógicas daqueles que recebem seus cuidados, se até mesmo autores que direcionam seus estudos à área de enfermagem não chamam a atenção para elas?

De acordo com nosso entendimento a cirurgia por câncer de mama constituise num momento muito singular e carregado de representações, porque a mulher se vê sozinha e destituída até mesmo de muitos de seus pertences pessoais. Assim, entendemos ser a teoria das representações sociais a base de sustentação para podermos compreender que representações são essas. E a partir dessa compreensão poderemos entender também como essas mulheres enfrentaram esse momento da admissão hospitalar.

\subsection{Fundamentos da Teoria das Representações Sociais}

A teoria das representações sociais tem em Moscovici sua base primeira de criação e sustentação. Através de sua obra: "A Psicanálise, sua imagem e seu público" de 1961, Moscovici lança a pedra fundamental de difusão da teoria das representações sociais.

A partir da inquietação de que nem a sociologia nem a psicologia eram capazes de explicar os fenômenos coletivos humanos, Moscovici se viu então diante de uma lacuna; e a partir desse vazio formulou a teoria das representações sociais, cujo objetivo é explicar fenômenos da ordem humana a partir de uma perspectiva não só coletiva como busca a sociologia, nem só em uma perspectiva individual, almejada pela psicologia. 
Entretanto, por volta de 1970 é que a teoria das representações sociais encontra seu lugar e começa a ser empregada em pesquisas, utilizando tanto os métodos experimentais quanto os não experimentais. (Nóbrega, 1990).

Para uma maior compreensão do que vem a ser a teoria das representações sociais, abre-se espaço para uma descrição mais detalhada de seus dois pilares principais: a sociologia vista por Durkheim e a psicologia social.

Martins (1994) apresenta a sociologia como "um conjunto de conceitos de técnicas e de métodos de investigação produzidos para explicar a vida social" (p.8). Além disso, possui um projeto intelectual contraditório e tenso porque pode ser utilizada tanto a serviço daqueles que comandam como por aqueles que pertencem a movimentos revolucionários, e sempre, através de seu discurso, busca mudar a sociedade.

A definição de fato social postulada por Durkheim (1978) parece ser a mais adequada para que se possa entender as regras do método sociológico:

"O fato social não pode definir-se pela sua generalidade no interior da sociedade. Características distintivas do fato social: $1^{\circ}$ - a sua exterioridade em relação às consciências individuais; $2^{\circ}$ - a ação coerciva que exerce ou é suscetível de exercer sobre essas mesmas consciências...” (Durkheim, 1978, p.87).

Com o objetivo de exemplificar a primeira característica dos fatos sociais, que são objeto da sociologia, Durkheim (1978) cita os fiéis religiosos que ao nascerem já se deparam com as pré-estabelecidas práticas e crenças de sua vida religiosa.

A segunda característica do fato social, que trata da coerção que estamos submetidos socialmente é expressa por Durkheim (1978), por exemplo, quando não há a submissão às convenções sociais, que pode estar presente no modo como me visto, mas, se esse modo de me vestir não vai ao encontro do que está préestabelecido, o riso e o afastamento das outras pessoas em relação à minha maneira são esperados, que não deixam de ser efeitos de uma pena.

Durkheim (1978) finaliza sua apresentação do que vem a ser os fatos sociais afirmando que eles estão presentes onde há organização social definida. Assim, 
percebe-se que os fatos sociais são objeto de estudo da sociologia e que esses fatos sociais, pelas características apresentadas, são diferentes dos fatos sociais que as outras áreas do conhecimento utilizam como objeto de estudo.

A sociologia, portanto, lança seus "olhos” ao modo coletivo de viver em sociedade e, no como esse coletivo pode manejar o individual, diferentemente da psicologia social.

Segundo Rodrigues (1994), a psicologia social:"estuda as manifestações comportamentais suscitadas pela interação de uma pessoa com outras pessoas, ou pela mera expectativa de tal interação” (p.19).

A psicologia social tem na interação humana a sua unidade de análise, que para apreendê-la utiliza-se de métodos e técnicas científicas de pesquisa. Além disso, uma noção fundamental na conceituação de psicologia social é o denominado caráter latitudinal. Isto significa que este se caracteriza pelo papel que os fatores situacionais desempenham no comportamento social. (Rodrigues, 1994).

Rodrigues (1994) também ressalta a importância das características de personalidade para a explicação de determinados comportamentos. Isso significa que a psicologia social leva em conta o que ela denomina de fatores longitudinais, que seriam as "experiências passadas, fatores hereditários, características de personalidade”. (p.22)

Assim, a psicologia social pode ser definida, segundo Rodrigues (1994), como:

\footnotetext{
“...o estudo de manifestações comportamentais de caráter situacional suscitadas pela interação de uma pessoa com outras pessoas ou pela mera expectativa de tal interação, bem como dos estados internos que se inferem logicamente destas manifestações” (Rodrigues,1994, p.22).
}

\subsubsection{A Psicologia Social e a Sociologia}

A psicologia social e a sociologia são consideradas pela maioria dos autores, como possuindo um objeto formal distinto, mas tendo em comum objetos materiais, tais como atitudes, status, delinqüência, dentre outros, apesar das indagações a 
respeito dos mesmos objetos materiais, variarem muito quando formuladas por um sociólogo ou por um psicólogo. (Rodrigues, 1994).

Para ilustrar o que acabou de ser apresentado, Rodrigues (1994), cita como um dos exemplos o estudo da família. O sociólogo teria como interesse estudar como a autoridade dominante se expressa nessa família (equalitária, matriarcal, patriarcal). Enquanto que o psicólogo partiria dessas autoridades já estabelecidas para observar como essas posições estariam influenciando no comportamento de um dos membros dessa família quando comparado aos outros.

\subsubsection{Histórico da Psicologia Social}

Faz-se a opção, assim como Bernardes (2001), pela caracterização da psicologia social moderna como um fenômeno com características norte-americanas, apesar de suas raízes serem européias.

O resgate histórico da psicologia social implica, segundo Bernardes (2001, p. 21), em três pontos principais. São eles: a) o “repúdio positivista de Wundt”; b) “o longo passado e o curto presente da psicologia" e; c) “formas e formas de contar histórias da psicologia social”.

\subsubsection{O "repúdio positivista de Wundt"}

Wilheim Wundt (1832-1920) tinha três objetivos principais. O primeiro deles era o projeto de tornar a psicologia uma ciência independente. Isso foi conseguido através da criação do laboratório em psicologia em Leipzig (1879), onde criou uma psicologia experimental da mente, cujo objeto de estudo era a experiência imediata à consciência. Além disso, publicou em 1874, a primeira edição da revista Psicologia Fisiológica (Physiological Psychology) e em 1881, a revista Estudos Filosóficos (Philosophische Studien). 
O segundo objetivo de Wundt, formulado entre 1880 e 1900, era de uma metafísica científica ou uma filosofia científica, que foi conseguida por meio de três obras: uma de lógica; uma de ética e uma de sistemas filosóficos.

O terceiro objetivo do autor em questão era a criação de uma psicologia social, que ocorreu entre 1900 e 1920, com a elaboração de sua Volkerpsychologie (Psicologia do Povo ou Psicologia das Massas). Obra em 10 volumes, na qual ele se utilizou de objetos de estudo, como por exemplo, a linguagem e a cultura, entre outros.

\subsection{4 "O longo passado e o curto presente da psicologia"}

Parece que com Wundt, em 1879 é que se começa a pensar a recente história da psicologia para os psicólogos experimentais. Entretanto, para os psicólogos sociais experimentais, Auguste Comte é o pai da psicologia.

\subsection{5 "Formas e formas de contar histórias da psicologia social”}

Autores como Bernardes (2001) optaram por contar a história da psicologia social por meio de fatos, instituições e pesquisas publicadas.

Bernardes (2001) parte de uma publicação de 1949, intitulada: “The American Soldier" (O Soldado Americano, 1949), cujos temas de estudo estavam voltados a: 1) como os soldados viviam; 2) à eficácia das instruções recebidas no exército; 3) à comunicação de massa e mudança de atitudes.

O Tratado de Nuremberg teve sua influência nas pesquisas em psicologia social, pelo fato de divulgar os procedimentos éticos em pesquisas experimentais com seres humanos. (Bernardes, 2001).

A Escola de Frankfurt de Ciências Sociais, segundo Bernardes (2001), influenciou também a psicologia social. Isso ocorreu porque autores como Adorno, 
Horkheimer, Marcuse, entre outros, tiveram que imigrar, fundamentalmente pelo fato de Hitler ter fechado seus Institutos de Pesquisa.

O nazismo então, fez com que a intelectualidade alemã imigrasse para os Estados Unidos. Isso explica porque a psicologia social, na era moderna, tem raízes européias, apesar de ser um fenômeno americano. (Bernardes, 2001).

Outro ponto que marca o desenvolvimento da psicologia social é o quanto ela foi influenciada pelo positivismo. Esta forma de pensamento encontra-se, por exemplo, no livro de Schultz e Schultz (1994), citado por Bernardes (2001), cujo enfoque está em idéias e aplicações do método experimental.

\subsubsection{Psicologia Social no Brasil}

Bernardes (2001) afirma que entre as décadas de 1960 e 1970 reproduziu-se no Brasil, a psicologia social dos Estados Unidos. Aliás, esse mesmo autor, situa a obra de Rodrigues (1994) como um exemplo dessa reprodução americana.

Apesar da importação do modelo de psicologia norte-americano para o Brasil, ao final dos anos 70 do século passado, ocorreu o que se denominou de "a crise da Psicologia Social”, ou a "crise de referência”. Crise, que segundo Bernardes (2001) já era européia na década de 1960.

No Brasil a crise aflorou-se nos congressos de psicologia, o que resultou, em 1960, na Associação Latino-Americana de Psicologia Social (ALAPSO) e, mais tarde, em 1980, na Associação Brasileira de Psicologia Social (ABRAPSO). Esta última surge com o intuito de romper definitivamente com os laços norteamericanos.

Strey, et al (2001) afirmam que a psicologia social construída no Brasil no final de 1970 e, a partir de 1980, aponta para uma concepção histórico-social do ser humano, capaz de construir a sociedade e transformá-la, que ao “invés de considerar indivíduo e contexto social influenciando-se mutuamente, propõe a construção de um espaço de intersecção em que um implica o outro e vice-versa” (p.14). 
Oliveira e Werba (2001) explicam que, no Brasil, esse período (final de 1970 e início de 1980) também marcou o despertar do interesse pela teoria das representações sociais. Sendo que esse encontro histórico se deu porque a teoria das representações sociais desenvolveu-se simultaneamente ao desenvolvimento da psicologia social.

Atualmente, no Brasil, segundo Bernardes (2001), a psicologia social é capaz de produzir trabalhos em harmonia com o modo de ser e de agir do nosso povo, sem estar atrelada a teoria e métodos americanos.

\subsection{Teoria das Representações Sociais - RS}

A teoria das representações sociais na linha da psicologia social concebe o sujeito possuindo um eu, isto é, uma subjetividade, aliada a uma historicidade, que seria a somatória de todas as experiências vividas por esse sujeito, e por isso é denominada de teoria do senso comum. E esse senso comum tem sua importância porque é através dele que conceitos, significados e argumentações são determinados e aceitos por todos. (Moscovici apud Nóbrega, 1990).

Moscovici é um teórico que não possui como meta a definição de representação social, porque segundo Ogata (2000); Oliveira \& Werba (2001), isso levaria a um reducionismo até onde o conceito é capaz de chegar. O que se tem na literatura é uma tentativa de definição, dada por Moscovici em 1978: “ $a$ representação social é uma modalidade de conhecimento particular que tem por função a elaboração de comportamentos e a comunicação entre indivíduos” (p.26).

Autores como Oliveira \& Werba (2001) relatam que:

\footnotetext{
"as representações sociais são "teorias" sobre saberes populares e do senso comum, elaboradas e partilhadas coletivamente com a finalidade de construir e interpretar o real. Por serem dinâmicas, levam os indivíduos a produzir comportamentos e interações com o meio, ações que, sem dúvida, modificam os dois” (Oliveira \& Werba, 2001, p.105).
}

Para Jodelet (1986), a representação social designa um modo de pensamento social que compreende uma gama enorme de significados. Além disso, a autora ainda 
coloca cinco características fundamentais de representação: a) sempre é uma representação de um objeto; b) possui uma característica de imagem e uma propriedade de poder que pode interferir na percepção e no conceito em questão; c) remete a um significante; $d$ ) possui a capacidade de construção e, e) é autônoma e criativa.

Segundo Spink (1993, b), “as representações são essencialmente fenômenos sociais que, mesmo acessadas a partir do seu conteúdo cognitivo, têm de ser entendidos a partir do seu contexto de produção" (p.300).

As representações sociais são produzidas por meio do mundo simbólico, mais especificamente através da palavra comunicada. E estão estruturadas em três níveis: 1) cognitivo (refere-se ao acesso desigual das informações, interesses ou implicações dos sujeitos, necessidade de agir em relação aos outros); 2) formação da RS (objetivação e ancoragem); 3) edificação das condutas (opiniões, atitudes, estereótipos)” (Jodelet apud Nóbrega, 1990, p.9).

Moscovici apud Nóbrega (1990), situa as representações sociais como tendo duas funções principais: uma dessas funções é a de manter uma ordem que permite aos sujeitos se orientarem e dominarem o meio-ambiente social e material no qual estão inseridos. A outra função é de comunicação entre os membros de um grupo, comunicação essa que estabelece códigos com o objetivo de nominar e classificar de uma maneira singular partes do mundo desse grupo, bem como acontecimentos da vida individual e coletiva dessa comunidade.

Mais tarde, Abric apud Nóbrega (1990), contribuiu com mais duas funções às representações sociais. A função identitária, que assegura a especificidade e imagem positiva do grupo. E a função justificadora, que proporciona aos atores sociais reforçarem ou manterem comportamentos de diferenciação social ao se relacionarem entre grupos.

As representações sociais são formadas por meio de dois processos principais: de objetivação e amarração, postulados por Moscovici em 1961, sendo que o termo amarração, a partir do desenvolvimento da teoria, passou a ser denominado de ancoragem. E para que esses dois processos se efetivem, cada sujeito baseia-se em observações e testemunhos que se acumulam ao longo do tempo e em relação a um acontecimento. (Moscovici, 1978). 
Segundo Moscovici (1978), objetivar “é reabsorver um excesso de significações materializando-as (e adotando assim certa distância a seu respeito). É também transplantar para o nível de observação o que era apenas inferência ou símbolo... . Houve substituição do percebido pelo conhecido” (p.111-112).

Nóbrega (1990) afirma que a objetivação é um processo que tem como finalidade tornar o abstrato, concreto. É tornar o impalpável em palpável.

Moscovici (1978) relata que a naturalização e a classificação são operações essenciais da objetivação. Para desenvolver esses dois conceitos, Moscovici parte da idéia de como os indivíduos respondem aos estímulos. Esse responder implica que o sujeito se esforce de duas formas: a primeira forma compreende o transporte dos elementos do meio objetivo para o meio cognitivo, o que abre espaço para uma mudança de status e função desses elementos, que agora foram naturalizados e podem ser julgados pelo sujeito como uma realidade quase física. O segundo esforço, o de classificação, “coloca e organiza as partes do meio ambiente e, mediante seus cortes, introduz uma ordem que se adapte à ordem preexistente, atenuando assim o choque de toda e qualquer nova concepção” (p.113).

Spink (1993, b) explicita também que a objetivação implica em três etapas: primeiramente, a descontextualização da informação através de critérios normativos e culturais; em segundo lugar, a formação de um núcleo figurativo, a formação de uma estrutura conceitual; e finalmente, a "naturalização, ou seja, a transformação destas imagens em elementos da realidade” (p.306).

“A ancoragem está dialeticamente articulada à objetivação, para assegurar as três funções fundamentais da representação: incorporação do estranho ou do novo, interpretação da realidade e orientação dos comportamentos. A ancoragem permite a incorporação do que é desconhecido ou novo em uma rede de categorias usuais” (Nóbrega, 1990, p.20).

Spink (1993, b) afirma ainda que a ancoragem refere-se "à inserção do que é estranho no pensamento já constituído” (p.306). 
Pode-se afirmar, a partir das formulações apresentadas, que as representações sociais são um tipo de saber, cujos modos de elaboração podem ser estruturados em: 1) cognitivo; 2) formação das RS: objetivação e ancoragem e; 3) edificação das condutas: opiniões (difusão), atitudes (propagação) e estereótipos (propaganda). Somado a isso as funções das RS podem ser agrupadas em: 1) formação de condutas; 2) orientação na comunicação; 3) identitária e 4) justificadora. (Nóbrega, 1990).

De acordo com Farr (2000), Moscovici foi um teórico que modernizou a ciência social ao construir a teoria das representações sociais em substituição à teoria das representações coletivas (objeto de estudo de Durkheim) com o objetivo de fazer com que a ciência social se tornasse mais adequada ao mundo moderno, que possui uma pluralidade de construções e reconstruções de significados muito superiores quando comparada ao modo de vida social em que Durkheim realizou seus estudos. Isso significa que Moscovici, ao utilizar o termo representações sociais, busca dar conta de todas as mudanças pelas quais a sociedade atual passa.

Moscovici no prefácio do livro intitulado: “Textos em representações sociais” (Guareschi \& Jovchelovitch, 2000) discute as novas possibilidades abertas pela teoria das representações sociais, colocando que o sujeito constrói o mundo como constrói a si mesmo na relação e atividade que estabelece com o mundo e consigo mesmo. Por isso, a importância de existência da sustentação tanto dos pressupostos da psicologia quanto dos da sociologia. Mas, a teoria das representações sociais busca ir mais além, almeja uma síntese teórica conjugando as dimensões cognitivas, afetivas e sociais. As representações sociais envolvem a cognição porque se referem à construção de saberes sociais. Estes saberes evocam imaginação e conseqüentemente afetos e emoções. Sendo que as representações sociais encontramse na base da realidade social, na qual estão presentes a cognição e os afetos.

Farr (2000) situa a teoria das representações sociais como uma forma sociológica de psicologia social. Em relação a essa afirmação, Bernardes (2001), coloca que Farr a faz porque é uma forma de compreender os fenômenos resultantes da relação entre o individual e o coletivo, mas, sem reduzir a explicação desses mesmos fenômenos como provenientes do indivíduo ou do social. Farr continua, afirmando que a teoria das representações sociais de Moscovici, desde sua 
formulação, foi uma crítica ao modo individualizante da psicologia social estudar os fenômenos da ordem humana.

A teoria das representações sociais tem tido uma enorme penetração nos campos de estudos que envolvem a saúde e a doença como tema. Oliveira \& Rodrigues (2001) mostram que 31,7\% da produção brasileira na área da saúde entre os anos de 1988 e 1997 utilizaram a teoria das representações sociais na linha da psicologia social. Além disso, Ogata (2000) discute a importância dos estudos de representações sociais na área da saúde, afirmando que essa importância assenta-se na preocupação com a subjetividade do dia-a-dia e conseqüentes relações envolvidas.

De acordo com Spink (1995) as representações sociais podem ser enfocadas como produto e como processo. Esses dois enfoques determinam o método e o modo de compreensão de determinado fenômeno. Enquanto produto, as representações sociais "emergem como pensamento constituído ou campo estruturado. Nessa perspectiva a pesquisa visa depreender os elementos constitutivos das representações” (p. 90). Mas, essas representações sempre devem ser analisadas de acordo com as condições em que foram produzidas. Os estudos que seguem esse enfoque tendem a utilizar métodos e técnicas das abordagens qualitativas de pesquisa (Castro, 1995; Sato, 1995; Guareschi, 1995).

As pesquisas que seguem o enfoque das representações sociais enquanto processo, consideram que essas "emergem como pensamento constituinte ou núcleos estruturantes. Nessa perspectiva a pesquisa volta-se à compreensão da elaboração $e$ transformação das representações sob a força das determinações sociais, ou à compreensão do funcionamento e eficácia das representações na interação social” (Spink, 1995, p. 91). Esses estudos tendem a examinar os processos de objetivação e ancoragem na elaboração cognitiva ou ainda, a formulação de hipóteses sobre os núcleos centrais das cognições de uma representação, estes últimos são desenvolvidos pelo Grupo do Midi, constituído por pesquisadores do Sul da França, e no Brasil, Celso Pereira de Sá aparece como um dos representantes que pesquisa as representações sociais buscando compreendê-las a partir de seus núcleos centrais e de seus elementos periféricos, como por exemplo, em: “A representação social da economia brasileira antes e depois do plano real” (1998) e “Socialização do saber acadêmico: uma pesquisa sobre a representação social à luz da teoria do núcleo 
central” (2002). São estudos que preferencialmente utilizam métodos e técnicas experimentais.

A escolha de realização de um estudo qualitativo nos apresenta a possibilidade de compreensão das representações sociais de mulheres admitidas para serem submetidas à cirurgia por câncer de mama, permeada pelo enfoque dessas representações enquanto produto.

\subsection{Hospital: espaço de acolhimento e cura?}

Foucault (1979) retrata o nascimento do hospital afirmando que ele existe há milênios, mas, no século XVIII é que efetivamente descobriu-se que os hospitais não curavam como deviam.

Antes do século XVIII, o hospital primava pelo atendimento aos pobres, que ao mesmo tempo os assistia e também os separava e excluía. Os pobres representavam uma ameaça de contágio aos outros, assim o hospital servia como um lugar para recolher os pobres e proteger os outros do perigo dos primeiros (Foucault, 1979).

O hospital também era conhecido como o lugar onde as pessoas morriam. Sendo que as pessoas que lá trabalhavam não tinham como meta a cura do doente, mas sim sua salvação própria. Isto significa dizer que trabalhar em um hospital era sinônimo de caridade e de indulgência (Foucault, 1979).

Ainda segundo Foucault (1979), o hospital passou a ser medicalizado a partir da anulação de suas desordens. Aliás, o ponto inicial da reforma hospitalar foi o hospital marítimo, pelo fato de ser um ponto de desordem econômica, isto é, o traficante escondia objetos, fazia-se de doente e era levado ao hospital imediatamente após o desembarque. E esse “esconder” livrava o traficante da fiscalização alfandegária, por isso, foi instaurado o primeiro regulamento do hospital, datado do século XVII: a fiscalização dos cofres que boticários, médicos e marinheiros possuíam nos hospitais. Dessa forma, percebe-se que através da instauração do poder disciplinar, uma nova técnica de gestão dos homens foi gerida. 
Sá (1993) coloca o hospital como o local onde doentes são acolhidos e doenças são tratadas, juntamente com profissionais de saúde tentando realizar suas funções em meio às limitações subjetivas e objetivas da instituição hospitalar.

A função do hospital está pautada em garantir ao paciente segurança de diagnóstico, tratamento de qualidade e, para que a recuperação se dê de forma globalizada há que se levar em conta os aspectos psicológicos desse indivíduo que se encontra hospitalizado (Sá, 1993).

Toda instituição possui o que Goffman (1992) denomina de "tendências de fechamento" (p.16), que se caracterizam pela tomada de parte do interesse e do tempo daqueles que fazem parte dela e, pela condição de prover a esses participantes modos de ser e agir peculiares a ela.

As instituições podem ser agrupadas em torno de três aspectos fundamentais. O primeiro deles é que a vida tem de ser vivida sempre num mesmo lugar e submetida a uma autoridade única. O segundo aspecto é que as atividades diárias são realizadas junto a um grupo de pessoas, que são tratadas da mesma maneira e com a obrigação da realização das mesmas coisas. E o terceiro aspecto é a realização de todas as atividades diárias em horários estabelecidos rigorosamente. Assim, são atividades obrigatórias organizadas com racionalidade a fim de que os objetivos das instituições possam ser alcançados (Goffman, 1992).

Segundo Carapinheiro (1993), a instituição hospitalar é marcada por uma simbologia característica de um mundo fechado, no qual a doença está presente. Essa simbologia institui segregações físicas e simbólicas.

A cor dos uniformes e a posição das salas dos profissionais são alguns exemplos das segregações que existem dentro do hospital. A cor branca implica em hierarquias que no geral dividem de forma ampla profissionais da saúde, doentes e profissionais da limpeza (Carapinheiro, 1993).

Ao doente fica delimitado um pequeno espaço, que são a cama e a mesinha de cabeceira. Geralmente sobre a mesinha ficam expostos alguns pertences pessoais seus como santos de sua devoção, fotos de entes queridos, dentre outros, que são elementos simbólicos representantes do seu pequeno universo privado que resistem ao despojamento (Carapinheiro, 1993). 
Os elementos simbólicos que cercam o doente tendem a reduzi-lo a apenas um corpo, que é vulnerável porque possui a sua volta equipamentos para protegê-lo do perigo de morte, como o oxigênio, e, ao mesmo tempo é um corpo acessível porque está colocado em uma cama que não tem fronteiras para ser acessada (Carapinheiro, 1993).

LeShan (1992) afirma que o hospital é uma organização dirigida por administradores, caracterizada pela venda, dentre outros, de procedimentos que estejam relacionados às doenças.

Foucault (1998) também apresenta o hospital como um local onde há poder e saber, que estão sempre intrinsecamente relacionados porque as relações de poder implicam na constituição de campos de saberes e, por outro lado, o saber possibilita o exercício do poder.

Os profissionais que atuam no hospital estão a todo o momento submetidos a pressões da própria instituição hospitalar, no sentido de que aceitem suas regras como corretas e, em contrapartida, considerem errados os usuários que não concordem com elas. Isso faz com que o cuidado fique prejudicado (LeShan 1992) porque os profissionais têm seus papéis submetidos ao conflito presente entre os interesses da direção hospitalar e as necessidades das pessoas que estão sob seus cuidados. E, talvez esse seja um dos fatores estressantes para os profissionais que trabalham dentro de hospitais.

A instituição hospitalar comporta ainda a dualidade de interesses entre o corpo médico e o corpo administrativo, no sentido de que o primeiro visa as atividades curativas, e, por outro lado a instituição hospitalar preconiza a realização de atividades de acolhimento e abrigo de doentes, atividades estas que apenas reproduzem o primeiro modelo de gestão hospitalar formulado, que possuía como prioridade o acolhimento dos pobres (Foucault, 1979; Carapinheiro, 1993).

O hospital também coloca situações novas a aqueles que permanecem dentro dele por um período para receberem cuidados. Sua inerente rotina provoca uma privação de todos os referenciais de adulto, conseqüentemente é um cuidado que infantiliza, desperta passividade e dependência, que são estratégias capazes de produzir o chamado paciente bom (LeShan, 1992). 
Os efeitos do processo de infantilização provocado pelo hospital podem acarretar conseqüências sérias aos seus usuários. Dentre eles, o sentimento de que não se é mais do que um objeto, uma máquina que precisa ser consertada. Isso pode levar o usuário a ter dificuldades em lutar por sua recuperação. Entretanto, uma pessoa infantilizada é confortante para a equipe (LeShan, 1992) porque ela não leva os profissionais a entrarem em contato com seus próprios sentimentos e, possibilita também, que os procedimentos possam ser realizados no tempo em que são considerados corretos, mas, que muitas vezes não é o tempo que aquele que está internado necessita.

Além de optarmos por trabalhar com as representações sociais enquanto produto, que podem ter sua construção influenciada pelas características que compõem o ambiente hospitalar, compreendemos ainda que elas estão intimamente ligadas aos modos de enfrentamento que os sujeitos utilizam para ultrapassar momentos estressantes, como é o caso da admissão hospitalar para a realização da cirurgia por câncer de mama.

\subsection{Teoria do Enfrentamento}

Queiroz (1993) define enfrentamento enquanto esforço ou esforços, provenientes do sujeito, com vistas à realização de certos objetivos.

O termo enfrentamento é traduzido do inglês coping, que na língua inglesa, segundo Gimenez (1997), é utilizado para designar comportamentos ou ações necessárias para vivenciar eventos problemáticos ou ameaçadores.

As abordagens tradicionais do enfrentamento provêm tanto da literatura que trata da experimentação animal quanto da literatura que aborda a psicologia do ego, mais especificamente a psicanálise. Os experimentos com animais são fortemente influenciados pelo pensamento de Darwin, que define enfrentamento como os atos que controlam condições ambientais aversivas. E a psicanálise, que define enfrentamento como pensamentos realísticos e flexíveis utilizados pelas pessoas para solucionar problemas que, conseqüentemente reduzem o estresse. Portanto, este modelo, ao ser comparado ao modelo Darwiniano, não ignora a existência do comportamento, este é sim tratado como algo menos importante que a cognição. 
A história da psicologia apresenta o termo enfrentamento como diretamente ligado à adaptação do ser humano ao seu cotidiano. Sendo que atualmente, ainda na psicologia, tem-se dificuldades em definir, mensurar e saber a função do enfrentamento. (Gimenez, 1997).

Mas, parece existir consenso que enfrentamento e adaptação são termos distintos. A "adaptação é um conceito mais amplo que abrange rotinas, formas automáticas de comportamento, enquanto o enfrentamento sempre supõe algum nível de estresse” (Gimenez, 1997, p.115).

Lazarus e Folkman (1984) definem o enfrentamento como esforços cognitivos e comportamentais do sujeito, utilizados com o intuito de manejar demandas estressantes tanto internas quanto externas. Definição que os mesmos contestam ao desenvolverem a teoria do enfrentamento enquanto processo.

Gimenez (1997), apresenta conclusões de várias definições de enfrentamento encontradas na literatura. São elas:

"A maioria das definições compartilham a idéia de que as pessoas ativamente respondem às exigências impostas a elas.

Todas compartilham a noção de que o enfrentamento corresponde à ação ou aos comportamentos que as pessoas apresentam para lidar com situações difíceis e estressantes.

A maioria das definições entende o enfrentamento como inseparável tanto do estresse experienciado pela pessoa no seu contexto de vida, ou seja, demanda externa, quanto dos estados emocionais relacionados à sua vida emocional, ou seja, demandas internas.

Todas as definições implicam na compreensão da natureza do enfrentamento, ou seja, do referencial teórico que oferece subsídio para a sua compreensão" (Gimenez, 1997, p.116).

\subsubsection{Enfrentamento versus comportamentos adaptativos automáticos}

A diferença existente entre enfrentamento e respostas automáticas não é sempre palpável. Não há formas de se afirmar até que momento o sujeito utiliza-se 
de respostas automáticas e/ou do enfrentamento. Há indícios de que numa experiência desconhecida, o sujeito tende a utilizar-se do enfrentamento porque a situação lhe pede e demanda esforço dele, entretanto, com a repetição da exposição do sujeito a essa mesma situação, parece que as respostas emitidas tornam-se automáticas e não envolve mais esforço por parte do sujeito. Assim, nem todos os processos adaptativos são de enfrentamento. O enfrentamento é uma parte das atividades adaptativas, que envolve esforço para manejar as demandas de estresse. (Lazarus e Folkman, 1984).

Autores como Lazarus e Folkman (1984) afirmam que a definição de enfrentamento como ligada a esforços do sujeito para manejar demandas estressantes apresenta limitações. A primeira delas é tratar o enfrentamento como uma resposta pronta e não enquanto um processo. Além disso, é uma definição que rejeita a confusão presente no termo enfrentamento, como sinônimo de todos os esforços do sujeito para manejar eventos estressantes de sua vida diária. Esforços tanto comportamentais quanto cognitivos. E, ao se usar da palavra manejo está-se possibilitando não a supremacia do enfrentamento por si só, mas a supremacia do meio ambiente porque esta implica a submissão do sujeito a um evento.

Ao se fazer a opção por descrever de que formas as mulheres enfrentam o momento da internação para a realização da cirurgia por câncer de mama, faz-se necessária também explicitar que nossa escolha é fazer essa descrição entendendo o enfrentamento como um processo. Isso porque a literatura coloca que se pode entender o enfrentamento como um estilo de personalidade do sujeito, o que é sustentado pelo referencial teórico psicanalítico. E ainda o enfrentamento pode ser analisado como um processo, entendido aqui como sendo algo mutável no tempo e em acordo com as mudanças do contexto onde o fenômeno em investigação ocorre. (Gimenez, 1997). Dessa forma, esse segundo modo de entender o enfrentamento vai ao encontro também do referencial teórico escolhido para embasar esta pesquisa, referencial este que concebe os fenômenos como mutáveis e moldados também pelo contexto onde acontecem. 


\subsubsection{Enfrentamento como processo}

A abordagem do enfrentamento enquanto processo possui três características. A primeira delas implica em observações do sujeito participante da pesquisa com o objetivo de captar o que naquele momento ele pensa ou faz, em oposição ao que esse mesmo indivíduo normalmente faz, poderia fazer ou deveria fazer. A segunda característica define que pensamentos e comportamentos do sujeito devem ser analisados em consonância com o contexto em que ele estiver inserido, porque pensamentos e ações são sempre direcionados a condições particulares. E a terceira característica do enfrentamento enquanto processo é a mudança nos pensamentos e atos de enfrentamento, que devem ocorrer no sujeito como forma de enfrentar momentos estressantes. O enfrentamento, nesse sentido, é um processo de mudança no qual o sujeito deve, em certos momentos, confiar mais arduamente numa forma de enfrentamento, ou seja, utilizar estratégias defensivas, e, em outros momentos utilizar estratégias de resolução de problemas, como formas de se relacionar com as mudanças que ocorrem ao seu redor. (Lazarus e Folkman, 1984).

As respostas de enfrentamento para lidar com eventos estressantes são inúmeras. Entretanto, Gimenez (1997) relata que:

"segundo a abordagem de enfrentamento proposta por Lazarus e colaboradores, duas modalidades de enfrentamento podem ser diferenciadas: aquelas que fundamentalmente permitem ação direta sobre o eи ou o ambiente e aquelas que funcionam primordialmente por meio de processos intrapsíquicos” (Gimenez, 1997, p.126).

Para ilustrar essas duas modalidades de enfrentamento, Gimenez (1997) apresenta:

“... a mulher que acabou de receber a notícia do diagnóstico de câncer da mama pode simultaneamente estar realizando exames complementares, acertando detalhes para internação hospitalar para a realização da mastectomia e, ao mesmo tempo, procurando distrair-se para não "pensar" nas conseqüências da cirurgia ou procurando, ainda “acreditar” que, no último momento, não será preciso retirar a mama. 
Assim houve uma complementaridade de estratégias de enfrentamento: umas permitindo que a ação direta e intervenção sobre o câncer e outras permitindo que a mulher não se desesperasse diante da situação...” (Gimenez, 1997, p.127).

As funções do enfrentamento vêm sendo pesquisadas por teóricos que

“... sugerem que as funções do enfrentamento são entendidas, de modo geral, como cinco funções principais. A primeira delas consiste em reduzir as condições ambientais que causam dano a aumentar as possibilidades de recuperação; a segunda refere-se a tolerar ou adaptarse a eventos ou realidades negativas; a terceira diz respeito a manter uma auto-imagem positiva diante da adversidade; a quarta função consiste em manter o equilíbrio emocional, enquanto a quinta consiste em a pessoa continuar relacionamentos satisfatórios com os outros" (Cohen e Lazarus, 1979 apud Gimenez, 1997, p.133).

Entende-se um desenvolvimento no conceito do termo enfrentamento deslocando-o principalmente da biologia para a psicologia. Isso significa primar o quanto cada sujeito é capaz de utilizar seus recursos internos e externos para lidar com eventos estressantes. Além disso, implica em subjetividade e, conseqüentemente, apenas indo até determinado contexto e entrevistando quem o compõe é que se é capaz de relatar que formas de enfrentamento esses sujeitos utilizam.

O resultado final de todo o processo que envolve o enfrentamento é levar o sujeito a assumir sua vida social da forma como era anterior ao estresse que sofreu, isto é, fazer do sujeito uma pessoa adaptada psicossocialmente (Gimenez, 1997).

E aqui se fecha o ciclo proposto também pelo referencial teórico das representações sociais, no qual o eu e o contexto estão em constante construção. E esse sujeito é que selecionará suas próprias formas de enfrentamento, dependendo da situação estressante a que estiver exposto.

Diante da opção de compreender o momento da admissão hospitalar necessária para a realização da cirurgia por câncer de mama através da teoria das 
representações sociais e da teoria do enfrentamento, faz-se necessária a apresentação de nossos pressupostos.

As representações sociais sobre a admissão hospitalar necessária para a realização da cirurgia por câncer de mama têm relação com as escolhas de enfrentamento utilizadas por essas mulheres.

A ansiedade é percebida nas mulheres que necessitam enfrentar esse momento como forma de enfrentamento contra a angústia proveniente da admissão hospitalar e da presença do câncer também. 


\section{OBJETIVOS}

\section{Objetivo Geral}

Compreender as representações sociais de mulheres sobre o câncer de mama e as estratégias de enfrentamento no momento da admissão hospitalar necessária para a realização da cirurgia por câncer de mama.

\section{Objetivos Específicos}

Identificar os significados atribuídos pelas mulheres sobre o câncer de mama e a relação que fazem com o tratamento cirúrgico, no momento da admissão hospitalar;

Descrever os modos de enfrentamento que cada mulher com câncer de mama se utiliza no momento da admissão hospitalar para tratamento cirúrgico;

Compreender o modo como são assistidas as mulheres com câncer de mama pelos profissionais da enfermagem, no momento da admissão hospitalar, como fator facilitador ou obstaculizante para as estratégias de enfrentamento. 


\section{MÉTODO}

\subsection{Tipo de estudo}

O estudo realizado foi predominantemente qualitativo-interpretativo. Nossa preocupação central foi descrever em profundidade e interpretar à luz da teoria das representações sociais o que é que cada mulher entrevistada atribuiu como significado de estar entrando no hospital para se submeter à cirurgia por câncer de mama.

Debus (1994) afirma que o enfoque qualitativo proporciona uma compreensão aprofundada dos fenômenos, além de ter um caráter interpretativo ao invés de descritivo.

Segundo Sandelowski (1993), a pesquisa qualitativa pode ser comparada à arte, a partir do momento em que seus resultados podem ser vistos como uma representação, que é tão rica em detalhes como uma obra de arte ao ser concebida por um artista.

As raízes históricas da investigação qualitativa assentam-se em várias disciplinas, que segundo Debus (1994) seriam: a crítica literária, as ciências sociais e a teoria psicanalítica. O mesmo autor afirma também que as técnicas de entrevistas da investigação qualitativa surgiram predominantemente da teoria psicanalítica.

Bogdan e Biklen (1994) postulam cinco características para a investigação qualitativa: 
a- os dados são coletados onde o fenômeno a ser pesquisado acontece, além do pesquisador ser o instrumento principal porque ele é quem analisará os dados;

b- a investigação qualitativa preocupa-se com a descrição, já que os dados recolhidos apresentam-se predominantemente na forma de palavras, o que dá o caráter de profundidade ao estudo;

c- o interesse do investigador qualitativo está centrado no que levou à formação de determinada realidade ou produto, e não neste último;

d- os dados são analisados de forma indutiva, ou seja, parte-se do individual para se chegar ao geral;

e- a abordagem qualitativa concebe o significado como de extrema importância valorizando muito a perspectiva do outro.

\subsection{Contexto do estudo}

\subsubsection{A enfermaria estudada}

O fenômeno que nos propomos estudar foi o da admissão hospitalar necessária para a realização da cirurgia por câncer de mama. Para tanto, escolhemos um dos hospitais-escola de Ribeirão Preto, SP, e, mais especificamente a enfermaria de ginecologia e obstetrícia deste mesmo hospital.

A clínica estudada é subdividida nas alas A e B. Na primeira concentram-se mulheres que necessitam de cuidados na área da obstetrícia e, na ala B permanecem mulheres que inspiram cuidados na área de ginecologia.

As alas A e B contam juntas com 58 leitos, em cada uma delas há um posto de enfermagem, onde diariamente trabalham em média 25 profissionais da área da saúde.

As mulheres que chegam para serem admitidas na ala $B$, que é a área de ginecologia e onde os dados desta pesquisa foram coletados, permanecem aguardando para serem levadas aos quartos numa sala de espera, que contém uma televisão e algumas cadeiras. 
Todos os quartos onde as mulheres que participaram deste estudo foram admitidas apresentaram características parecidas, que geralmente continham: 1) seis camas; 2) seis criados mudos para acomodar os pertences das mulheres internadas; 3) uma televisão com mesa para acondicioná-la; 4) uma mesa maior com duas cadeiras; 5) um banheiro; 6) três janelas; 7) cinco kits de oxigênio; 8) seis suportes para soro; 9) um hamper; 10) um lixo pequeno e, 9) um ventilador pequeno. Todos esses quartos eram bem iluminados e arejados. Portanto, nessa enfermaria há todas as condições físicas adequadas para o acolhimento de mulheres que dela necessitem para receberem cuidados.

\subsubsection{A admissão hospitalar na enfermaria de ginecologia e obstetrícia: contexto do estudo}

A mulher que chega ao hospital para ser submetida à cirurgia por câncer de mama é encaminhada e acompanhada por um profissional até uma sala de espera dentro da enfermaria de ginecologia e obstetrícia. Essa sala contém uma televisão, várias cadeiras e revistas. Nesse espaço permanecem as mulheres que entraram no hospital e possíveis acompanhantes, até que um dos profissionais da enfermagem ou da medicina as chamem. Esse profissional dirige-se até a porta da sala de espera, chama-a e leva-a para o leito previamente definido, aqui também o(s) acompanhante(s) pode(m) ir com ela.

Chegando ao leito, a mulher é convidada a colocar seus pertences no criado que fica ao lado do leito onde permanecerá durante o período de hospitalização, e a ela é dito que ali será seu lugar. Ao se sentar lhe são feitas perguntas referentes a possíveis doenças crônicas e remédios que toma diariamente; o motivo de ter procurado ajuda médica; se ela está consciente do que acontecerá com ela e possíveis alergias a medicamentos. A mulher tem também seu peso e altura verificados, além da verificação dos sinais vitais (pressão arterial, pulso e temperatura) e da coleta de sangue. E nesse momento, é indagado tanto à mulher quanto ao ou aos acompanhantes se eles receberam o "folheto de orientações ao cliente e familiares", 
que é entregue na entrada do hospital, se sim é investigado se há dúvidas, e, se não foi lido por algum motivo, é então explicado pelo profissional todas as informações que ele contém. Essas informações são referentes a: o que é necessário trazer ao hospital; seguir as refeições que lhe serão trazidas e, apenas se alimentar delas; não beber bebidas alcoólicas e, se fumar, procurar os fumódromos; trazer consigo medicamentos que toma diariamente comunicando sempre a equipe de enfermagem; a necessidade de cinco doadores de sangue; os horários de visita e como elas acontecem; a possibilidade de receber a visita de religiosos; a existência de uma capela dentro do hospital; informações sobre a alta, que seriam aguardar as orientações, a importância de estar com o cartão consigo porque o retorno é agendado nele, e, se necessário um atestado, avisar com antecedência; há também números de telefones que podem ser utilizados para se obter notícias da pessoa internada. Se o ou o(s) acompanhante(s) não se despediu ou despediram, ele ou eles são convidados a acompanhar o profissional que admitiu a mulher que será submetida a algum procedimento cirúrgico.

\subsection{Universo empírico}

Os participantes deste estudo foram mulheres com diagnóstico de câncer de mama e profissionais de enfermagem em interação no momento da admissão hospitalar necessária para a realização da cirurgia por câncer de mama.

\subsection{Amostra}

Os sujeitos da pesquisa foram mulheres que se internaram para passar pela cirurgia por câncer de mama e os principais profissionais responsáveis por suas admissões hospitalares necessárias para a realização da cirurgia por câncer de mama. O tamanho da amostra foi determinado pelo critério de saturação dos dados, ou seja, 
foram realizadas entrevistas até o momento em que os dados coletados começaram a se repetir.

Os dados apresentaram saturação após a realização de dez entrevistas, quando então concluímos a realização da coleta de dados, por entendermos que possuíamos dados suficientes para atingirmos os objetivos desta pesquisa.

\subsection{A entrada no campo}

A entrada na enfermaria de ginecologia e obstetrícia de um dos hospitaisescola de Ribeirão Preto, SP, onde são recebidas mulheres a serem submetidas à cirurgia por câncer de mama, local onde os dados desta pesquisa foram coletados, ocorreu em Março de 2002, quando iniciei um estágio como bolsista do Programa de Aperfeiçoamento de Ensino (PAE), na disciplina de Ginecologia e Obstetrícia ministrada aos alunos do último ano do curso de enfermagem da Escola de Enfermagem de Ribeirão Preto.

O Programa de Aperfeiçoamento de Ensino (PAE) foi instituído na Universidade de São Paulo (USP) em 1994, e implementado na Escola de Enfermagem de Ribeirão Preto (EERP), é composto pela tríade pós-graduandos, docentes e alunos de graduação. Esse programa tem como finalidade fazer com que o aluno de pós-graduação se envolva e auxilie um professor que esteja ligado, entre outras atividades, ao ensino de graduação.

Aos alunos participantes é permitido: a aplicação dos conhecimentos teóricos adquiridos nas disciplinas cursadas na pós-graduação; a possibilidade de se capacitar pedagogicamente e se aperfeiçoar didaticamente; a troca de experiências e conhecimentos; e por último a oportunidade de divulgar o trabalho desenvolvido no PAE aos alunos ingressantes na pós-graduação.

Estando atenta à importância da admissão hospitalar, propus atuar junto aos alunos de graduação em enfermagem com o intuito de atingir os seguintes objetivos:

- orientar os alunos de enfermagem para ouvir as mulheres que eram admitidas tentando: identificar as necessidades psicológicas delas; 
- estabelecer um diálogo face a face com a mulher que estava se internando;

- decodificar a linguagem hospitalar;

- esclarecer aos alunos o significado simbólico de comportamentos ou verbalizações das mulheres que estavam dando entrada no hospital.

Esse estágio finalizou em junho de 2002. Em seguida, no período de Julho a Setembro permaneci realizando o estudo piloto, restringindo as observações e entrevistas apenas com mulheres que eram admitidas para passar pela cirurgia por câncer de mama. Nesse espaço de tempo, verificamos se os instrumentos de observação e as questões norteadoras da entrevista eram capazes de direcionar nosso olhar para nosso objeto de pesquisa: o significado da admissão hospitalar para uma mulher que tem que passar pela cirurgia por câncer de mama.

Definidas as formas e os conteúdos tanto dos instrumentos de observação quanto das entrevistas, iniciamos a utilização do gravador no momento das entrevistas após a autorização das entrevistadas, que tinham como garantia que os dados gravados não seriam utilizados na versão final do estudo, mas sim, para que tivéssemos condições de chegar à construção de questões com a maior capacidade possível de acessar o que é para uma mulher chegar ao hospital sabendo que vai ser submetida a uma cirurgia por câncer de mama.

A utilização do gravador evidenciou que vários ajustes eram necessários, os quais começaram após a análise das quatro primeiras entrevistas gravadas. Inicialmente constatamos que o som emitido pelo gravador não era audível perfeitamente, fizemos então a opção de trocar o gravador. Em seguida, verificamos: que o local das entrevistas teria que ser mais reservado porque o barulho ao fundo impedia a compreensão das falas já gravadas; a posição do gravador teria que ser mudada para que o microfone pudesse captar melhor o que se falava e o volume do gravador teria que ser maior. A partir da análise das entrevistas cinco e seis, constatamos que o modo de condução das entrevistas teria que ser mudado. As entrevistas estavam longas e muito voltadas para os aspectos gerais do câncer de mama e não direcionadas para o nosso objeto de estudo. 


\subsection{Instrumentos}

Permanecendo nesta enfermaria de ginecologia e obstetrícia no período de Março a Junho de 2002 tive a possibilidade de observar de forma não sistemática o modo como são realizadas as admissões hospitalares na enfermaria em questão. Isso nos forneceu subsídios práticos para que pudéssemos construir os instrumentos de observação (ANEXOS C e E), utilizados com os principais profissionais responsáveis pela realização das admissões hospitalares das mulheres que ali chegavam para ser internadas, bem como para a observação destas últimas.

Além das observações assistemáticas, que proporcionaram a construção dos instrumentos de observação desta pesquisa, o período de Março a Junho de 2002 foi de extrema importância também porque através de conversas informais com as mulheres que ali chegavam para serem internadas, pudemos verificar se as questões norteadoras definidas previamente quando na construção do projeto de pesquisa respondiam aos objetivos do estudo.

\subsection{A coleta de dados}

As admissões hospitalares de mulheres que necessitam da cirurgia por câncer de mama na enfermaria onde os dados deste estudo foram coletados, ocorrem às segundas e quartas feiras, o que exigia minha presença ali, nesses mesmos dias.

Permanecia sempre próxima ao posto de enfermagem da ala B da enfermaria em questão, assim, no momento em que a escolta chegava com as mulheres que seriam admitidas, eu observava cada prontuário com o objetivo de verificar se a cirurgia proposta era por câncer de mama.

Ao verificar se alguma das mulheres que seriam admitidas tinha como proposta cirúrgica a mastectomia, me informava sobre quem era a profissional responsável pelas admissões daquele plantão e pedia permissão para acompanhá-la na internação que seria realizada. 
Após a formalização da autorização de cada profissional responsável pelas admissões hospitalares, houve a observação, conforme ANEXO C, de cada um deles desde o momento em que a mulher foi chamada na porta da sala de espera para ser levada ao quarto onde permaneceria hospitalizada, até o momento em que esse mesmo profissional deixou o quarto.

Assim que o profissional deixava o quarto, a mulher era convidada a participar da pesquisa. Após seu aceite verbal, formalizado pela assinatura no termo de consentimento pós-informação (ANEXO D), o instrumento de observação era então preenchido (ANEXO E).

As observações realizadas foram do tipo participante. Minayo (1999) coloca que a observação participante pode ser considerada parte essencial do trabalho de campo dentro da abordagem qualitativa de pesquisa porque o observador estabelece uma relação face a face com os entrevistados, e, assim, pode acessar o universo deles, o que, por conseguinte faz com que tanto o observador quanto o contexto sejam modificados.

Segundo Spink (1993, a), a observação é uma etapa fundamental no estudo das representações sociais, possibilitando entender até mesmo a estrutura destas últimas.

Haguette (1995) situa a observação participante como não possuindo ainda uma definição clara no campo das ciências sociais porque cada autor acrescenta um conteúdo novo ao que vem a ser esse método e técnica de coleta de dados.

Nogueira (1977) distingue a observação participante da observação comum ao colocar que a primeira se distingue da segunda por ser uma observação controlada.

Para Chizzotti (1991), a observação pode ser participante quando o investigador "vive" e compreende a dinâmica dos atos e eventos, e recolhe as informações a partir da compreensão e sentido que os atores atribuem aos seus atos.

Gil (1999) afirma que uma das vantagens da observação participante é o esclarecimento de comportamentos dos entrevistados. E Nogueira (1977), relata que através da participação é possível acostumar o "grupo" ao observador, que passa a ser aceito pelos participantes da pesquisa. 
O olhar desta primeira fase esteve voltado a todo o processo que caracteriza a admissão hospitalar de uma mulher a ser submetida à cirurgia por câncer de mama. Essas observações foram acompanhadas pelo registro dos dados coletados no diário de campo (ANEXO F). Esses dados compreenderam: o espaço físico onde ocorreu a admissão hospitalar; os profissionais envolvidos, com os eventos e situações do momento; os objetos que compunham o ambiente observado, com que finalidades eram utilizados; o período de cada observação e o objetivo de cada profissional envolvido. Além disso, as observações tiveram como finalidade registrar como cada mulher se comportava, o que sentia e como deu significado a esse momento.

Triviños (1987) considera as anotações de campo como uma etapa fundamental na coleta dos dados porque estes últimos podem ser utilizados: para análises finais; como ponto de referência para guiar o pesquisador se o procedimento adotado é válido; para reavivar a consciência do pesquisador em relação a aspectos despercebidos; na formulação de novas idéias; no descobrimento de omissões nas descrições, e, possibilitar uma reavaliação até mesmo dos pressupostos da pesquisa.

Num segundo momento foram colhidas entrevistas abertas semi-estruturadas, com as mulheres admitidas. Segundo Spink (1993, a), o que é central nas representações sociais é a conversação, e é por meio da utilização de entrevistas que o pesquisador tem a possibilidade de acessar o universo simbólico do entrevistado e conseqüentemente acessar as representações sociais.

Haguette (1995), define a entrevista como um processo de interação entre pessoas, cujo objetivo é a obtenção de informações do entrevistado.

A mesma autora ainda afirma que a busca pela objetividade é sempre algo a ser buscado, já que a entrevista é um instrumento de coleta de dados como qualquer outro, mas sempre o pesquisador deve estar atento para o fato de que a objetividade plena é algo inatingível, entretanto nunca deve ser escravo dessa premissa, porque ao se submeter a esse inatingível, não tentará alcançar o máximo de objetividade possível. Além disso, a importância de que o que se capta enquanto dado é sinônimo de leitura do real.

Polit \& Hungler (1995) definem a entrevista como um método de auto-relato que tende a ser como conversas permitindo aos sujeitos narrarem suas histórias. 
Minayo (1999), que assim como Haguette é uma das representantes da linha sociológica, aponta a entrevista como fazendo parte da relação mais formal ao se estar realizando o trabalho de campo, relação essa que implica uma intencionalidade, que seria a obtenção de informações por meio da falas dos entrevistados, chamados por ela de atores sociais. Essa obtenção de informações pode ser obtida por meio de dados secundários e primários. Os primeiros seriam aqueles obtidos principalmente por meio de documentos. Já os dados primários são aqueles pertencentes ao mundo simbólico do entrevistado. Mas, a maior contribuição dessa autora é a concepção de que a entrevista, por meio da palavra é capaz de comunicar representações de grupos específicos em condições históricas, culturais e sócio-econômicas específicas.

Bogdan \& Biklen (1999) afirmam que no âmbito da investigação qualitativa a entrevista pode ser a estratégia principal de coleta de dados, ou ela pode estar aliada a outras técnicas como, por exemplo, a da observação participante. Entretanto, ressaltam que os dados têm de descrever a linguagem do próprio participante da pesquisa, e então, ao investigador é permitido desenvolver de forma intuitiva o modo como os sujeito interpretam fragmentos da realidade que os rodeiam.

Gil (1999) reconhece que para a entrevista acontecer há a necessidade de um investigador e um investigado, sendo que o primeiro utiliza-se de perguntas para a obtenção de dados que são relevantes à investigação. Portanto é um diálogo que ocorre de forma que ambos ocupam posições distintas, já que ao entrevistador busca os dados e o entrevistado coloca-se como fonte desses dados.

Romanelli menciona que a entrevista é uma relação entre duas pessoas,

"que cria uma forma de sociabilidade específica, limitada no tempo, sem continuidade, em que, inicialmente, os parceiros da díade se defrontam como estranhos, pautados por uma alteridade que aparentemente não admite o encontro e que deve ser superada para que a matéria-prima do conhecimento possa ser produzida durante esse encontro que forma estranhos em parceiros de uma troca” (Romanelli, 1998, pg. 125 e 126).

Polit \& Hungler (1995) definem que a entrevista, como um dos instrumentos de relato verbal, possibilita o acesso direto ao que as pessoas pensam, sentem ou 
acreditam. Além disso, a entrevista é um instrumento capaz de captar dados de atividades e comportamentos passados, bem como de comportamentos futuros.

As entrevistas de nosso estudo foram realizadas em um local reservado da enfermaria, onde não havia trânsito de pessoas e nem barulho, onde permaneceram entrevistadora e entrevistada porque o interesse foi preservar a integridade psicológica de cada mulher que participou do estudo, além do que, esse encontro face a face também proporcionou uma profundidade maior dos dados coletados, o que vai também ao encontro de uma das características do estudo qualitativo, que é mesmo trabalhar com menos sujeitos, mas com dados pautados pela profundidade.

Questões norteadoras da entrevista:

1.0 que te traz aqui?

2 Conte-me o que aconteceu para você estar aqui hoje.

3.Como é estar chegando aqui para realizar essa cirurgia?

4. Como você se sente chegando aqui?

5. Como você descreve esse lugar?

6. O que você pensa ou faz em situações diferentes de outras que você já passou?

$7 \mathrm{O}$ que te vem à cabeça neste momento?

\subsection{Período de coleta}

As entrevistas foram realizadas no período de Outubro a Dezembro de 2002 e tiveram duração média de trinta minutos. Ao término de cada uma delas eu agradecia e acompanhava cada uma das entrevistadas até o quarto de onde havíamos saído juntas para a entrevista. 


\subsection{Aspectos éticos}

O presente estudo contou com a aprovação favorável do Comitê de Ética em Pesquisa do hospital-escola onde os dados deste estudo foram coletados, conforme parecer (ANEXO A). Após essa autorização foi dado início à versão definitiva deste estudo.

Por entendermos que seria importante resguardar eticamente, além das participantes desta pesquisa, cada profissional responsável pela admissão hospitalar das mulheres com câncer de mama, elaboramos um termo de consentimento pósinformação para os principais profissionais da saúde envolvidos no procedimento da admissão hospitalar, bem como para as mulheres que foram sujeito deste estudo (ANEXOS B e D).

O gravador foi ligado em todas as entrevistas somente após a certeza de que cada entrevistada havia compreendido cada item presente no termo de consentimento pós-informação (ANEXO D).

A nona participante era analfabeta, o que a impossibilitava em assinar o termo de consentimento pós-informação, por isso, foi lido várias vezes o termo até o entendimento da participante, sendo a formalização de seu aceite gravada antes do início da entrevista.

\subsection{Análise dos dados}

Todas as entrevistas foram transcritas segundo as normas de transcrição dispostas no ANEXO G (Preti, 1999). Essas entrevistas passaram por uma leitura flutuante para que os temas mais relevantes em relação à admissão hospitalar para a realização da cirurgia por câncer de mama pudessem emergir (Spink, 2000).

A indicação de cada entrevistada foi realizada através de nomes fictícios para que a leitura dos dados referentes a cada uma delas pudesse ficar facilitada. 
As dimensões mais relevantes definidas através da leitura flutuante das dez entrevistas realizadas foram: 1) chegada ao hospital; 2) separação; 3) cirurgia; 4) participação na decisão e/ou desconhecimento da cirurgia; e, 5) enfrentamento.

Todas essas dimensões foram organizadas em mapas de associações de idéias, nos quais cada fala foi colocada na ordem em que foi verbalizada durante a realização de cada entrevista. Essa organização possibilita a visualização da associação de idéias das participantes em relação a cada dimensão previamente definida (Spink, 2000).

Para cada mapa associativo foi construído um gráfico, em que os dados foram reunidos de forma que os pensamentos, os afetos e as práticas de cada participante da pesquisa tivessem relação entre si (Spink, 2000).

Os gráficos foram capazes de tornar mais concreto também a visualização das representações sociais que as mulheres entrevistadas relataram em relação à admissão hospitalar para a realização da cirurgia por câncer de mama.

Os gráficos e mapas associativos foram analisados de forma conjunta para cada entrevista realizada. Nessa análise houve a descrição e a busca dos significados das associações correspondentes a cada dimensão encontrada.

Finalizada a análise conjunta dos gráficos e mapas associativos passamos então à análise das representações sociais presentes nos discursos das entrevistadas.

As falas que mais se repetiram foram agrupadas e categorizadas de acordo com a similaridade que apresentaram entre si, de forma que cada categoria pudesse dar sentido às representações sociais que o grupo de mulheres participantes da pesquisa foi porta-voz.

Como optamos por realizar um estudo qualitativo, definimos que os sujeitos de nossa pesquisa teriam que ter todas as suas representações sociais analisadas mesmo que essas últimas não tivessem como ser agrupadas pelo critério da similaridade, porque entendemos que essa forma de análise não permite que todas as participantes do estudo fiquem com seus discursos aprisionados nas categorias definidas, o que nos instrumentaliza ainda para uma compreensão mais ampla das representações sociais das mulheres que fizeram parte de nossa amostra.

As categorias capazes de dar sentido às representações sociais das mulheres que participaram deste estudo foram analisadas enfocando-as como produto, ou 
resultado de pensamentos constituídos e/ou campos estruturados, bem como às condições em que foram produzidas (Spink, 1995).

Além de objetivarmos a compreensão das representações sociais presentes nos discursos das dez participantes desta pesquisa, também buscamos a descrição das estratégias de enfrentamento que cada uma das dez mulheres estudadas se utilizaram para enfrentar a admissão hospitalar necessária para a realização da cirurgia por câncer de mama.

A descrição das estratégias de enfrentamento utilizadas pelas participantes deste estudo foi feita entendendo o enfrentamento enquanto um processo (Gimenez, 1997), o que significa entendê-lo como algo mutável de acordo com o tempo e com possíveis mudanças onde o fenômeno estudado ocorre.

Por entendermos o enfrentamento como algo diretamente relacionado ao tempo e ao contexto em que é estudado fizemos a escolha de descrever as formas de enfrentamento, que as dez mulheres admitidas para se submeterem à cirurgia por câncer de mama utilizaram, de forma vinculada ao modo como foram recebidas pelos principais profissionais envolvidos na admissão hospitalar delas, de acordo com o instrumento de observação presente no ANEXO C e, em acordo com o que a literatura aponta sobre o que é o hospital e o que ele pode despertar nas pessoas que necessitam dele para serem cuidadas. 


\section{RESULTADOS}

A apresentação dos resultados da presente pesquisa será realizada respeitando a seguinte estrutura: cada participante terá os dados de sua entrevista e nossa observação, seguidos pelos respectivos mapas, que contêm as associações de idéias sobre a admissão hospitalar necessária para a realização da cirurgia por câncer de mama e gráficos, os quais foram construídos para cada uma delas, de acordo com Spink (2000).

\section{Participante 1}

Linda é uma mulher de setenta e um anos, procedente de São Simão, SP, semi-analfabeta, casada e trabalha em casa. Ficou grávida nove vezes, passou por sete partos e dois abortos. A cirurgia proposta para Linda foi a de uma mastectomia à esquerda, sendo que em janeiro de dois mil e um foi submetida a uma tumorectomia mais esvaziamento axilar, o que evidencia que essa participante apresenta uma recidiva local.

Linda chegou sozinha à enfermaria,. ao ser indagada sobre o motivo de estar só, respondeu que suas cunhadas tiveram que ficar com os filhos delas e, por isso, não puderam acompanhá-la.

Após a enfermeira sair do quarto, apresentei-me à Linda e expliquei-lhe o motivo de minha presença ali. Após seu aceite, por meio do termo de consentimento 
pós-informação (ANEXO D), e nossa presença num local reservado da enfermaria é que então dei início à entrevista.

Linda chorou bastante durante toda a entrevista e citou várias vezes Deus. Falava de forma um pouco ininteligível pelo fato de pronunciar palavras com muitos erros gramaticais. 


\section{MAPA 1}

Linda

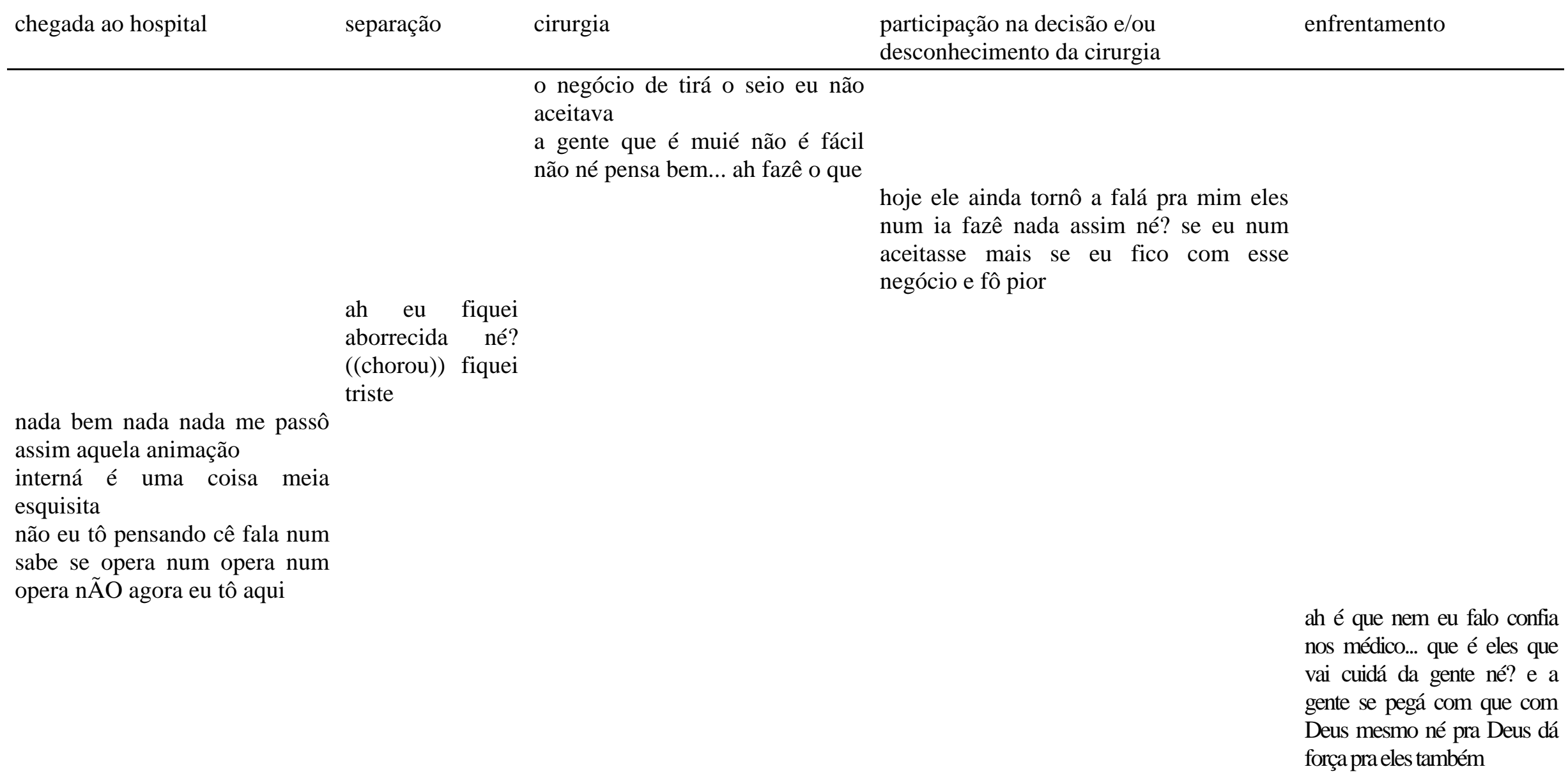


GRÁFICO 1

Linda

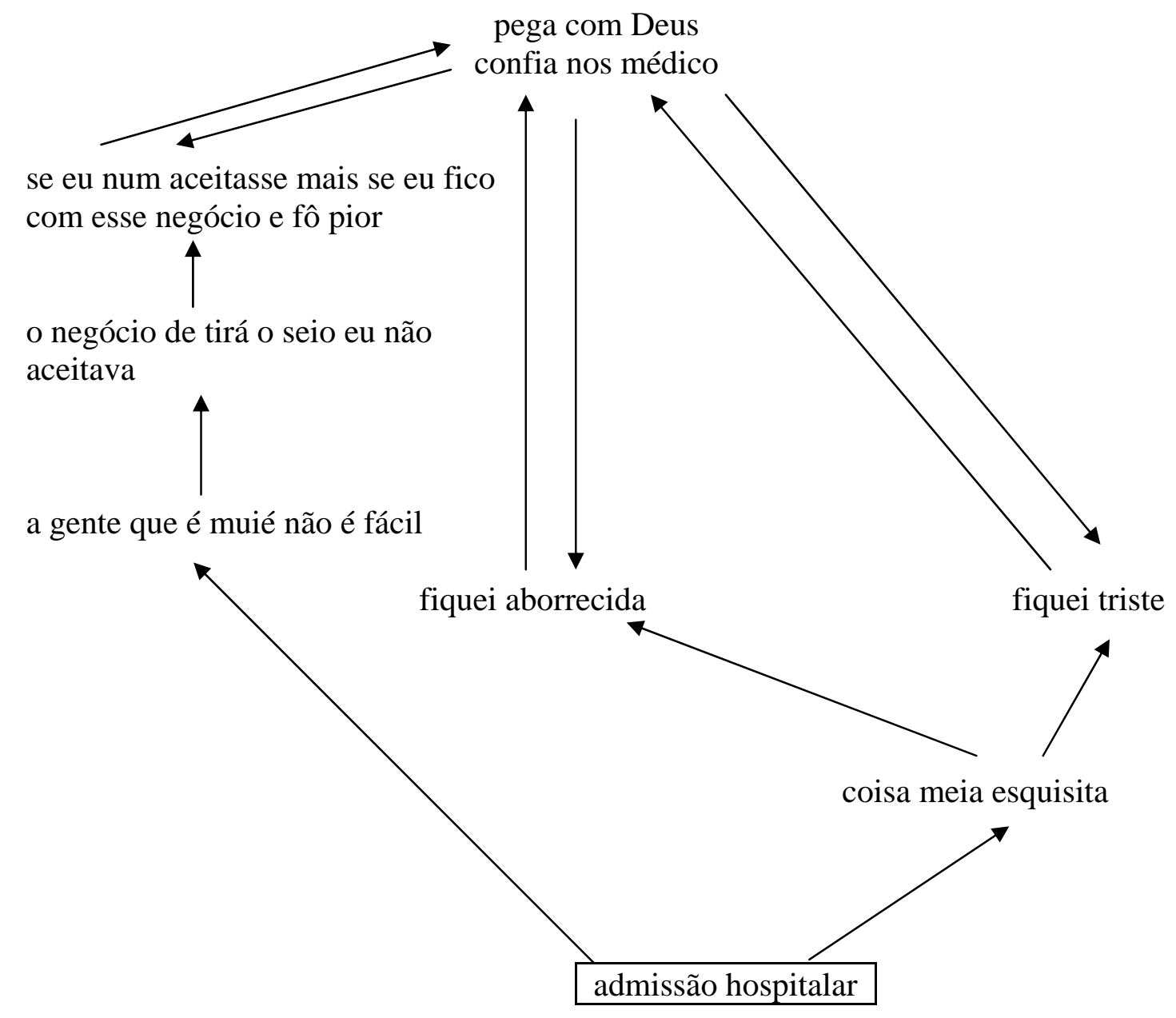




\section{Participante 2}

Áurea tem cinqüenta e nove anos, é procedente de Ribeirão Preto, SP, semianalfabeta, casada e trabalha como faxineira. Não engravidou nenhuma vez em toda sua vida, e teve como proposta cirúrgica uma quadrantectomia com esvaziamento axilar.

Áurea chegou acompanhada por uma cunhada à enfermaria, ao ser chamada pela enfermeira para ser levada ao quarto, demonstrou apenas uma resposta ao estímulo do chamamento e permaneceu em silêncio até a chegada ao quarto.

Depois da saída da acompanhante do quarto, convidei Áurea para participar da pesquisa. Somente após seu aceite, fomos a um lugar reservado na enfermaria e depois da leitura do termo de consentimento pós-informação (ANEXO D) e assinatura do mesmo, dei início à entrevista.

No decorrer da entrevista Áurea mostrou-se bem informada quanto à necessidade do auto-exame das mamas, por meio dele que ela descobriu que tinha algo de anormal no seu seio e procurou ajuda. Foi muito presente ainda a história de uma amiga que teve câncer de mama e está com metástase no fígado e na coluna.

Áurea também relatou sobre uma cirurgia que tinha que fazer para retirada das trompas e raspagem do útero, entretanto, essa cirurgia não ocorreu porque, segundo ela, a anestesia quase lhe levou a óbito. 


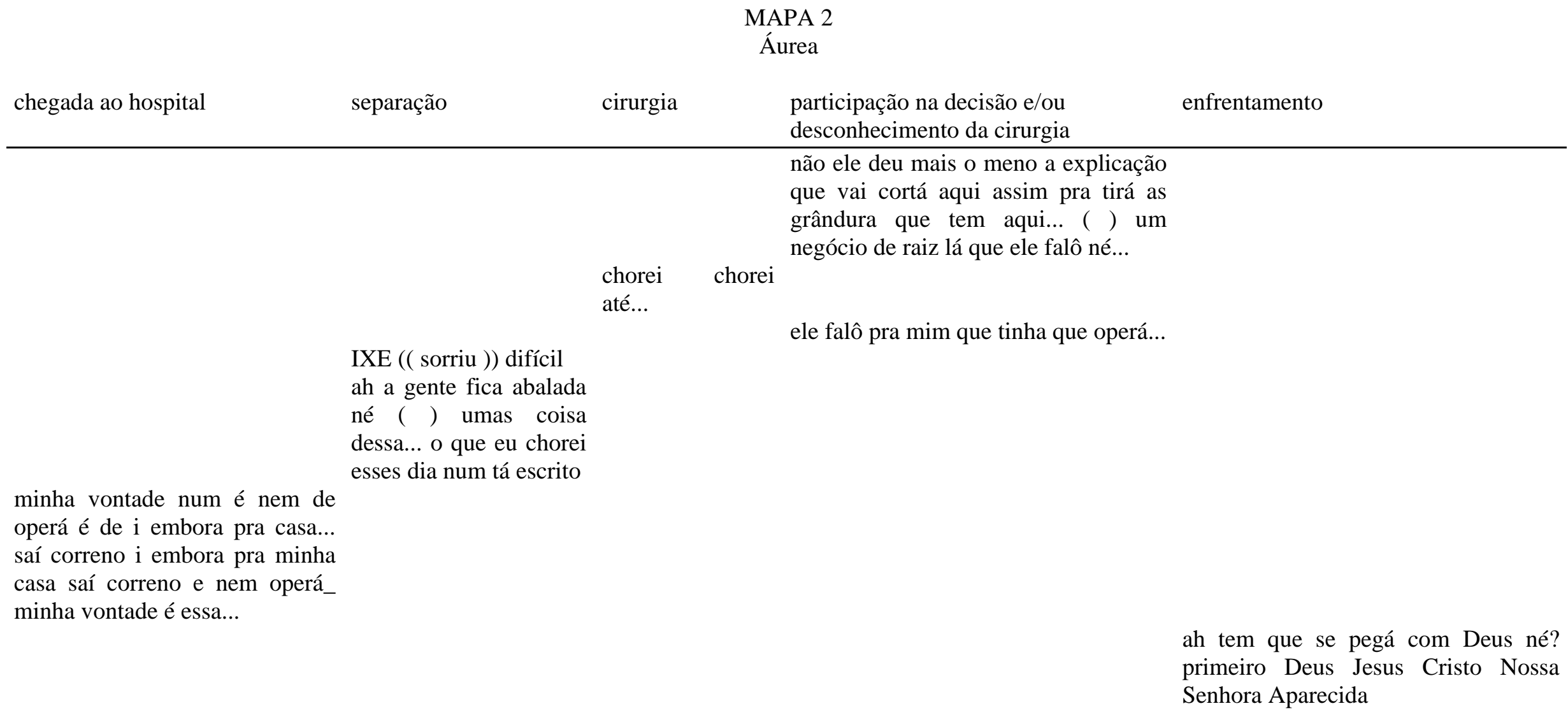




\section{GRÁFICO 2 \\ Áurea}

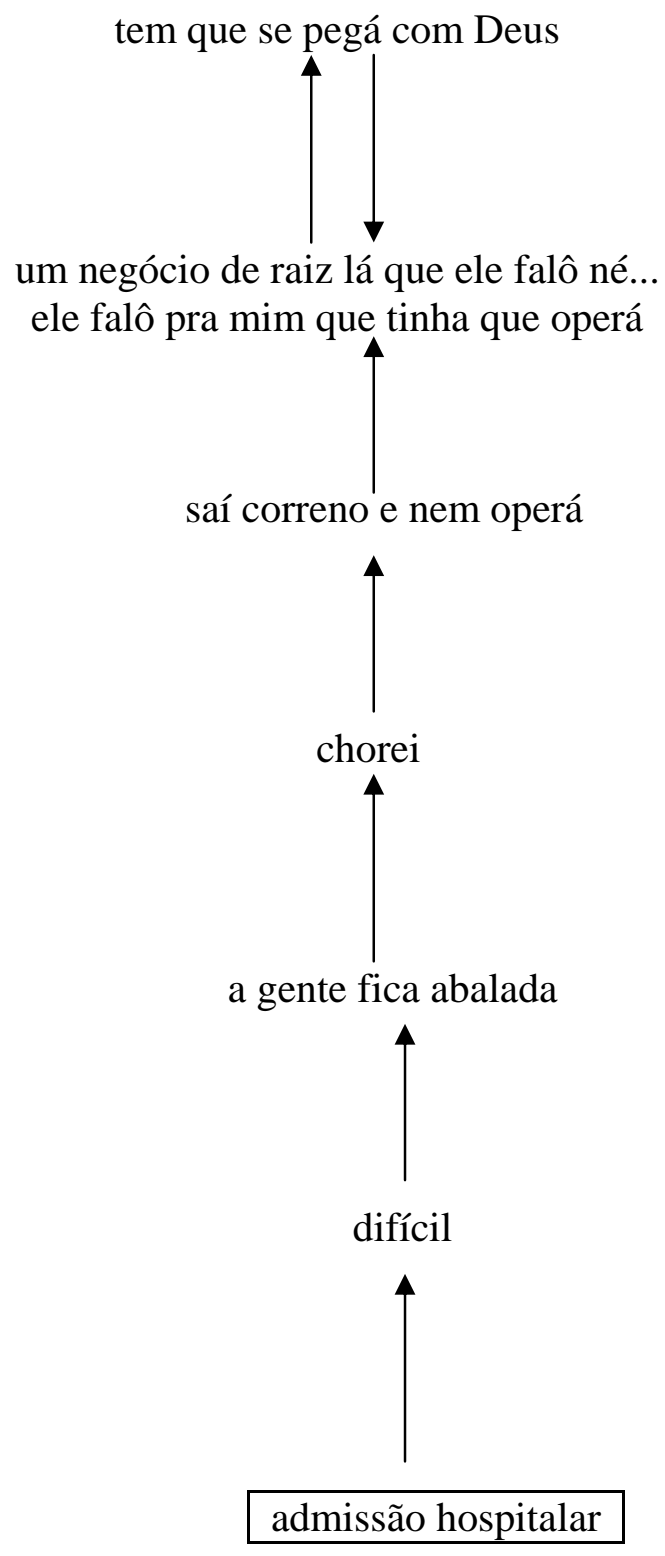




\section{Participante 3}

Laura é uma mulher de quarenta e quatro anos, procedente de Ribeirão Preto, SP, concluiu o ensino fundamental, é divorciada e trabalha em sua própria casa. Passou por duas gestações, dois partos e nenhum aborto. A cirurgia proposta à Laura foi de esvaziamento axilar.

Laura entrou na enfermaria de ginecologia e obstetrícia acompanhada pela sua mãe e durante o trajeto até o quarto questionou a enfermeira se seu cabelo cairia.

Durante a admissão hospitalar, Laura buscou a resolução da dúvida que tinha sobre a capacidade da biópsia ter solucionado o problema do seu câncer.

Ao término da realização dos procedimentos cabíveis da admissão hospitalar, mãe e filha despediram-se na porta do quarto. Laura estava contida, tentava esconder o que sentia e/ou pensava.

Convidei Laura para participar do estudo, informei sobre o significado da pesquisa e, apenas após seu aceite verbal e via termo de consentimento pósinformação (ANEXO D), iniciei a entrevista.

O momento da entrevista foi marcado por uma preocupação acentuada por parte de Laura quanto a uma possível perda do cabelo, que implicaria na visualização de uma deficiência que tem em uma de suas orelhas, uma delas é bem menor do que a outra. Ela relatou que estava mais preocupada com isso do que com a própria cirurgia. 
MAPA 3

Laura

\begin{tabular}{l} 
chegada ao hospital \\
\hline eu num tô assim cum medo \\
trauma com nada num tô com \\
aquele medo nada tô vino \\
assim pra tirá um::: tipo um \\
peso de mim uma doença né? \\
eu tô sentindo uma paiz \\
assim ( ) \\
eu tô sentindo bem penso em \\
acabá logo isso
\end{tabular}

separação cirurgia

participação na decisão e/ou

desconhecimento da cirurgia

enfrentamento

o seio meu eu já fiz o sucesso
com eles né? então como diz
o outro agora é doença né?
é só um pedacinho vai ficá um
pedaço pra usá um
soutienzinho umo

dá uma tristeza não eles falô que vai tirá esse carocinho né que::: vai usá uma mangueira pra drená porque senão esse carocinho aqui custuma inraizá...

não ele falô que ia fazê a cirurgia aí lógico que quem num qué fazê né se tem né? eu tenho que conversá muito e andá (( sorriu )) distrai um pouco

a gente mesma que tem que se pô a confiança 


\section{GRÁFICO 3}

Laura

a gente mesma que tem que se pô a confiança

eu tenho que conversá muito e andá
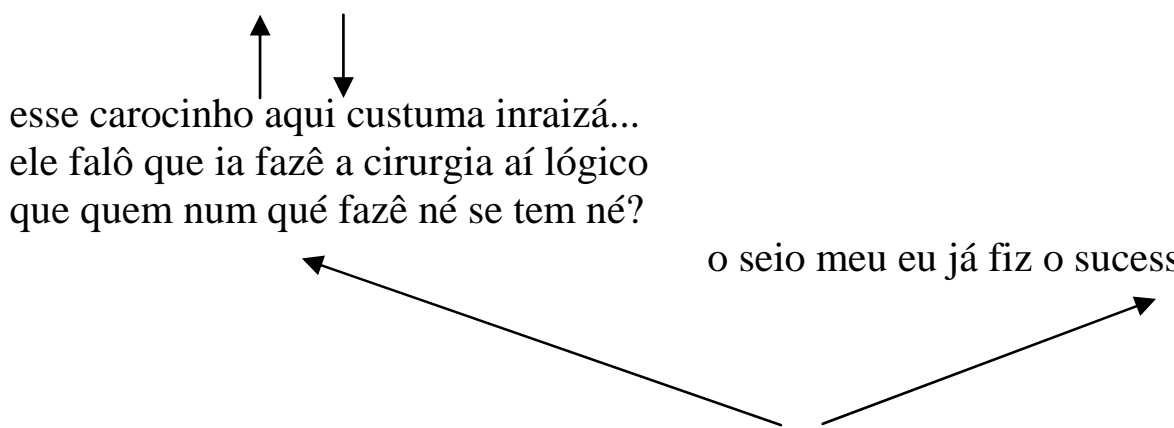

eu tô sentindo bem penso em acabá logo isso
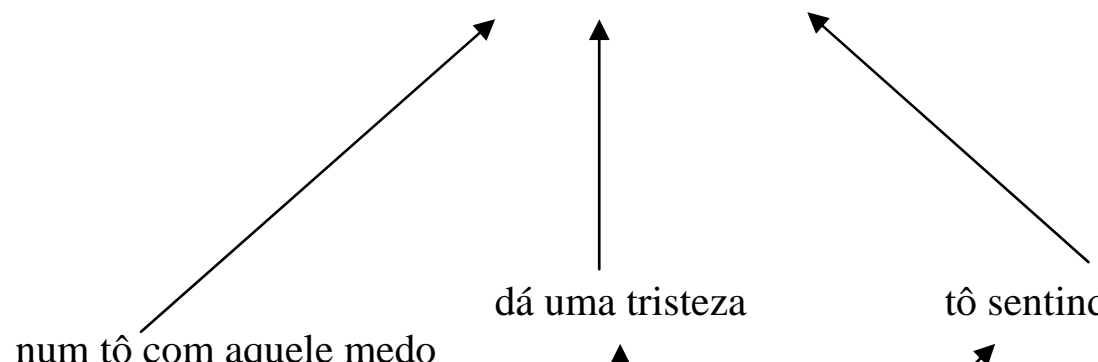

dá uma tristeza

tô sentindo paiz
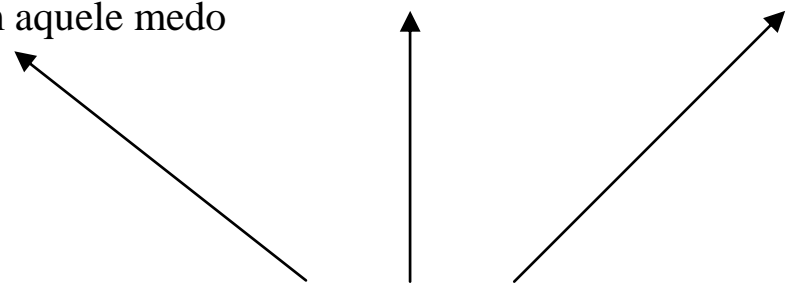

tô vino pra tirá um peso de mim uma doença

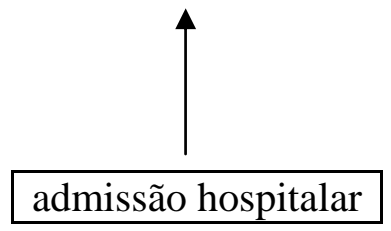




\section{Participante 4}

Marta tem cinqüenta e oito anos, é procedente de Ribeirão Preto, SP, concluiu o ensino fundamental, é viúva e trabalha como costureira. Passou por duas gestações e dois partos e teve como proposta cirúrgica uma quadrantectomia mais esvaziamento axilar.

Marta chegou à enfermaria acompanhada pela filha, que foi embora logo que a mãe foi chamada. Elas despediram-se na porta da sala de espera, com Marta tentando conter seus sentimentos.

No caminho para o quarto, Marta iniciou o diálogo com a enfermeira responsável por sua internação demonstrando preocupação porque não queria ficar sem seu relógio.

Mais tarde, durante a entrevista, ela relatou que sua filha organizou e conversou com os médicos sobre a realização da cirurgia, e também comunicou a toda a família que Marta estava com câncer. 
MAPA 4

Marta

$\begin{array}{ll}\text { chegada ao hospital } \quad \text { separação } \quad \text { cirurgia } & \begin{array}{l}\text { participação na decisão e/ou } \\ \text { desconhecimento da cirurgia }\end{array}\end{array}$

eu acho que é::: um meio deu::: deu solucioná meu problema...

ah não muito bom senti bem

\begin{abstract}
eu acho que já deve fazê tudo de uma veiz só então faiz esse esvaziamento porque de repente você tira lá uma microcalcificação que não tem nada... e não faiz o serviço completo daqui dois ou treis anos pode surgir outro tipo de problema né...
\end{abstract}

não cê sabe que nem foi direto comigo

((foi com a filha))

e eu concordei.. aqui...

normal... ontem

à tarde parece

que eu tava

meio assim

eu me senti

muito segura

mais eu tava

muito

emocionada

ontem... 
eu tive vontade

de chorá... ( )

eu num vô falá pra você que eu sô RE-LI-GI-O-SA eu tenho minhas crenças... eu num me apego eu faço minhas orações e sei que vô vencê

minha família assim eu tenho uma irmã que a gente se dá muito e tenho esse namorado

tô muito otimista..

isso pra mim não é nada eu vô superá TUDO... eu tô assim... tô muito feliz... não é esse problema que que eu tenho agora vai me abatê não... vô superá tudo 
GRÁFICO 4

Marta

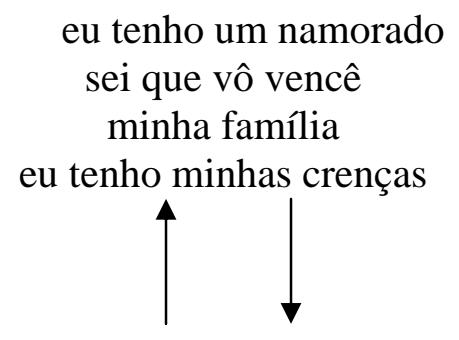

eu acho que já deve fazê tudo de uma veiz só nem foi direto comigo ((foi com a filha))

e eu concordei

tô muito otimista... isso pra mim não é nada eu vô superá TUDO

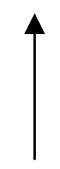

eu me senti muito segura mais eu tava muito emocionada

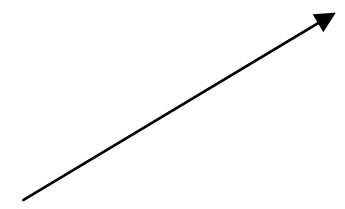

um meio deu solucioná meu problema

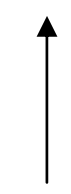




\section{Participante 5}

Isolina tem quarenta e cinco anos e é procedente de Jardinópolis, SP. Completou o ensino fundamental, é separada e trabalha em casa. Passou por seis gestações, cinco partos e um aborto. A cirurgia proposta à Isolina. foi de uma tumorectomia com esvaziamento axilar.

Isolina chegou sozinha à enfermaria, no trajeto até o quarto e durante sua permanência com a enfermeira, se limitou a responder o que lhe foi perguntado.

Somente após a aceitação livre e via termo de consentimento pós-informação (ANEXO D) de Isolina, iniciei a realização da entrevista.

Durante a realização da entrevista Isolina relatou ter trauma e medo de cirurgia, mas, a concebia também como um procedimento muito importante para o tratamento de seu câncer de mama. 
MAPA 5

Isolina

\begin{tabular}{|c|c|}
\hline chegada ao hospital & cirurgia \\
\hline $\begin{array}{l}\text { tem que vir porque né... } \\
\text { cuidá da minha saúde }\end{array}$ & \\
\hline & $\begin{array}{l}\text { tenho um pouco de medo eu } \\
\text { tenho medo medo de cirurgia } \\
\text { sabe assim um trauma sei lá } \\
\text { assim de cirurgia }\end{array}$ \\
\hline
\end{tabular}

participação na decisão e/ou

enfrentamento

desconhecimento da cirurgia

tô calma

ah a gente fica

assim eu nunca

dexei

eu tenho muita força de vontade assim e::: e me incoraja muito a vir

tenho... confiança que vai... ficá saí tudo bem

me deu aquela coragem assim de de infrentá e vim sozinha

ah fé em Deus que tudo ia sê

é uma complementação do resolvido...

meu tratamento

me deu aquele pavor

chorei bastante

cê tem que fazê agora cê que resolve

todo mundo começô dá força apoiá falá não cê vai vencê aí eu criei corage

fui bem recebida bem

tratada 
pensei que eu vinha...

internava né vô fazê a

cirurgia... e vô saí bem

penso em várias pessoa que já feiz essa cirurgia e passô por esse mesmo momento que eu passei e muita fé em

tô tranqüila... de verdade... 


\section{GRÁFICO 5}

Isolina

eu tenho muita força de vontade e::: $\longleftrightarrow \quad$ e me incoraja muito a vir

tenho... confiança que vai... ficá saí tudo bem

me deu aquela coragem assim de infrentá e

vim sozinha

fé em Deus que tudo ia sê resolvido...

todo mundo começô dá força apóia falá não cê vai vencê

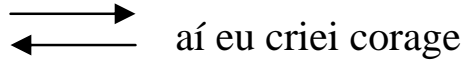

penso em várias pessoa que já feiz essa

cirurgia e passô por esse mesmo momento

que eu passei e muita fé em Deus

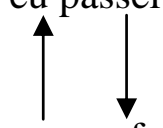

cê tem que fazê agora cê que resolve

me deu aquele pavor

chorei bastante

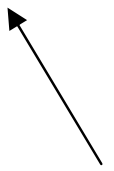

tô tranqüila...

pensei que eu vinha... internava

né vô fazê a cirurgia... e vô saí

bem

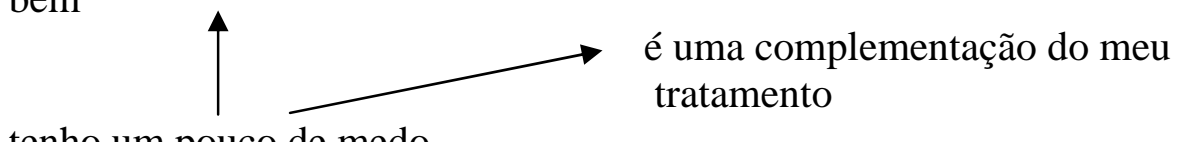
de verdade...

tenho um pouco de medo

eu tenho medo medo de cirurgia

sabe assim um trauma

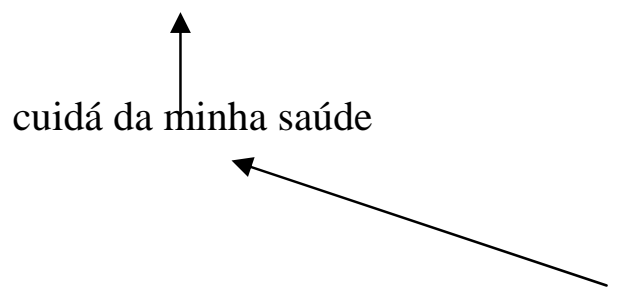

fui bem recebida bem tratada

admissão hospitalar 


\section{Participante 6}

Tarcila é uma mulher de quarenta e um anos, procedente de Itamogi, MG, completou o ensino fundamental, é casada, é trabalhadora do lar, além de lavradora de café. Ficou grávida cinco vezes, passou por três partos e dois abortos. A cirurgia proposta à Tarcila foi de uma quadrantectomia com esvaziamento axilar.

Tarcila chegou acompanhada à enfermaria, antes de nos acompanhar até o quarto, despediu-se na porta da sala de espera de sua acompanhante. A despedida foi marcada pela não demonstração do que ela sentia e/ou pensava naquele momento.

No trajeto até o quarto e durante seu contato com a enfermeira que realizou sua admissão hospitalar ela apenas respondeu o que lhe foi perguntado.

A participação de Tarcila nesta pesquisa somente ocorreu após seu consentimento via termo de consentimento pós-informação (ANEXO D).

Tarcila relatou no decorrer da entrevista que estava bastante esperançosa quanto à resolução do seu caso através da realização da cirurgia. Porém, contou que internar, na sua concepção, não era bom. 
MAPA 6

Tarcila

$\begin{array}{ll}\text { chegada ao hospital } \quad \text { separação } \quad \text { cirurgia } & \begin{array}{l}\text { participação na decisão e/ou } \\ \text { desconhecimento da cirurgia }\end{array}\end{array}$

uai pra mim é uma coisa muito boa

tô com a doença vô sê operada ( ) uma coisa que eu espero ficá curada né? aquilo é uma coisa que num pode dexá... sinto assim ótima

((sorriu)) uai na minha opinião num é nada bom né? ((sorriu)) porque se a gente não pudesse entrá::: num ficá internada era uma BOA porque ninguém gostaria de interná e passa ainda mais por uma cirurgia... então pra mim num é nada bão ((sorriu))...

ah não o lugar aqui é ótimo é muito bem tratado... os médico os enfermeiros que cuida da gente são ótimos num tenho nada que cramá é muito bão bão assim a

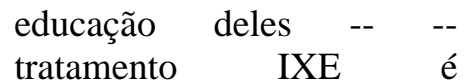
excelente... essa parte óia é 
um prazer sabe? conversá

com eles dá muita atenção...

são muito bão...

primeiro lugar Deus depois alumia os médico... então meu pensamento é só oração é só pensá em Deus... 


\section{GRÁFICO 6}

Tarcila

primeiro lugar Deus depois alumia os médico... então meu pensamento é só oração é só pensá em Deus...

sinto assim ótima

tô com a doença vô sê operada

( ) uma coisa que eu espero

ficá curada né? aquilo é uma

coisa que num pode dexá...

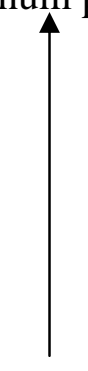

pra mim é uma coisa muito boa

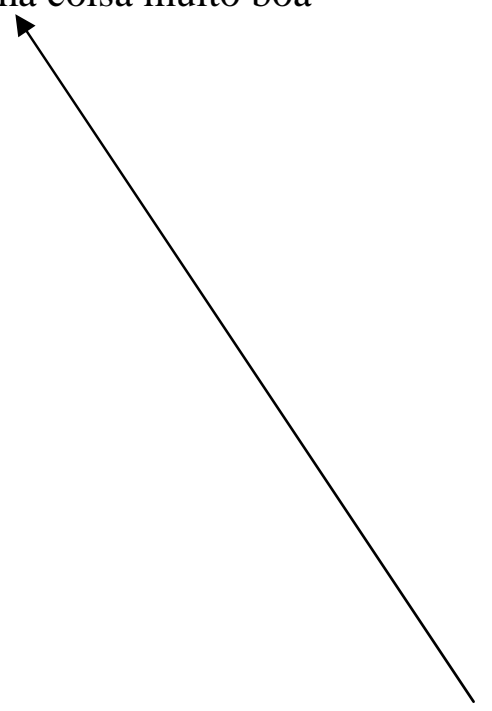

num é nada bom né? ((sorriu))

ele falô que precisava e eu concordei
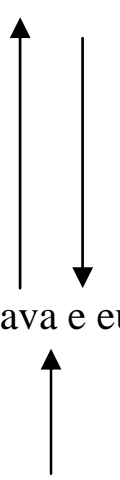

porque ninguém gostaria de interná

e passá ainda mais por uma cirurgia...
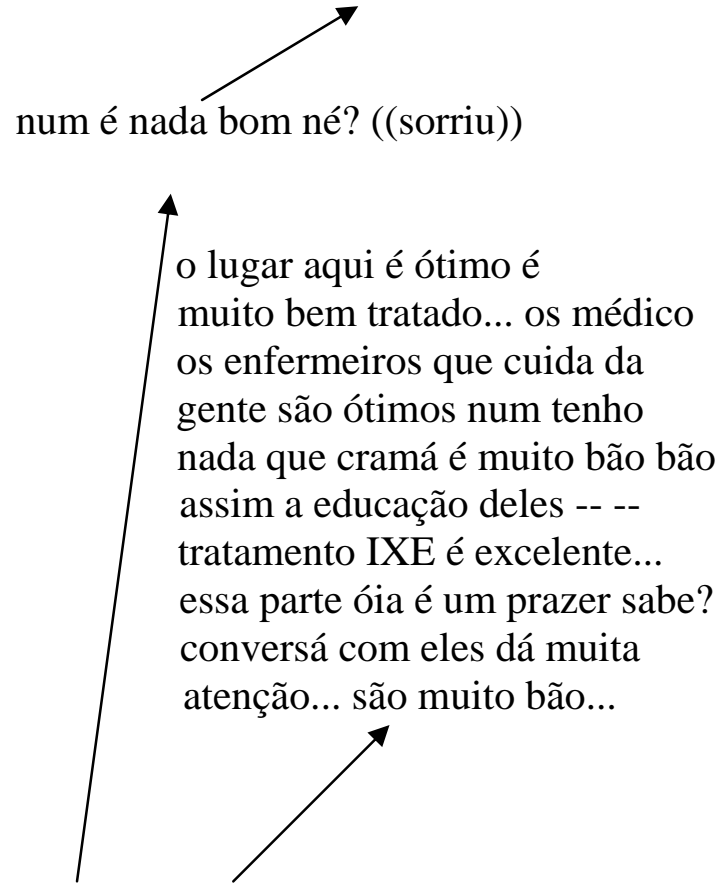

admissão hospitalar 


\section{Participante 7}

Neusa tem cinqüenta anos, é procedente de Pontal, SP e tem o terceiro grau completo, com formação nas áreas de história e geografia, é viúva, trabalha como professora, passou por uma gestação e nenhum aborto. Teve como proposta cirúrgica uma tumorectomia com esvaziamento axilar.

Neusa chegou acompanhada à enfermaria, ao ser chamada, despediu-se de sua acompanhante na porta da sala de espera tentando esconder aquilo que sentia e/ou pensava.

No trajeto até o quarto, onde permaneceria a maior parte do tempo, relatou que gostaria de ir embora em breve por causa de sua filha que é deficiente.

Após a saída da enfermeira do quarto convidei Neusa para participar desta pesquisa, participação que somente ocorreu após seu consentimento formalizado por meio do termo de consentimento pós-informação (ANEXO D).

Na entrevista, Neusa falou muito e se utilizou, várias vezes, das marcas discursivas “né” e "sabe”.

Neusa mostrou-se ainda desinformada em relação ao tempo em que ficaria com o dreno e quanto aos cuidados com o braço do lado operado. Finalizou a entrevista relatando que para a morte não há solução. 
MAPA 7

Neusa

\begin{tabular}{l} 
chegada ao hospital \\
\hline é muito difícil... de falá pra \\
você o que que é a gente \\
vem mesmo porque é \\
obrigado a vir né? \\
num é fácil
\end{tabular}

participação na decisão e/ou desconhecimento da cirurgia enfrentamento

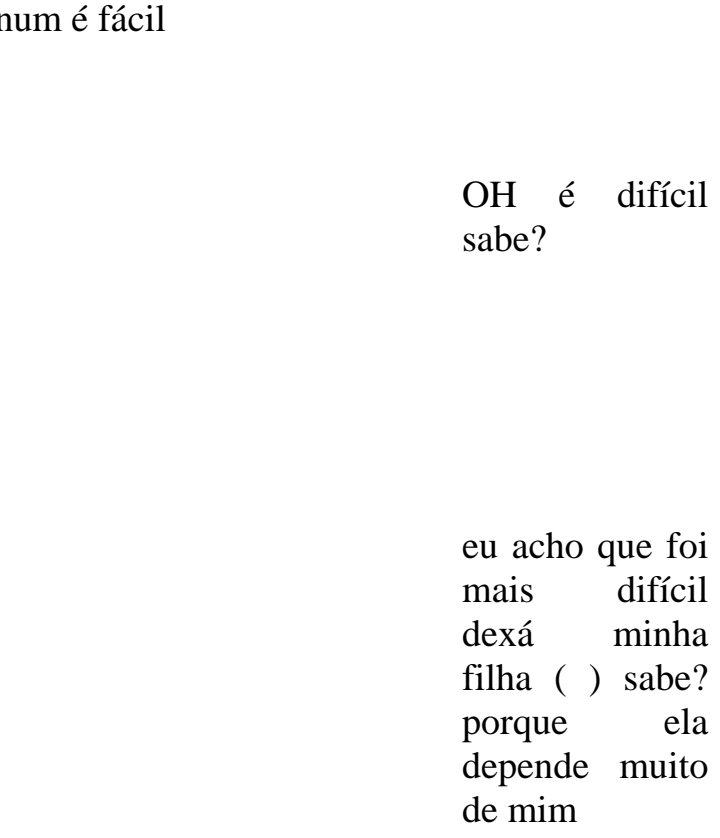

\section{$\mathrm{OH}$ é difícil \\ sabe?}

eu acho que foi

mais difícil

dexá minha

filha ( ) sabe?

porque ela

depende muito

de mim

num é fácil

a única coisa que eu fiquei eu num penso eu... fico assim em casa pensando que eu num tenho nada sabe?...

mais eu procuro não pensá...

não não num perguntô ele falô que seria necessário fazê a cirurgia né? cê analisando bem cê concorda né porque::: se fô também dexá raiz alguma coisa tem que tirá tudo sempre procurei vivê assim no meio de pessoa que brinca que passa energia pra você 
foi com vontade de i embora ((sorriu))

só na hora da cirurgia isso

eu penso

se eu vô tê reação da anestesia

se eu num vô das outras vezes

que eu tomei eu não tive então

cê pensa né como é que pode acontecê ( ) essas coisa assim 


\section{GRÁFICO 7}

Neusa

Deus

sempre procurei vivê assim no meio de pessoa que brinca que passa energia pra você

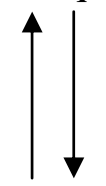

ele falô que seria necessário fazê a cirurgia né?

cê analisando bem cê concorda né porque::: se fô também dexá raiz

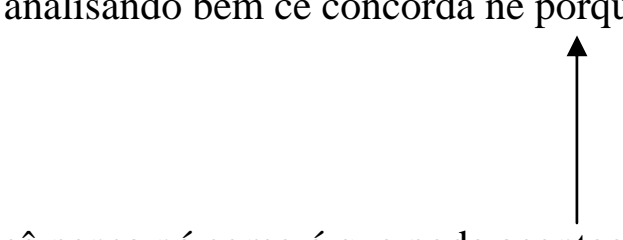

cê pensa né como é que pode acontecê ( ) essas coisa assim ( )

mais eu procuro não pensá

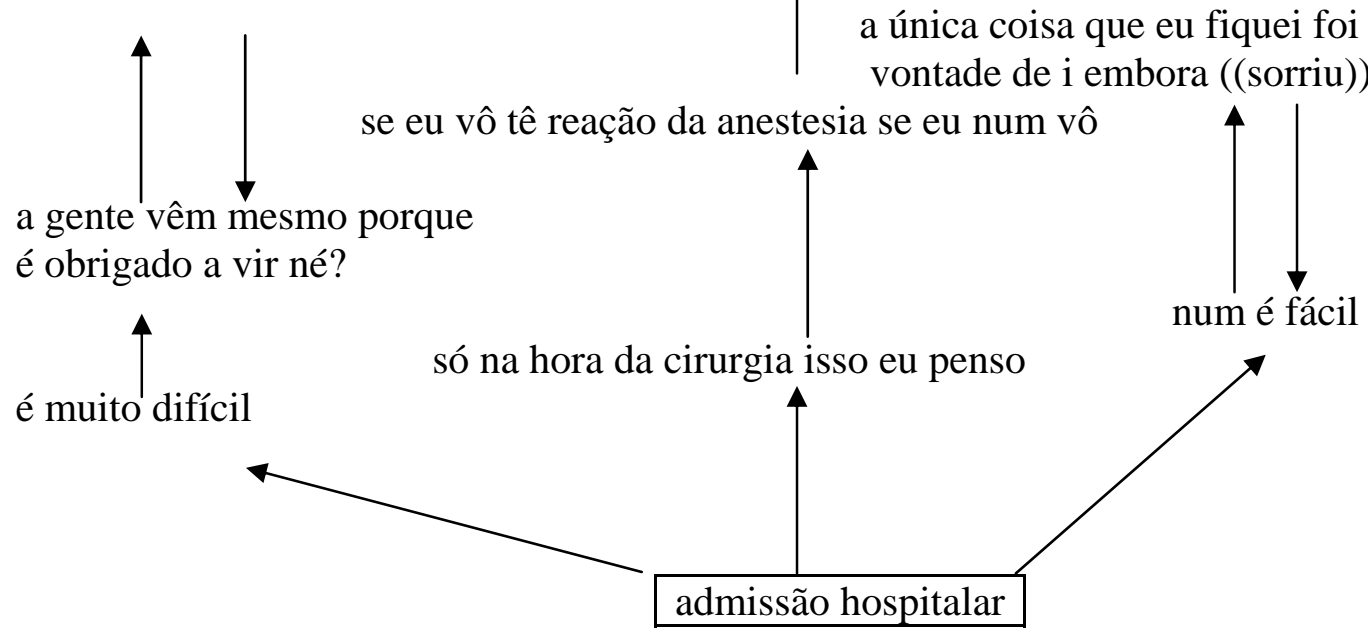

a única coisa que eu fiquei foi com vontade de i embora ((sorriu))

a gente vêm mesmo porque

é obrigado a vir né?

das outras vezes que eu tomei eu não tive

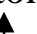




\section{Participante 8}

Sônia é uma mulher de quarenta e quatro anos, é procedente de Ribeirão Preto, SP, não concluiu o ensino fundamental, é casada, trabalha em casa, passou por uma gestação e tem um filho. A proposta cirúrgica para seu caso foi de uma mastectomia à Halsted.

Sônia chegou acompanhada pelo filho à enfermaria, contou no trajeto até o quarto em que ficaria hospitalizada, que havia comparecido hoje numa consulta no ambulatório do hospital, onde já estava sendo assistida e, nessa consulta, foi decidido que era necessário fazer a cirurgia imediatamente.

A mama que seria retirada de Sônia apresentava um tamanho bem superior quando comparado à mama do lado oposto, aliado a isso havia a queixa de uma dor muito intensa nessa mama, dor que era acompanhada pela expulsão de pus.

Após a saída da enfermeira do quarto, Sônia despediu-se de seu filho pedindo que ele não chorasse, mais tarde, fui informada que ele teve de ser consolado por uma das enfermeiras de plantão. Após seu filho ter deixado o quarto, Sônia contoume chorando que sua mãe também já havia sido acometida pelo câncer de mama.

Esperei que Sônia ficasse mais calma para que pudesse convidá-la a participar da pesquisa, e apenas iniciei a entrevista após seu aceite via termo de consentimento (ANEXO D). Devido à sua dor, e pelo fato de haver apenas uma mulher internada no quarto naquele momento, propus a realização da entrevista dentro do quarto, o que foi aceito por ela.

No decorrer da entrevista Sônia relatou ter conhecimento do procedimento que seria realizado. Contou que não aceitava a doença em seu corpo e fazer a quimioterapia era como tomar um copo d’água. 
MAPA 8

Sônia

$\begin{array}{lll}\text { chegada ao hospital } \quad \text { separação } \quad \text { cirurgia } & \begin{array}{l}\text { participação na decisão e/ou } \\ \text { desconhecimento da cirurgia }\end{array} & \text { enfrentamento }\end{array}$

já fico livre né dessa dor

eu num importo se tirá o peito

eu num vô tê proveito

mesmo...

eu... já sei como é como é o

a minha cabeça a cabeça de

qualqué um fica leve...

tenho medo

medo das agulhas medo da

hora deu acordá e vê sangue

o que eu mais tenho medo é

sangue ((emocionou-se))

é ficá aqui tomá os remédio passá pelo tratamento pra depois operá...

a gente se sente como se a

gente tivesse em casa são

muito educado são muito

carinhoso com qualqué pessoa que vêm aqui e só o carinho deles ajuda as

pessoa que tá aqui

internada... eles é muito

vai ficá uma parte defeituosa... ele falô que eu tinha que fazê... 
atencioso...

Deus porque Deus é os médico dos médico além dele é os médico daqui

tô achano uma BOA ((sorriu))

porque quanto mais eu sará e

fazê a cirurgia mais rápido eu

vô sará

da Terra 


\section{GRÁFICO 8}

Sônia

Deus porque Deus é os médico dos médico

além dele é os médico daqui da Terra

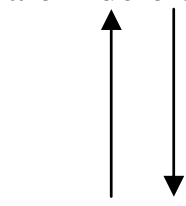

ele falô que eu tinha que fazê

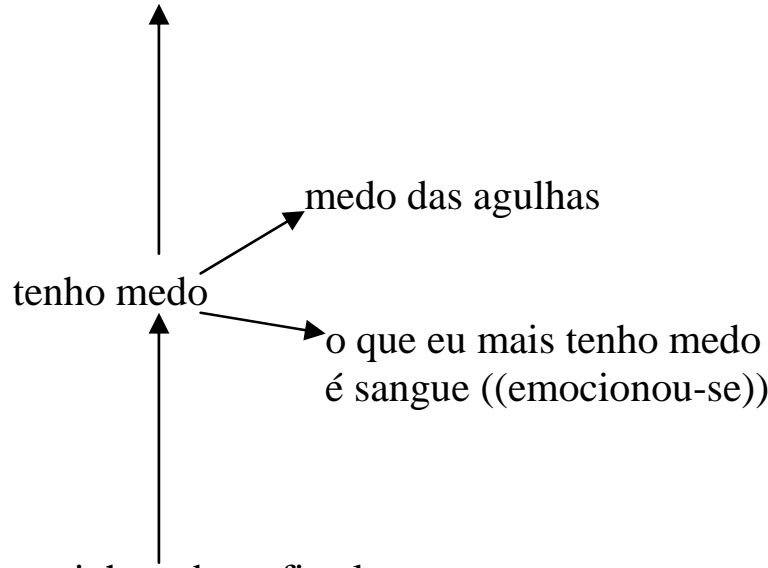

a minha cabeça fica leve

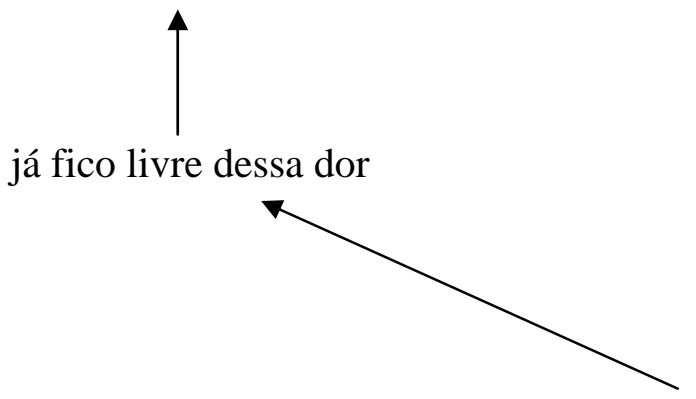

a gente se sente como se a gente tivesse em casa

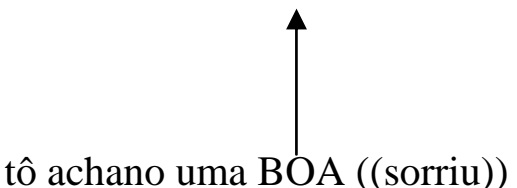
porque quanto mais eu sará e fazê a cirurgia mais rápido eu vô sará

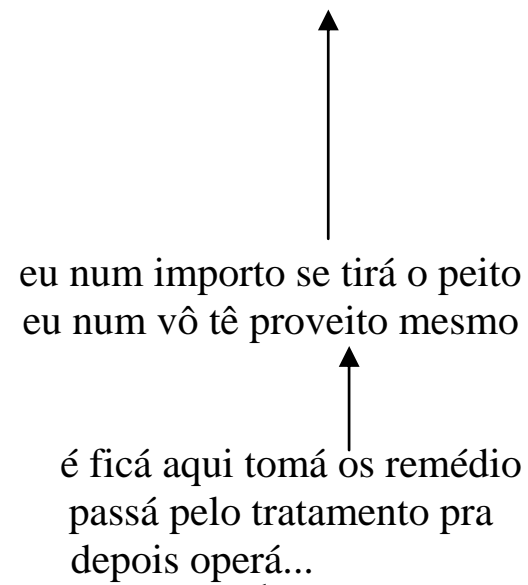

admissão hospitalar 


\section{Participante 9}

Mirtes é uma mulher de setenta e um anos, é procedente de Ribeirão Preto, SP, analfabeta, viúva e trabalha em sua própria casa, ficou grávida duas vezes e passou por dois partos. Teve como proposta cirúrgica uma mastectomia.

Mirtes chegou sozinha à enfermaria, no trajeto até o quarto respondeu à enfermeira que esta era a terceira vez que ela entrava nesta enfermaria.

Após a enfermeira sair do quarto, convidei Mirtes para participar da pesquisa. Essa participação foi oficializada através da gravação de seu aceite, pelo fato de Mirtes ser analfabeta.

Na entrevista, Mirtes demonstrou compreender a internação como uma escolha individual, necessária para o cuidado principalmente de sua doença. Contou também que estava sentida em saber que perderia a mama por entendê-la como algo que Deus lhe deu, assim, não deveria ser privada dela. Além de ter demonstrado pesar por saber que perderia uma mama, Mirtes também estava preocupada por ter deixado um neto que cuida em casa e, estava muito triste com a ausência de seu marido, falecido há três meses. 
MAPA 9

Mirtes

chegada ao hospital separação cirurgia $\begin{aligned} & \text { participação na decisão e/ou } \\ & \text { desconhecimento da cirurgia }\end{aligned} \quad$ enfrentamento

pra gente se cuidá né? cuidá

da doença da gente né...

eu fiquei meia assim

eu fico sentida porque é

metade do meu corpo porque

parece que Deus a natureza

deu pra gente vivê pra sempre

( ) mais tem a doença tem que

tira né fazê o quê

porque:::

tenho um filho

que mora junto

comigo

tem um

menininho

pequeno que eu

tomo conta...

fico sentida

dexá meu filho

em casa

aí eu fiquei

assim falei ai

meu Deus dexá

esse menino

bom...

pequeno aqui.. 
a gente fica pensativa né

num sabe se a gente vai vivê

vai morrê

tem que tê muita fé em Deus

eu vô operá e vô ficá boa

né?

priguntô priguntô aí eu falei que

queria porque é que nem ele falô se

eu num operasse ( $)$ ia passá prus

pulmão aí podia prejudicá mais

ainda 


\section{GRÁFICO 9}

Mirtes

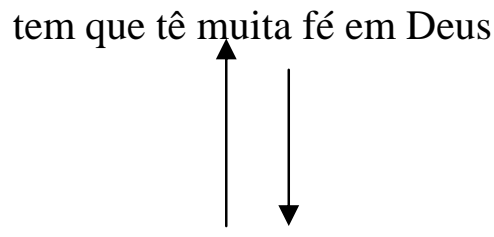

eu vô operá e vô fica boa né?

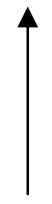

eu falei que queria

se eu num operasse ( ) ia passá prus pulmão
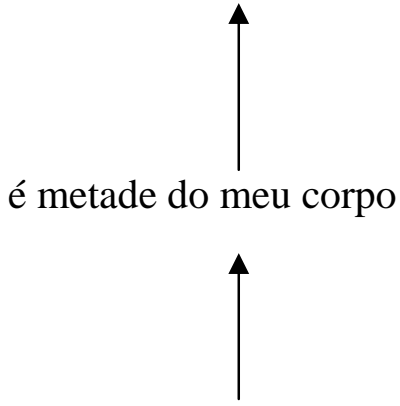

a gente fica pensativa né num sabe se a gente vai vivê vai morrê

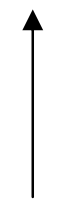

pra gente se cuidá né? cuidá da doença da gente né...

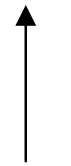

admissão hospitalar 


\section{Participante 10}

Maria é uma mulher de sessenta e um anos, é procedente de Ribeirão Preto, SP, não completou o ensino fundamental, é viúva, trabalha em casa, passou por duas gestações e dois partos. Teve como proposta cirúrgica uma tumorectomia com ampliação de margem.

Maria chegou sozinha à enfermaria, no trajeto até o quarto, relatou que não queria ficar internada no dia de hoje porque sua filha, que havia retirado uma das mamas recentemente, precisava muito dela.

Após a enfermeira sair do quarto, convidei Maria para participar deste estudo, que somente ocorreu após seu aceite via termo de consentimento pós-informação (ANEXO D).

No decorrer da entrevista Maria deixou transparecer sua preocupação e emoção em ter deixado uma de suas filhas em casa, que também foi operada por causa de um câncer de mama. Relatou ainda que estava tranqüila e esperançosa quanto sua cura e de sua filha também. 


\section{MAPA 10}

Maria

$\begin{array}{lll}\text { chegada ao hospital } \quad \text { separação } \quad \text { cirurgia } & \begin{array}{l}\text { participação na decisão e/ou } \\ \text { desconhecimento da cirurgia }\end{array}\end{array}$

\section{dá um pouquinho de ner-vo-so \\ dia normal}

fico impaciente

((chorou)) foi

ruim...

\section{seja o que Deus quizé...}

eu acho aqui ma-ra-vi-lhoso... ( ) o hospital os

funcionário dos médico eu num tenho queixa de NIN-

GUÉM

tô cheia de esperança...

esperança que o meu num é

nada

um pouco assim

preocupada... não comigo

com quem tá em casa... eu pedi pra doutora não me dexá aqui porque às veze a gente fica amolano os vizinho

eles falam quelóide né? pra mim num havia nem necessidade mais eles querem tirá en-tão eles sabem mais do que eu... então tem que tirá

\section{Deus}


GRÁFICO 10

Maria

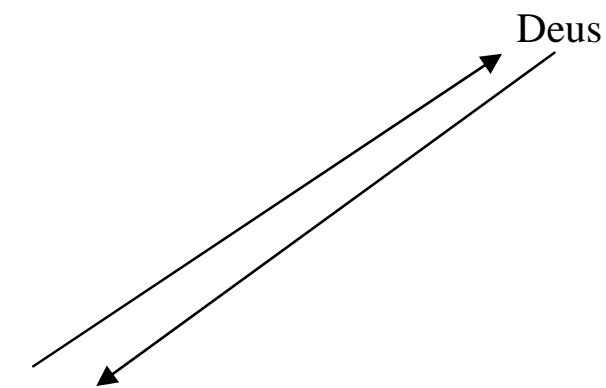

às veze a gente fica amolano os vizinho

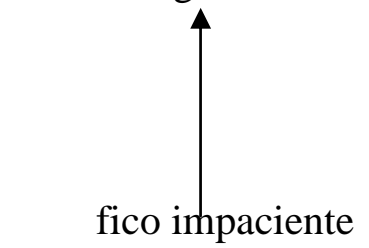

$\uparrow$

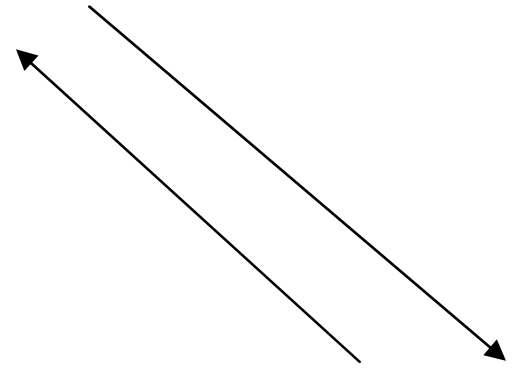

um pouco assim preocupada... não comigo com quem tá em casa tô cheia de esperança

dá um pouquinho de nervoso

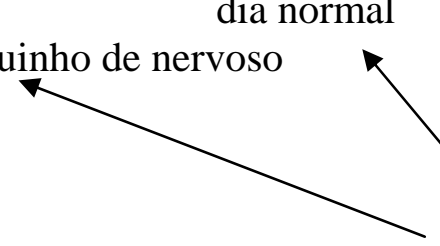
eles falam quelóide né?

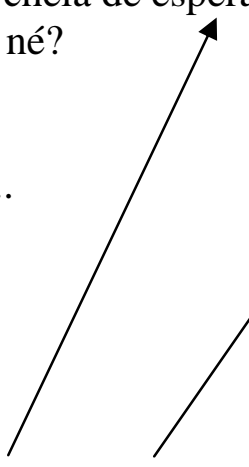

admissão hospitalar 


\section{DISCUSSÃO DOS RESULTADOS}

\section{Participante 1}

O gráfico referente ao discurso da primeira entrevistada mostra que as representações que essa mulher possui em relação ao momento da admissão hospitalar estão centradas em dois eixos principais, que são: conceber o hospital como um local esquisito e de difícil entrada porque isso representa ter que lidar com a perda da mama, o que desperta sentimentos de aborrecimento e tristeza. Mas que são atenuados ao depositar sua confiança nos médicos e em Deus.

Enfrentar o difícil momento da chegada ao hospital para essa mulher está colocado no outro, isso significa depositar no externo a força para não desistir de passar pela cirurgia por câncer de mama. Ao ter o externo como fonte de segurança significa enfrentar a própria situação de estar doente com alteridade, parece não haver a possibilidade da busca desse suporte no mundo interno dessa mulher. Talvez porque fazer incursões internas requer um grau de amadurecimento que no momento ela parece não possuir. Além disso, ao existir a implicação do sujeito em seu real estado é muito doloroso, e em momentos já sofridos como parece ser o da chegada ao hospital para essa mulher, o mais esperado é que o sujeito se utilize de formas de enfrentamento que sejam condizentes com o que é mais suportável psicologicamente, nem que essas formas sejam as consideradas menos saudáveis. 
Parece haver um comportamento de submissão nessa mulher no que diz respeito à cirurgia. Afirma que operará porque já está no hospital mesmo, não busca querer participar da decisão de operar ou não, diz que se submeterá à cirurgia porque pode ser que ficar com o câncer (esse negócio) pode ser pior.

A submissão também pode estar evidenciando uma reprodução do modelo de cuidado que era prestado às mulheres com câncer no Século das Luzes. Modelo que excluía as mulheres doentes de câncer do convívio em sociedade, que diria do direito de participação no tratamento a que nem muitas vezes chegavam a receber. As mulheres eram vistas como vítimas e como as únicas responsáveis em suportar o sofrimento do câncer até a morte (Dias, 1997; Sant’Anna, 1997).

Em relação à cirurgia ainda, no momento da entrevista, ela relatou a história de uma vizinha que não se tratou de um câncer de mama e faleceu por causa dele. Essa história lhe tocou bastante e parece ter levado essa participante a um processo de elaboração, o que resultou na sua atitude de se cuidar.

O medo do sofrimento e da morte relacionados ao câncer permeia essa mulher ao verbalizar que pode ser pior permanecer sem passar pela cirurgia por câncer de mama. Demonstrando o quanto o diagnóstico de câncer, para essa mulher, pode ainda estar ligado a receber uma sentença de sofrimento e morte.

Além do estigma de ter recebido uma sentença de morte não houve durante toda a entrevista a menção, por parte dessa mulher, à palavra câncer. Este foi sim tratado como sinônimo de negócio.

Pensando no significado da palavra negócio, negação ao ócio, pode-se compreender que essa participante concebe o câncer como algo que implica em trabalho, trabalho talvez de ter que sair da rotina e das atividades da vida diária e ter que assumir, pelo menos temporariamente, outras atividades, como as saídas de casa para ir às consultas médicas. Trabalho de ter que passar a pensar ou agir de formas diferentes para lidar com a situação estressante que o câncer representa, o que implica em todo um processo de se ver de frente com conceitos construídos socialmente em relação ao que é ser uma pessoa que recebeu um diagnóstico de câncer de mama e como é viver a partir desse fato. 


\section{Participante 2}

O gráfico dois mostra as representações da segunda entrevistada em relação à sua admissão no hospital necessária para a realização da cirurgia por câncer de mama. Para essa mulher chegar ao hospital representa um momento difícil, deixando-a abalada e causando comoção. O que a leva ter vontade de sair correndo e nem operar. Entretanto, essa possível fuga não é concretizada porque há o fortalecimento em Deus.

Percebe-se que essa participante está integrada com a representação que ela possui da sua entrada no hospital, que é de ser difícil, e com o que ela sente, emoção e sentir-se abalada. Essa integração demonstra um certo grau de amadurecimento psicológico nessa participante, porque ela verbaliza aquilo que realmente a chegada ao hospital lhe desperta.

Apesar de demonstrar amadurecimento ao estar integrada entre o que pensa e o que sente, a presente entrevistada não parece estar ainda madura para se implicar na situação de enfrentamento. Ao buscar recursos para lidar com a situação de internação volta-se apenas para o externo, coloca Deus como seu provedor de recursos para enfrentar o momento da chegada ao hospital.

A admissão hospitalar, para essa mulher, desperta uma necessidade de fuga do ambiente hospitalar, o que parece ir ao encontro de uma das funções do hospital quando criado: a de um lugar reservado para as pessoas morrerem (Foucault, 1979).

A necessidade de fuga também parece ter sido produzida pelo contado que ela mantém, relatado durante a entrevista, com uma amiga que recebeu o diagnóstico de câncer de mama e está com metástase no fígado e na coluna. E que, também, tem dificuldades em movimentar o braço do lado operado. Essa possível perda de função parece ter sido um outro motivador para essa participante querer ir embora do hospital.

O mapa dois mostra que a representação que essa entrevistada possui do câncer é de um negócio que possui raiz. Assim como a primeira entrevistada, o câncer, para essa participante implica em trabalho. Mas, essa segunda entrevistada 
associa o trabalho a uma raiz. A palavra raiz possui vários significados, entre eles, a parte oculta de um acontecimento (Ferreira, 1986; Rocha \& Pires, 2000).

O câncer, para essa participante, parece representar ter que lidar com alguma mágoa. Isso vai ao encontro do que a literatura coloca em relação à formação psicológica das doenças: a de que sentimentos represados durante longos períodos da vida podem, associados a uma baixa imunidade física, e a um evento estressante bastante significativo, predispõe o indivíduo ao desenvolvimento de alguma doença (Simonton, 1987).

A submissão também se faz presente nessa mulher em relação à opção de realizar ou não a cirurgia por câncer de mama. Em momento algum da entrevista ela se mostrou voltada a participar dessa decisão. Mais uma vez há a repetição do modelo de cuidado a que as mulheres eram submetidas no passado quando do acometimento pelo câncer de mama. Modelo que as excluía e as culpava pela sua condição (Sant’Anna, 1997). 


\section{Participante 3}

O gráfico três mostra a representação que a terceira entrevistada possui em relação à sua admissão hospitalar necessária para a realização da cirurgia por câncer de mama. Para ela a chegada ao hospital representa tirar um peso, tirar uma doença. O que a leva não ter medo, sentir paz e tristeza. É um momento que ela quer que acabe logo. Momento que ela enfrenta depositando a confiança em si mesma.

Representar a admissão hospitalar enquanto sinônimo de ficar livre da doença parece evidenciar que a internação e conseqüente cirurgia serão capazes de curá-la. Isso significa tratar com alteridade a resolução do seu caso, e também é uma representação que mostra a desinformação dessa participante no que diz respeito a todas as etapas do tratamento a que possivelmente terá que se submeter.

A alteridade pode ser reconhecida nessa participante ao colocar no hospital a responsabilidade pela sua cura. Mas, essa alteridade não se faz presente quando ela afirma que a confiança para enfrentar esse momento tem de ser buscada nela mesma.

Ao verbalizar que não está com medo, está sentindo paz, tristeza e vontade de ir embora rapidamente parece significar que essa participante está diante de um conflito. A tranqüilidade estabelece-se na medida em que ela se vê diante da possibilidade de cura, entretanto, sente medo, tristeza e quer que isso acabe logo porque talvez a representação que essa entrevistada possua do hospital é de que ele seja um local de sofrimento e morte. Dessa forma fica incongruente ficar tranqüila num local que foi criado para acolher as pessoas para morrerem.

Ao tocar na questão do câncer há associação dele como um carocinho que costuma enraizar. O câncer, para essa entrevistada, está relacionado a algo que cria raiz. Entendendo o termo raiz como a parte de um acontecimento oculto, (Ferreira, 1986; Rocha \& Pires, 2000) emerge, assim como para a segunda entrevistada, a relação entre câncer e um acontecimento mal elaborado pelo sujeito, que por não ter encontrado meios saudáveis de resolução, ao se unir a algum evento estressante e a uma baixa imunidade do indivíduo, pode desencadear o desenvolvimento de alguma doença. 
No que toca a questão da cirurgia, essa mulher não participou também da resolução de se submeter a ela ou não. Talvez porque, para ela, a cirurgia representa a cura. Assim, não há sentido em questionar um procedimento que significa a resolução completa de um problema de saúde.

A cirurgia, para essa entrevistada, além de representar a cura, significa também retirar uma parte do corpo que parece ter perdido sua conotação sexual. Ela relata o término do sucesso que pôde fazer com seus seios, restando apenas doença, o que novamente justifica para ela a necessidade da cirurgia. 


\section{Participante 4}

A quarta entrevistada, como mostra o gráfico quatro, representa sua chegada ao hospital para se submeter à cirurgia por câncer de mama como um meio de solucionar seu problema. Apesar de conceber o hospital como um local não muito bom, mas que a faz se sentir bem, despertando na mesma segurança, otimismo e emoção. Momento que ela enfrenta com o apoio de suas crenças, dela mesma, da sua família e de seu namorado.

Nessa participante, a presença dos sentimentos de segurança e bem-estar parecem ser conseqüência da representação de que a admissão hospitalar será suficiente para a resolução do seu caso. Essa representação parece mover essa entrevistada ao ponto de não se incomodar com o ambiente não muito bom no qual tem de permanecer e com a emoção que sente.

Além da representação de que tudo será resolvido, essa mulher tem uma rede de suporte muito vasta e bem estabelecida para apoiá-la em suas necessidades. Ela se vê apoiada tanto por condições externas como suas crenças, sua família e seu namorado, tanto quanto pelos recursos que ela busca dentro de si e que a fazem acreditar que tudo será superado. Por tudo isso, a admissão hospitalar pode não ser algo que lhe desperta medo e sofrimento.

A presente entrevistada, como pode ser observado no mapa quatro, afirma que está feliz. Felicidade que não provém da representação que ela faz da admissão hospitalar, mas sim do namorado que encontrou há três meses atrás e a quem atribui a mudança de sua vida.

Apesar de demonstrar condições internas para enfrentar o momento da admissão hospitalar, não houve indícios de amadurecimento, nessa entrevistada, para se implicar com a decisão de se submeter à cirurgia por câncer de mama. Na verdade, ela coloca que a filha foi sua interlocutora tanto na busca e divulgação do resultado da biópsia à família, quanto na negociação da cirurgia.

A dificuldade de contato com seu real estado de saúde também é revelada pelo não mencionamento da palavra câncer em nenhum momento da entrevista ou observações realizadas. 
Mais uma vez a alteridade pode ser reconhecida. Parece ser muito doloroso, assim como para as outras participantes, admitir que está doente. Muito mais difícil admitir que essa doença se chama câncer. Palavra que parece ser a presença de uma ausência.

A presença de uma ausência, nessa entrevistada, parece estar marcada pela cadeia de significantes presentes na cultura (Lacan, 1988). Influência que o sujeito tem a ilusão de não ser comandado por ela (Authier-Revuz, 1990), mas que não deixa de ser apenas uma ilusão.

Nessa entrevistada, parece que a cultura, a Lei que os povos sempre seguiram em relação ao câncer de mama a atravessa. A Lei do não dito, do não assumido, a ausência que se fizesse presença submeteria essa mulher muito mais a julgamentos e conseqüentes abandono e solidão. 


\section{Participante 5}

O gráfico que apresenta as representações sociais da quinta entrevistada demonstra que essa mulher representa o chegar ao hospital para se submeter à cirurgia por câncer de mama como um momento de cuidado para sua saúde. O hospital é um local onde ela foi bem recebida e bem tratada. Porém, a presente entrevistada relata ter trauma e medo de cirurgia, que parecem ser atenuados ao conceber que a cirurgia é uma complementação do seu tratamento. Além disso, pensar nas pessoas que já passaram pela mesma cirurgia que ela terá de passar, outros que lhe deram força, sua fé em Deus e sua coragem, confiança e força de vontade foram formas de enfrentamento utilizadas por essa participante para dar entrada no ambiente hospitalar e ali permanecer por um período.

A representação da admissão hospitalar como cuidado para a saúde, trazida por essa participante, aponta que ela não parece conceber seu problema, o câncer, como somente uma doença porque afirma que receberá um cuidado para sua saúde. O que significa entender que necessita de algo mais globalizado que vai além da perspectiva de que apenas retirar a mama será a solução para seu caso.

Para essa participante, o câncer, significa algo que apenas o corpo físico demonstra como conseqüência de um sofrimento que ela não consegue localizar. Um sofrimento que ela não conseguiu colocar por meio da palavra, por isso utilizou-se do corpo, tratado como alteridade para falar.

A impossibilidade de falar por meio da palavra repetiu-se mais uma vez ao não verbalizar a palavra câncer. Por meio de sua presença física num local onde, dentre outros casos, chegam mulheres semelhantes a ela, não houve porque dizer, mas sim seu corpo foi utilizado enquanto palavra.

As formas de enfrentamento utilizadas por ela estão assentadas preferencialmente nos outros, como Deus, nas pessoas que passaram por situação semelhante e em pessoas que a apoiaram, bem como nela também. Aliás, por ter uma rede de suporte continente pôde chegar ao hospital sozinha, apesar de relatar ter trauma de cirurgia. 
A decisão de se submeter à cirurgia por câncer de mama, como mostra o mapa cinco, iniciou-se no momento em que lhe foi colocado que fazer a cirurgia era necessário. Ela então teria que resolver e parece que há o entendimento de que a cirurgia é para o seu bem porque é uma complementação do seu tratamento. 


\section{Participante 6}

A sexta entrevistada como pode ser verificado no mapa seis, representa sua chegada ao hospital para ser submetida à cirurgia por câncer de mama como algo muito bom porque desperta na mesma a esperança de ficar curada. O hospital é um local ótimo, onde ela se sente bem tratada, entretanto, o ambiente hospitalar não é bom também pelo fato de que as pessoas não gostam de se internar e muito menos ainda de passar por uma cirurgia. Essa entrevistada, com o intuito de enfrentar esse não gostar e conseqüente operar, pensa em oração e em Deus.

A representação de que a admissão hospitalar pode significar sua cura parece evidenciar que a cirurgia pode ser a única forma de tratamento capaz de trazer a cura do câncer.

Depositar na cirurgia uma possível cura não deixa de ser tratar o próprio câncer com alteridade. Isso significa não haver por parte dessa participante sua implicação com seu real estado de saúde e nem com o quanto ela também pode contribuir com sua recuperação.

A alteridade parece se presenciar nessa mulher quando surge a necessidade de falar de situações difíceis. Falar do hospital implica em não utilizar o pronome de primeira pessoa do singular, são as pessoas que não gostam de se internar e nem de passar por uma cirurgia.

Ao tocar no que significa o câncer, não há a menção ao mesmo. O câncer é tratado como uma doença, uma coisa que não se pode deixar. Esse deixar parece trazer consigo a significação de que o câncer, se não tratado, pode tomar conta do corpo e levar à morte.

As estratégias de enfrentamento utilizadas por essa entrevistada também estão depositadas no outro. Deus está em primeiro lugar em sua vida, o que evidencia novamente sua não implicação com o fato de ter recebido um diagnóstico de câncer de mama, o que a impossibilita de utilizar estratégias de enfrentamento presentes nela mesma.

Como Deus é seu guia principal que ilumina até mesmo os médicos (vide mapa 6), ao receber a notícia de que precisava passar pela cirurgia por câncer de 
mama concordou sem questionamentos. Concordou pelo fato de que era alguém iluminado por Deus que estava the comunicando a necessidade da cirurgia. 


\section{Participante 7}

A sétima participante, como demonstra o mapa sete, representa sua chegada ao hospital para ser submetida à cirurgia por câncer de mama como um momento muito difícil que implica em obrigação de sua presença. Por isso, relata que tem vontade de ir embora e procura não pensar no que está acontecendo. Conta pensar muito na cirurgia, em possíveis reações da anestesia. Mas, pensa em Deus e confia na convivência que sempre procurou ter com pessoas brincalhonas e capazes de passar energia boa para as outras para enfrentar esse momento.

A presente entrevistada assume que não é fácil entrar em um hospital para se submeter a uma cirurgia por câncer de mama. E por ser doloroso entrar em contato com o quanto essa chegada é difícil utiliza-se de mecanismos defensivos como uma possível fuga, assim como a segunda entrevistada, e o procurar não pensar.

A preocupação com a cirurgia é central, principalmente com possíveis reações à anestesia. Essa preocupação pode significar que essa mulher possui um medo de morrer muito grande, que pode ser efeito de uma das funções do hospital quando de sua criação, a de um lugar reservado para a morte (Foucault, 1979). E ela então tenta se defender da possibilidade da própria morte, pensando em fugir e procurando não pensar.

As formas de enfrentamento utilizadas por essa participante, além do tentar se manter distante do que a cerca, são também Deus e a esperança de que a convivência que procurou ter com pessoas que brincam e que passam energia aos outros lhe trarão alento.

Essa entrevistada enfrenta o momento da admissão hospitalar tratando-a com alteridade e confiando nas relações que tentou estabelecer ao longo de sua vida com pessoas significativas.

A despeito de ter entrado em contato parcialmente com o momento da admissão hospitalar, isso não ocorreu com a questão do câncer e nem mesmo com a participação na decisão de realização da cirurgia. O câncer parece ter relação com algo que se enraíza, como foi verbalizado também pela primeira, segunda e terceira entrevistadas, raiz que tem que ser extirpada completamente para que o mal não permaneça em seu corpo, e por esse motivo não questionou a necessidade da cirurgia. 


\section{Participante 8}

O gráfico de número oito apresenta as representações sociais da oitava participante em relação à sua admissão hospitalar necessária para a realização da cirurgia por câncer de mama. Essa chegada ao hospital representa ficar livre de uma dor, bem como há a representação de um momento em que será necessário fazer um tratamento medicamentoso para depois operar. A certeza de que a dor não existirá mais lhe permite permanecer com a cabeça leve, mas também lhe desperta medo, medo de agulhas e mais ainda, medo de sangue. Porém, Deus e os médicos são utilizados como estratégias de enfrentamento para enfrentar esse momento.

A chegada ao hospital também remete essa participante à questão da perda da mama. Assim como a terceira entrevistada, ao falar do significado da mama, parece estar contando sobre a perda da conotação sexual de suas mamas, ao relatar que não terá mais proveito com elas, porque o que resta agora é só o câncer.

A representação da admissão hospitalar como sinônimo de resolução do câncer de mama novamente é verbalizada por essa participante, bem como ocorreu nos discursos da terceira, quarta e sexta entrevistadas.

Essa participante, ao representar a chegada ao hospital como sinônimo de ficar livre de uma dor, parece estar contando sobre o significado que o câncer de mama tem em sua vida. O significado de algo que não é possível ser localizado, algo que lhe causa um desconforto, que aparece cifrado de forma enigmática, assim como para a quinta entrevistada.

O significado do câncer como algo doloroso parece ainda ter relação com o fato de sua mãe também ter tido câncer de mama. Dessa maneira, ser admitida no hospital devido à mesma doença que um dia acometeu sua mãe, pode ter levado essa participante a entrar em contato com o quanto foi difícil ter acompanhado sua mãe naquelas circunstâncias, que hoje são as suas também.

A alteridade também se faz presente nessa participante tanto em relação à sua não implicação nessa dor, como também na escolha de suas estratégias de enfrentamento, sustentadas em Deus e nos médicos. 
A decisão para realização da cirurgia mais uma vez ocorreu, assim como nas escolhas de suas formas de enfrentamento, de forma desvinculada de si mesma, o médico comunicou-a que a cirurgia tinha que ser feita e ela aceitou, ou seja, ela permitiu que o médico escolhesse por ela. 


\section{Participante 9}

As representações sociais relacionadas à admissão hospitalar para a realização da cirurgia por câncer de mama, da nona participante, estão demonstradas no gráfico de número nove. Para essa entrevistada a chegada ao hospital representa um cuidado para si, mais especificamente um cuidado para sua própria doença. Essa representação desperta-lhe incerteza quanto sua sobrevivência e faz emergir o questionamento da eficácia da cirurgia para sua cura. Mas, a fé em Deus é seu suporte para passar por essa entrada no hospital e conseqüente cirurgia.

A admissão hospitalar, para essa mulher, representa um cuidado muito mais para uma parte de si mesma, sua doença, do que para sua globalidade enquanto sujeito. Apesar de ser um momento que significa cuidado para o câncer de mama, como pode ser verificado ainda nos discursos da terceira, quarta, sexta e oitava entrevistadas, cria porém a incerteza quanto à cura do câncer. O que pode significar que essa participante, diferentemente das já citadas, não concebe a internação como uma solução completa para seu problema de saúde.

O ser hospitalizada, bem como para a segunda e sétima entrevistadas, também significa a incerteza de permanecer viva, o que vai ao encontro da função primeira do hospital, quando foi criado: a de um local onde as pessoas entravam para morrer (Foucault, 1979).

Para essa participante, o momento da admissão hospitalar, enquanto incerteza de continuidade da vida ainda pode estar relacionada, como constatado no decorrer de sua entrevista, às perdas futuras da mama, do neto que ficou em casa e do marido, falecido há três meses. Isso pode significar que essa entrevistada está questionando se esse momento não está reservado para ela falecer também, porque está sem as pessoas que ela parece mais amar e perderá ainda uma de suas mamas.

As incertezas de cura e sobrevivência que assolam essa entrevistada são o que a admissão hospitalar desperta-lhe no seu íntimo, contudo, são atenuadas pela sua fé em Deus. Talvez, o fato de ser tão doloroso entrar em contato com a possibilidade da própria finitude, explique a escolha de um outro como estratégia de enfrentamento para entrar no hospital e se submeter à cirurgia por câncer de mama. 
A decisão para a realização da cirurgia (vide mapa nove) partiu da participante em questão. Entretanto, parece ter sido uma decisão movida pelo medo dela de que o câncer é uma doença que se instala, vai se disseminando até levar a pessoa à morte. Aliás, essa concepção do câncer, enquanto uma doença que vai minando as energias de uma pessoa por dentro, era presente já no século XVIII na Europa e, nas primeiras quatro décadas do século XX, no Brasil (Sant’Anna, 1997). 


\section{Participante 10}

O modo como a décima participante representa sua chegada ao hospital para se submeter à cirurgia por câncer de mama pode ser visualizado no gráfico de número dez. Essa chegada ao ambiente hospitalar representa um dia normal em sua vida, o qual ela considera um local maravilhoso que, mas que lhe desperta um pouco de nervosismo, preocupação e impaciência, que são enfrentados com a ajuda de Deus. Momento este em que ela se sente esperançosa em não estar com câncer.

A forma como a presente entrevistada se coloca no mundo parece estar ligada ao que o outro necessita, que pode ser percebida quando ela chora por ter sido ruim deixar alguém em casa e relata ter pedido para não ficar internada porque pode estar perturbando algum vizinho.

A submissão em função do desejo do outro também pode ser percebida no momento em que foi comunicada sobre a necessidade da cirurgia (vide mapa dez), ela verbaliza que não via necessidade porque lhe disseram que era uma quelóide, entretanto, como considera os médicos mais sábios que ela, não há o que contestar.

O câncer, para essa entrevistada, é equivalente a uma quelóide, que de forma geral, é uma cicatriz visível que muitas vezes remete a um acontecimento doloroso e, este parece ser o significado do câncer de mama na vida dessa mulher. Ela parece ter vivido algo doloroso que lhe deixou uma marca que, por ela, não seria esquecida.

A marca que o câncer parece ter deixado na vida da presente participante pode estar relacionada à sua filha, que recentemente recebeu o diagnóstico de câncer de mama e ainda não se recuperou da cirurgia porque teve também uma leucopenia. Essa entrevistada parece não ter tido tempo suficiente para se recuperar do impacto que o diagnóstico de câncer de sua filha lhe causou. Parece que por não ter havido esse tempo necessário, não foi possível também para essa mãe entrar em contato com o que estava acontecendo agora consigo mesma.

Assim, entende-se também sua não implicação no enfrentamento da admissão hospitalar. Enfrentar o momento da entrada no hospital pensando em Deus lhe enche de esperança (vide mapa dez). 


\subsection{REPRESENTAÇÕES SOCIAIS}

As representações sociais em relação ao câncer de mama, reunidas a partir da análise dos mapas associativos e gráficos das participantes deste estudo, mostram que esse grupo de mulheres representa o câncer de mama como um negócio que enraíza, um peso, uma doença, uma dor, um problema e uma marca. Esses significados parecem apontar para o sofrimento que significa o câncer de mama na vida dessas entrevistadas.

A relação dos significados do câncer de mama com o tratamento cirúrgico, no momento da admissão hospitalar apresenta vários conflitos para o grupo de mulheres entrevistado.

O conflito fica estabelecido na medida em que essas entrevistadas percebem o câncer como algo significativo em suas vidas e que necessita de cuidado, representado pela cirurgia. Entretanto, é um procedimento representado no momento da internação enquanto: perda da mama (participante 1), medo da morte (participantes 2, 7 e 9), cura (participantes 3, 4, 6 e 8), o cuidado enquanto estratégia de retorno à saúde (participante 5) e dia normal (participante 10). Isso significa que a cirurgia é um procedimento que pode ajudar na resolução do câncer de mama, mas, ao mesmo tempo é algo desconhecido e que acarreta o lidar até com uma possível morte.

Cada categoria definida anteriormente, como capaz de significar as representações sociais desse grupo de mulheres em relação à admissão hospitalar, 
será apresentada com o objetivo de que possa haver uma compreensão mais aprofundada de cada uma delas.

A representação perda da mama pode ser compreendida a partir do complexo de castração e da história do significado do seio e do câncer no decorrer da história. Entendemos que esses são elementos capazes de dar sentido à representação da admissão hospitalar como sinônimo da perda da mama.

A expressão complexo de castração, consultada nas edições brasileiras de 1980 (a) e (b), foi utilizada pela primeira vez por Freud em um artigo seu de 1908 intitulado: "Sobre as teorias sexuais das crianças". Artigo que antecipa muitas descobertas suas sobre o complexo de castração e que se baseia no caso do pequeno Hans de 1909.

O termo castração significa a experiência psíquica completa, vivida pela criança aproximadamente aos cinco anos de idade e que a leva a assumir sua identidade sexual futura. Entretanto, é uma experiência angustiante, na qual a diferença anatômica entre os sexos é reconhecida (Nasio, 1996).

Apesar do complexo de castração fazer parte da evolução sexual infantil, não há sua estagnação a esse período cronológico. Essa experiência inconsciente é sempre renovada ao longo da vida, que é admitir mesmo com dor que o corpo possui limites mais estreitos do que os limites do desejo (Nasio, 1996).

O complexo de castração na menina passa por vários momentos. No primeiro tempo não há a percepção da diferença entre os sexos e nem mesmo a percepção da presença de seu próprio órgão sexual, no caso, a vagina. A característica mais marcante desse tempo é a crença de que todo mundo tem um pênis (Nasio, 1996).

No segundo tempo a menina descobre visualmente o pênis, que pode ocorrer através de um parente próximo ou de um colega de brincadeira, nesse momento surge a inveja porque o pênis, para a menina, é a réplica superior de seu clitóris, e assim ela torna-se vítima da inveja do pênis, que é a inveja de possuir o que viu e do qual foi castrada (Nasio, 1996).

O terceiro tempo é marcado pelo reconhecimento, na menina, de que não é só ela que é castrada, mas, todas as outras mulheres também e, inclusive sua mãe. Por isso, essa passa a ser rejeitada pela filha por não ter lhe transmitido atributos fálicos e nem mesmo ter ensinado-lhe a valorização de seu verdadeiro corpo de mulher. Sendo 
assim, o ódio primeiro ressurge, esse ódio é fruto do ressentimento de insatisfação da mulher quando separada da mãe no desmame. E, pelo fato de ter descoberto que a mãe é castrada, a menina então é levada a realizar uma segunda separação, o que a predispõe a escolher o pai como objeto de amor (Nasio,1996).

O tempo final do complexo de castração culmina com a escolha da menina em decidir sobre o destino de sua feminilidade. Essa tomada de posição pode ser feita em relação a três saídas.

Na primeira saída há uma negação total da existência do pênis, o que faz com que essa menina não entre em contato também com a inveja dele (Nasio, 1996).

A segunda saída para a feminilidade caracteriza-se pela crença da menina em um dia ter um pênis do mesmo tamanho que viu. O objetivo de sua vida é a fantasia de ser homem, o que pode até culminar numa homossexualidade (Nasio, 1996).

Na terceira saída, considerada "normal”, a menina reconhece sua castração, por isso, muda seu objeto de amor de sua mãe para seu pai, o que possibilita sua entrada no complexo de Édipo. Essa mudança de objeto de amor implica num deslocamento da libido no corpo feminino, que passa progressivamente do clitóris para a vagina no período da infância à adolescência. E, essa passagem é traduzida pela vontade da mulher em ser mãe (Nasio, 1996).

Diante do que foi exposto sobre o complexo de castração é possível entender o quanto deve ter sido angustiante para essa entrevistada ter entrado no hospital para se submeter à cirurgia por câncer de mama. Essa angústia parece ter sido intensa porque essa participante teve que reviver a castração não apenas psiquicamente, mas, fisicamente também porque a perda da mama era real.

Essa entrevistada parece ter tido que lidar com momentos muito dolorosos. O primeiro deles, que mobiliza os sentimentos mais primitivos é o próprio complexo de castração, revivê-lo significa vivenciar novamente o modo como estabelecemos nossas primeiras relações no mundo, que são as relações com nossos pais e, além disso, significa, no caso de uma mulher, reviver que saída para a feminilidade foi escolhida.

Um outro momento bastante difícil parece ser enfrentar o que socialmente foi instituído enquanto significado dos seios. Os seios, como apresenta Yalom (1998), ocupam uma posição central na história da humanidade. Até o século XIX eles eram 
a garantia de sobrevivência dos recém-nascidos porque não havia ainda a pasteurização do leite, assim, o leite materno era a única fonte de leite disponível para aqueles que vinham ao mundo.

Na sociedade grega o seio aparecia, através das lendas, como possuindo poderes sobrenaturais. A presença dos seios também pode ser verificada em esculturas, como um vaso encontrado na Europa por volta de 1300 A.C., composto por vários seios à sua volta e, imagens cultuadas pelos cristãos até o surgimento do Islão no século VII D.C., nas quais os seios eram amparados nas mãos e braços das imagens (Yalom, 1998).

A representação perda da mama também está relacionada aos conceitos que sempre existiram em relação ao câncer ao longo da história, como Hipócrates (460377 A.C.), que acreditava existir uma associação entre a origem do câncer de mama e o término da menstruação. A relação existente era de que o princípio da menopausa causava um encaroçamento dos seios, que finalizava com o câncer (Yalom, 1998). Houve a associação também do câncer com a falta de limpeza do corpo e da alma, entre 1900 e 1930, ao ser comparado à forma de contágio da sífilis, como ainda a relação do câncer ao sacrifício e à purificação (Sant’Anna, 1997). Na França, no início da Idade Média, havia uma pintura na qual a luxúria era representada por uma forma de mulher que transpassava seus seios com uma lança. Uma outra representação da luxúria é a de uma mulher no inferno que tinha um sapo sobre seus seios e seu púbis em chamas (Yalom, 1998). As pessoas também acreditavam que tocando os corpos das mulheres com câncer estavam obtendo um estoque de pureza para si. Após 1930 o câncer passou a ser conceituado como uma doença causada por células malignas do próprio doente (Sant’Anna, 1997).

Sanhueza Alvarado (1999) ao analisar o significado da mama para quatorze mulheres mastectomizadas identificou cinco temáticas principais, que são: 1) a mama como simbologia erótico-sexual; 2) a mama enquanto nutrição do recém-nascido; 3) o significado dela no processo de socialização, e 5) a mama em relação ao cuidado de si. Essas cinco temáticas foram analisadas a partir de uma abordagem interacionista, permeada pelo enfoque das relações de gênero, o que evidenciou que as participantes desse estudo estavam e estão marcadas pelos esteriótipos da sociedade patriarcal, na qual as mulheres eram conduzidas à realização dos serviços 
domésticos, à exclusão da vida política e, a esconderem seus corpos da cabeça aos pés (Yalom, 1998).

O lidar com a futura perda da mama ou mesmo de parte dela pode levar a mulher a uma alteração de sua auto-imagem, pelo fato da mama ser um símbolo de sensualidade. Essa alteração pode despertar na mulher sentimentos de inferioridade e o medo da rejeição (Wanderley, 1994).

A perda real de uma mama para essa participante parece ter sido um acontecimento doloroso, porque implicou em reviver um limite do corpo nele mesmo, que é um encontro que passa do plano inconsciente para o plano consciente de uma forma física, concreta e isso não é fácil de ser vivido nem inconscientemente, que diria conscientemente. Além disso, perder uma mama também implica na perda de parte de um lugar que foi construído socialmente para as mulheres.

Um outro significado relacionado ao tratamento cirúrgico no momento da admissão hospitalar para a realização da cirurgia por câncer de mama foi o do medo da morte, o que aponta para um outro conflito que algumas das mulheres entrevistadas tiveram que enfrentar, ou seja, a internação era necessária para a realização da cirurgia, mas, era também um acontecimento que podia lhes tirar a vida.

A definição do que seja a morte é apresentada por Barbarin (1997) como algo impossível porque é algo que nosso intelecto é incapaz de explicar. Nosso inconsciente não tolera a idéia de que possamos ter um fim real (Kubler-Ross, 1996).

Ainda que seja impossível a definição do que realmente seja a morte, Barbarin (1997), tenta aproximar-se dela afirmando que a morte é uma evolução, uma certeza, uma mudança e uma ausência. Concluindo que o que há é ausência de vida, escuridão e silêncio.

O fato de não suportarmos a possibilidade de um fim real para nossa vida na Terra, nos leva a crer que para morrer necessitamos de uma causa que não possamos controlar, o que implica em algo doloroso que nega a possibilidade de uma morte causada por algo natural (Kubler-Ross, 1996).

Entender a morte como algo que só pode ser sofrido já parece explicar o motivo de termos medo ou fobia dela. Gaiarsa (1999) desenvolve a questão da fobia, palavra proveniente do grego que significa medo, como o resultado de dois 
movimentos do sujeito, que são: o de projeção de um impulso e sua conseqüente regressão. No primeiro movimento o impulso é colocado pelo indivíduo em algum lugar, mas, no segundo movimento o sujeito foge dele porque ele é assustador. Entretanto, há explicações outras para o surgimento desse medo.

Barbarin (1997) defende a hipótese de que nossa civilização introduziu em nós a noção do horror juntamente com a noção de inteligência, acreditando que com isso estava ensinando a vida aos homens. Mas, foi um ensinamento que trouxe o horror da morte transformando-a em algo horrível.

Durante a Idade Média a morte era vivenciada de uma forma bastante tranqüila. Ela acontecia dentro de casa, com a participação tanto daquele que estava prestes a morrer quanto de sua família. O moribundo entendia a morte como algo inerente à vida (Ariès, 1977; Santos, 1993).

Entretanto, com a solidificação do pensamento ocidental, a morte passou a ser negada. $\mathrm{O}$ aparecimento da burguesia instituiu a separação entre o corpo e a alma, a vida e a morte, assim esta deixou de ter seu espaço (Santos, 1993). Essa falta de um lugar para a morte foi conseqüência das duas formas primeiras de medo da morte, que segundo Ariès (1977), foram: o medo da morte aparente, que era o medo de um estado de insensibilidade semelhante à morte e à vida e, a repugnância, presente em dois momentos, o primeiro seria em representar o morto e seu cadáver e depois, seria a repugnância em imaginar essas cenas.

A resposta psicológica mais comum diante da morte é o medo, que pode ser: 1) em relação à própria morte, surgindo o medo do sofrimento e da indignidade pessoal e, ainda, o sentimento de impotência por não poder ser feito nada se é um outro que morre; 2) do momento do pós-morte, que seria o medo do julgamento, do castigo divino e da rejeição e, em relação à morte do outro, emerge o medo da retaliação e da perda da relação; e, 3) da extinção, em que o desconhecido ameaça, surgem os medos do não ser e o medo da própria extinção e, no que diz respeito à morte do outro, a extinção desperta a vulnerabilidade proveniente da sensação de abandono (Kovács, 1992).

O que nos é mais temido na morte depende sempre do momento de vida em que nos encontramos, como por exemplo, situações externas a nós mesmos, no caso, 
uma guerra, a violência, ou conflitos que possamos estar vivenciando e, até mesmo a perda de um ente querido (Kovács, 1992).

Kubler-Ross (1996) explica que o medo da morte tem suas raízes na infância. As crianças muitas vezes podem desejar que um dos pais morra porque não conseguiram satisfazer seus desejos, mas, tendem a ver essa perda como algo reversível. Porém, à medida que crescemos percebemos que nossa onipotência não é tão grandiosa assim. O medo de que possamos ter contribuído para a morte de um de nossos pais desaparece, e com ele a culpa também. Entretanto, o medo da morte permanece subjacente e pode ser despertado ao entrarmos em um hospital, seja na posição de doente ou de acompanhante dele.

Kovács (1992) afirma que durante o processo evolutivo ocorrem várias mortes, porém, cada um de nós tem a sua própria representação do que seja a morte, que pode significar desde uma perda até um descanso e, essas formas de representação influenciam nossa forma de viver.

A presença da morte no desenvolvimento humano inicia-se desde os primeiros contatos da criança com sua mãe. As ausências da mãe são vividas como mortes pela criança, que se percebe só e desamparada. Marca que deixa a representação da morte como ausência, perda, separação e a conseqüente vivência da aniquilação e do desamparo. Por outro lado, a morte pode também representar acolhimento e conforto, frutos de uma relação maternal acolhedora e receptiva (Kovács, 1992).

Com o correr do desenvolvimento afetivo e emocional, a criança é posta a experienciar mortes concretas, que despertam nela a tentativa de compreensão. Essas mortes podem acontecer com um bicho de estimação, com um ente querido, com os amigos, dentre outros. São perdas que apresentam à criança o caráter de repentinidade, violência e acaso, fazendo com que a criança se proteja crendo que a morte é um acontecimento que só ocorre com os outros (Kovács, 1992).

A passagem do ser criança para ser adolescente requer que conhecimentos sejam adquiridos, que um corpo de mulher ou de homem seja assumido. Para tanto, há que se perder a capacidade infantil do “faz de conta”, a ordem agora é ousar e a morte não tem seu espaço porque representa derrota, fracasso, que para um 
adolescente são inadmissíveis, pelo fato dele, enquanto herói, não conceber sua própria derrota (Kovács, 1992).

O não espaço da morte no mundo adolescente apresenta algo de contraditório porque é justamente na adolescência que perdas inevitáveis ocorrem. O movimento de ousar, que é inerente à adolescência pode conter a morte do outro quanto a própria também, que podem ser mortes concretas como a perda de amigos e colegas, como podem ser as perdas próprias da adolescência, como a perda do corpo de criança e a perda do pensamento da irreversibilidade da morte (Kovács, 1992).

A vivência das mortes concretas para um adolescente não o imiscui de ser atravessado pelo desejo da imortalidade. Essas perdas, quando acontecem, são atribuídas a uma imperícia, que não será cometida por ele, assim, sua vida não será suprimida (Kovács, 1992).

Não há como definir exatamente o momento em que deixamos de ser adolescentes e nos tornamos adultos. Os indícios dessa mudança parecem estar presentes no surgimento da responsabilidade pelos outros e na colaboração com nosso próprio desenvolvimento. Além disso, tendemos a reavaliar nosso devir até aqui, por isso, ocorre em nós uma significativa mudança interna, que nos possibilita entender a morte como algo que pode acontecer conosco e não só com os outros. Assim, admitir a possibilidade da própria finitude abre espaço para que a vida seja re-significada e definida a partir da possibilidade da morte, que apresenta limites a serem conhecidos e admitidos (Kovács, 1992).

A imortalidade sempre foi a preocupação central do homem e o alicerce de sua angústia existencial. Somos fruto de uma socialização que nos coloca desde muito cedo a busca pelo sucesso, o fascínio pelo poder e a negação da dor, o que estrutura nossa auto-imagem e nosso ego. Mas, essa estruturação nos aprisiona em nosso próprio ego tornando-nos falsamente felizes, levando-nos a aceitar apenas o que é concreto e o infinito, porque nosso eu agora teme que a finitude aconteça e traga dor. Assim, é um processo de socialização que implica na negação da morte e conseqüentemente da espiritualidade, pelo fato do aceitável ser apenas aquilo que é palpável (Pierre, 1998).

Não existe em nós a crença em nossa própria finitude, buscamos sempre o belo e não somos capazes de viver com a morte sempre em nós. A solução para 
suportarmos esse impossível está na utilização de nossos mecanismos de defesa, como a negação, a repressão, a intelectualização e o deslocamento, que nos oferecem proteção do medo da morte, mas, podem também nos cercear até mesmo do viver (Kovács, 1992).

De acordo com Santos (1993) a impossibilidade de aceitação da morte por parte dos homens pode explicar a busca incessante de maneiras para dominá-la.

O medo da morte, como pôde ser percebido, é inerente ao desenvolvimento de todos os seres humanos, esse é o seu lado vital e isso justifica sua presença em alguns momentos de nossa vida. Ele mostra o instinto de autoconservação, que protege a vida e nos possibilita superar nossos instintos destrutivos. Mas, esse mesmo medo pode ser tão potente e restritivo a ponto de fazer com que deixemos a vida para não morrer. Todos nós somos colocados a viver essa contradição cabendo a cada um de nós enfrentá-la, o que dependerá de nossa história de vida, de nossa personalidade e de nosso esforço (Kovács,1992).

O despertar do medo da morte constatado em algumas das mulheres entrevistadas concorda com os achados que a literatura apresenta em relação às possíveis causas para o medo da morte, isto é, são mulheres adultas, que conseqüentemente foram crianças um dia e podem ter permanecido com o medo da morte latente, são também sujeitos submetidos à ordem social, que é capaz de instituir o horror da morte através da negação da finitude e, enfim são pessoas que tiveram que entrar em um ambiente hospitalar, que é propício para o despertar do medo da morte.

O contexto hospitalar, portanto, contribuiu na produção da representação do medo da morte, o que aponta para o fato de que o hospital possa estar significando ainda um ambiente reservado para as pessoas morrerem (Foucault, 1979).

A admissão hospitalar a que as participantes deste estudo tiveram que enfrentar, ainda colocou algumas delas diante do conflito de que para alcançar a cura era necessário se submeter à cirurgia.

Representar a admissão hospitalar necessária para a realização da cirurgia por câncer de mama enquanto cura mostra a alteridade no discurso dessas mulheres, no sentido de que algo fora delas será capaz de curá-las. 
Etimologicamente a palavra cura significa cuidado (Minayo, 1994; Boff, 1999). Sendo assim, o termo cura, de acordo com seu significado etimológico é capaz de dar sentido às representações sociais da admissão hospitalar enquanto resolução do câncer de mama e cuidado dele também.

A identificação do câncer de mama no mundo está intimamente ligada à busca de sua cura. No Egito, entre 1587 e 1328 A.C., já havia registros sobre o câncer de mama. O entendimento, nessa época, era de que não havia cura para o câncer de mama quando um seio, ao ser tocado, estava frio e repleto de tumores. Era um período em que se utilizavam remédios caseiros para o tratamento do câncer, havia o uso de miolos de vaca e excremento de vespa dentre outros (Yalom, 1998).

Mais tarde, no século XIII, é que médicos como Guglielmo concluíram que o câncer de mama era passível de cura apenas através de cirurgia, na qual era retirada toda a parte afetada seguida por uma cauterização e aplicação de substâncias calmantes. Entretanto, não havia anestesia e muitas mulheres morriam por infecções causadas pelas cirurgias sem esterilização, panorama que começou a mudar apenas na segunda metade do século XIX, quando a anestesia e os princípios antissépticos foram adotados (Yalom, 1998).

O combate ao câncer de mama segue atualmente quatro métodos principais, que são: a cirurgia, a quimioterapia e/ou radioterapia e as terapias hormonais, no caso do câncer de mama ter sido diagnosticado como sendo hormônio dependente (Yalom, 1998).

A busca da cura para o câncer de mama, até este momento relatada, está ligada exclusivamente à medicina. Entretanto, de acordo com Boff (1999), as tradições terapêuticas sempre perceberam a cura como um processo global, no qual o doente tem de ser tratado em sua totalidade e não apenas em relação a uma parte do seu corpo. Essas formas de ajuda geralmente acontecem em grupos compostos por vários profissionais, que buscam levar o usuário a ter uma qualidade de vida melhor. Um exemplo de equipe que trabalha nesse sentido é a que compõe o REMA (Núcleo de Ensino, Pesquisa e Assistência na Reabilitação de Mastectomizadas), que é vinculado ao Departamento de Enfermagem Materno-Infantil e Saúde Pública da Escola de Enfermagem de Ribeirão Preto da Universidade de São Paulo (USP). 
A cura não é algo presente apenas em serviços oferecidos por profissionais da área da saúde. Muitos cultos religiosos, no Brasil, também oferecem a cura (Rabelo, 1994) por intermédio de seus rituais, que parecem inserir o doente num contexto de experiência diferente do anterior à doença.

Na medicina popular a cura pode ser compreendida a partir do modo como o sujeito doente é tratado. Nesse tratamento não há a responsabilização do doente pela sua condição, mas, há a implicação subjetiva com sua condição. A assistência é prestada de forma globalizada e há uma proximidade muito estreita entre o doente e o curandeiro (Laplantine, 1991). Diferentemente do modo como a cura é buscada no modelo médico vigente. Nele, o doente pode chegar a ser culpado pela sua condição; não há a implicação subjetiva com sua condição; o cuidado prestado ocorre, muitas vezes, de forma fragmentada e, na maioria das vezes também não há uma proximidade entre o médico e aquele que está sob seus cuidados.

A cura era um dos pensamentos presentes também na literatura do século XX. Ela era concebida como proveniente da natureza (Laplantine, 1991).

A analogia da cura com a natureza consistia no respeito ao tempo que cada indivíduo teria para readquirir sua saúde. Para que essa fosse atingida haveria o mínimo de intervenções mecânicas dos homens, ou seja, o próprio indivíduo seria capaz de se curar.

Minayo (1994) afirma que uma pessoa movida pela cura está diante de situações "que considera situações-limite, concretizadas em doenças graves, insegurança material e espiritual e desordens morais”(p. 57).

O cenário apresentado por Minayo (1994) parece simbolizar o momento que as mulheres entrevistadas que significaram a admissão hospitalar enquanto cura tiveram que enfrentar. A internação dessas mulheres foi necessária devido a uma doença grave, ou seja, decorrente do câncer de mama. Isso significa que essas participantes foram colocadas diante da concretização de uma situação-limite, que implica no despertar da cura.

O significado das representações sociais verbalizadas pelas entrevistadas em relação à admissão hospitalar necessária para a realização da cirurgia por câncer de mama, remete à busca da cura, que sempre parece ter sido uma preocupação fundamental dos profissionais que lidam com o câncer. Além disso, a própria 
presença de uma doença grave, como o câncer, parece mover os sujeitos que a possuem a buscarem sua cura.

A cirurgia por câncer de mama no momento da admissão hospitalar necessária para sua realização também foi representada como um cuidado enquanto estratégia de retorno à saúde.

Entendemos que a contextualização do movimento da medicina holística possa nos dar subsídios para compreender essa categoria.

A medicina ocidental é marcada desde a época clássica por dois opostos. O primeiro deles, o alopático, postula que o médico deve ser um profissional voltado contra a doença, que para tanto deve utilizar os recursos disponíveis, que podem ser as cirurgias, e os remédios, dentre outros. Diferentemente da segunda visão, a "naturopática”, que posiciona o médico como um colaborador das potencialidades de cura do corpo daquele que é cuidado, fortalecendo-as e apoiando-as, dessa maneira, estará ajudando aquele que está sob seus cuidados a tornar-se saudável (LeShan, 1992).

O Movimento Popular de Saúde (MPS) representava a ala “naturopática”, era composto por médicos que utilizavam remédios produzidos a partir de plantas e ervas, criticavam os médicos tradicionais, por entenderem que realizavam tratamentos "bárbaros”, eram arrogantes e cobravam honorários injustos. O objetivo final do MPS era fazer com que cada homem se tornasse seu próprio médico (LeShan, 1992).

No outro oposto estavam os médicos que acreditavam apenas em procedimentos realizados ativamente, porque não partiam do pressuposto de que o corpo pudesse se curar naturalmente (Leshan, 1992).

Na realidade nenhuma das escolas de medicina obteve sucesso na cura das pessoas. O que a história mostra é que os anos de 1849 representam um marco. Até essa data a medicina "naturopática" parecia estar prestes a estabelecer sua hegemonia, mas, foi nessa época também que a visão alopática da medicina ganhou corpo, isso aconteceu devido a dois avanços importantíssimos: a teoria dos micróbios e a união da medicina à química. A partir disso originou-se a cirurgia anti-séptica e indolor, além do controle de doenças fatais como o cólera e a febre amarela, dentre outras. Por isso, a medicina tradicional ganhou autoridade e fama (LeShan, 1992). 
Entretanto, a cura aparece novamente como medida da eficácia da medicina. Autores como Fux (2001) afirmam que a prática médica tinha como objetivos vencer a doença e a morte e esses objetivos eram buscados incessantemente. Dessa maneira, chegou-se ao consenso de que a medicina tradicional era bastante eficaz no tratamento de doenças contagiosas fatais, mas, não era capaz de tratar de forma satisfatória as doenças degenerativas, como o câncer, e nem mesmo problemas cardíacos. A partir desse conflito surge a teoria da medicina holística, com o objetivo de unir as duas escolas de medicina já conhecidas, de forma a apreender o melhor de cada uma formando um todo mais forte (Leshan, 1992).

A medicina holística é composta por quatro axiomas organizados formando um todo coeso. O primeiro deles considera que todos os seres humanos possuem os níveis físico, psicológico e espiritual tendo o mesmo grau de relevância, assim a saúde é alcançada quando esses três níveis são tratados. O segundo axioma leva em conta que cada pessoa é única, o que nega a eficácia de uma abordagem padronizada. O terceiro ponto relevante é tornar aquele que é cuidado como parte das decisões da equipe, se houver aceitação do mesmo. E o quarto e último axioma postula que se deve partir sempre do pressuposto de que a pessoa que é tratada possui habilidades de auto-cura (Leshan, 1992).

Um elemento importante considerado por um dos axiomas que compõem a medicina holística refere-se à participação daquele que é cuidado em seu próprio tratamento. Essa possibilidade foi oferecida à quinta participante, como mostra o quinto mapa de associação de idéias, na temática participação na decisão e/ou desconhecimento da cirurgia.

A abertura à participação da quinta participante para a escolha em se submeter à cirurgia por câncer de mama foi compreendida por ela de forma positiva, ou seja, essa entrevistada desejava ser tratada de uma forma holística e ela teve a possibilidade de escolher entrar ou não no hospital nesse dia, e talvez ela tenha sido admitida esperando ser respeitada da mesma forma que foi respeitada no momento de escolher sobre sua cirurgia.

A possibilidade da escolha despertou na presente entrevistada segurança, que também foi fornecida a ela por sua rede de suporte continente, que motivaram-na a chegar sozinha ao hospital sentindo-se calma e tranqüila. 
O reconhecimento e entendimento da importância da cirurgia para a quinta entrevistada não apagaram nela emoções como o medo e o reviver do trauma de cirurgia, como pode ser verificado no mapa de associação de idéias cinco. Além disso, o falar sobre o câncer, para essa participante, ocorreu por meio do seu corpo e não através da palavra propriamente dita.

Assim, a admissão hospitalar necessária para a realização da cirurgia por câncer de mama fez com que essa participante tivesse que conviver com dois opostos: a segurança quanto ao cuidado que receberia, mas, as incertezas de ter um câncer e ter que ser operada por esse motivo.

A representação social dia normal foi ainda uma das representações sociais relacionadas à cirurgia por câncer de mama no momento da admissão hospitalar necessária para sua realização.

A décima participante deste estudo representou sua chegada ao hospital necessária para a realização da cirurgia por câncer de mama como um dia normal. Inicialmente, ao ser admitida no hospital, a presente entrevistada realmente parecia enfrentar este momento com serenidade e tranqüilidade, o que podia ser um indício de que a admissão hospitalar representada como um dia normal era uma representação condizente com seus pensamentos e sentimentos.

Porém, a serenidade e a tranqüilidade dessa participante eram apenas aparentes. Uma de suas filhas havia retirado uma das mamas a poucos dias e agora era ela que estava na mesma posição da filha, dessa forma era realmente muito difícil para ela enfrentar sua chegada ao hospital de forma diferente.

O contexto no qual a presente entrevistada encontrava-se no momento desse estudo foi, portanto, de suma importância na produção da representação social dia normal. Essa participante pode ter representado sua admissão dessa forma pelo fato de ter vivenciado previamente com sua filha o que hoje, no dia de sua internação, ela poderia experienciar, ou seja, o impacto que a admissão poderia lhe causar já havia ocorrido. 


\subsection{ESTRATÉGIAS DE ENFRENTAMENTO}

O enfrentamento é um termo que possui várias definições, que podem ser agrupadas de acordo com Gimenez (1997), como aquilo que demanda do sujeito respostas a situações estressantes, que podem ser tanto de cunho externo, que são as vivenciadas socialmente, quanto de cunho interno, que estão circunscritas à vida emocional dos sujeitos.

Entendemos a admissão hospitalar necessária para a realização da cirurgia por câncer de mama como um momento estressante na vida das mulheres que tem de vivenciá-la. Esse momento despertou nas participantes deste estudo ações e comportamentos de enfrentamento, como a escolha de Deus e dos médicos, a busca interna e outras estratégias de enfrentamento.

\subsubsection{Deus}

A escolha de Deus como estratégia de enfrentamento foi verbalizada pelas entrevistadas um, dois, cinco, seis, sete, oito nove e dez. Essas entrevistadas, demonstraram ainda tranqüilidade, submissão, verborragia e necessidade de controle.

A presença de Deus no momento da admissão hospitalar das participantes deste estudo, portanto, foi importante para fornecer-lhes tranqüilidade, mas, também 
esteve relacionada a comportamentos de submissão, à verborragia e à necessidade de controle.

O experienciar Deus é a essência da fé individual de cada um dos seres humanos. Essa vivência, entretanto, é realmente significativa se aflorar do que de mais profundo experiencia-se com os outros no mundo e é desse processo que se pode sentir e viver a transparência de Deus em nossas vidas. Para que essa transparência possa ser alcançada, Boff (2002), defende a hipótese de que há que se percorrer três fases.

A primeira fase caracteriza-se pela denominação que damos a Deus, que pode ser de Senhor, de Pai, dentre outros. Nessa fase não há ainda a consciência de que essas denominações são apenas representações do que não pode ser representado. Deus aqui é aquilo que fazemos dele, movimento que realizamos com o intuito de encher nossa vida de sentido.

A segunda fase do aparecimento de Deus na linguagem humana pode ser percebida quando há a percepção de que as imagens de Deus não são suficientes para nos completar tanto quanto na primeira fase. Deus passa a ser um símbolo que significa apenas transcendência porque passamos a fazer o movimento de questionar todas as nossas representações, isto é, Deus não está mais identificado a aquilo que dizemos dele.

Na terceira fase nos reconciliamos com as imagens de Deus. Primeiro as afirmamos, depois as negamos e, finalmente nos reconciliamos com elas e há a compreensão de que nossa comunicação com Deus só pode ocorrer por meio das imagens, mas, estamos libertos delas e, por isso, podemos iniciar suas vivências.

Boff (2002) afirma que essas fases são momentos nos quais temos uma experiência total de Deus. Nunca finalizamos esses movimentos porque Deus será sempre mistério em nossas vidas e, o saber suportar viver esse mistério é que nos possibilita viver a transparência dele em tudo e celebrá-lo em cada situação cotidiana.

A experiência de Deus, portanto, hoje, implica em uma postura crítica em relação às nossas representações sobre seu mistério, o que nos possibilita experimentá-lo, ou seja, senti-lo em nosso coração. 
Concordamos com Bittencourt \& Cadete (2002) que o apego a Deus, na mulher que se submeterá à cirurgia por câncer de mama, significa um auxílio de suma importância para o enfrentamento do processo cirúrgico. As autoras ainda afirmam que talvez a crença em algo superior seja intensificada pela presença do câncer de mama e, que essas mulheres parecem buscar Deus pela necessidade de se sentirem protegidas, recompensadas e estimuladas na continuidade da vida (Silva \& Mamede, 1998).

\subsubsection{Médicos}

Os médicos também foram escolhidos enquanto estratégia de enfrentamento pelas entrevistadas um, seis, e oito, estando relacionada à tranqüilidade e à verborragia.

A relação da presença do médico com a tranqüilidade e a verborragia se assemelha também com a presença de Deus nas mulheres entrevistadas.

O entendimento da escolha da figura do médico como estratégia de enfrentamento parece-nos importante ser resgatado a partir da história moderna da medicina.

A medicina moderna possui como marco de seu nascimento o final do século XVIII e como ponto fundamental de análise, a clínica. (Foucault, 1987).

A clínica apresenta-se como a possibilidade da medicina não desaparecer, é ela que fornece à medicina seu movimento histórico (Foucault, 1987).

No século XVIII, a medicina se submeteu pelo menos parcialmente ao modelo naturalista, que preconizava: "ver, isolar traços, reconhecer os que são idênticos e os que são diferentes, reagrupá-los, classificá-los por espécies e famílias” (Foucault, 1987, p. 100).

A tradição médica do século XVIII entendia a doença por meio de seus sintomas e signos. O sintoma significa a forma como a doença se apresenta e, o signo, "anuncia: prognostica o que vai se passar; faz a anamnese do que se passou; diagnostica o que ocorre atualmente” (Foucault, 1987, p. 102). Portanto, a formação 
do método clínico, nessa época, estava ligado ao que emergia ao olhar do médico no âmbito dos signos e dos sintomas.

A medicina no século XVIII também apresentou como uma de suas características a questão da incerteza, combatida por meio do saber probabilístico, que significava fazer "de cada elemento percebido um acontecimento registrado $e$ da evolução incerta em que ele se encontra colocado uma série aleatória” (Foucault, 1987, p. 110). Esse saber probabilístico possibilitou à medicina a percepção dos acontecimentos a partir de um domínio aberto e não mais individualizante e, inclusive, a possibilidade da abertura da clínica ao visível foi fornecida por esse tipo de saber aliado ao modelo gramatical, baseado na análise dos signos.

Uma nova visão da clínica pode ser situada no século XIX. Nesse período o olhar continua a ser fundamental, mas, além de constatar, descobre também. O hospital passa a ser uma escola, e o ensino da clínica adquire a essência de ser uma prática comparada à arte, fundada na observação do doente em seu leito (Foucault, 1987). E essa vivência é que seria a via para se atingir a cura.

Atualmente a medicina representa a moral e a religião. A primeira foi instituída através da prevenção médica, que trouxe como conseqüências: as restrições que, muitas vezes, são impostas a alguns doentes por seus médicos e, a vigilância constante de pessoas próximas a esses doentes, que sempre estão prontos a culparlhes e a lembrar-lhes de sua condição. E a conotação religiosa presente na medicina pode ser percebida por “medir a ignorância, recompensar a obediência, punir a transgressão, lutar contra o charlatanismo e intervir em domínios cada vez mais extensos da vida cotidiana de cada um de nós” (Laplantine, 1991, p. 237-238).

Devido à atualmente a medicina ter como um dos seus princípios norteadores a religião, e pelo fato também de nos discursos das mulheres entrevistadas a questão religiosa ter emergido de forma significativa como estratégia de enfrentamento da admissão hospitalar necessária para a realização da cirurgia por câncer de mama, por meio das palavras: Deus, crenças, fé e oração, que são termos pertinentes ao vocabulário religioso, entendemos ser necessária a compreensão da medicina não apenas através da via histórica como foi relatada até este momento, mas também, compreendendo-a por meio da religião. 
As religiões possuem como essência, "o esforço para pensar a realidade toda a partir da exigência de que a vida faça sentido” (Alves, 2002, p. 9). E é na ausência que todos nós mais nos remetemos a elas.

O tocar na ausência, na nossa concepção, institui a religião, que é "teia de símbolos, rede de desejos, confissão da espera, horizonte dos horizontes...” (Alves, 2002, p. 24).

A admissão hospitalar representou momentos de ausências para as participantes desta pesquisa. Essas ausências estiveram relacionadas à perda da mama ou de parte dela, ausência de seus entes queridos e de seus pertences pessoais.

A internação hospitalar também leva o indivíduo à despersonalização e é geradora de sofrimento e apreensão, pois leva o hospitalizado a se separar de tudo o que lhe é familiar. Essa separação leva esse sujeito a ter que vivenciar situações como o isolamento, a rejeição e o abandono (Moraes, 1994).

A hospitalização, segundo Angerami (2001), faz com que o sujeito sofra um processo de despersonalização, sua patologia e o número de seu leito assumem uma importância muito maior do que seu próprio nome e seu próprio ser.

A perda da identidade que ocorre dentro da instituição hospitalar também é causada pelos diagnósticos cada vez mais específicos, o que deixa à mostra apenas o sintoma (Angerami, 2001), conseqüentemente há o apagamento do sujeito.

O movimento das mulheres frente a todas essas ausências foi de se remeterem ao símbolo do médico, figura que apareceu como representante da cura, assim como nos séculos XVIII e XIX e como possibilidade de tamponar as ausências que a hospitalização representa, o que significa ainda uma escolha religiosa dessas mulheres. Sendo assim, as participantes que escolheram o médico como uma das formas de enfrentar o momento da admissão hospitalar necessária para a realização da cirurgia por câncer de mama, a fizeram com o intuito de que a vida pudesse ter possibilidade de sentido e, para que a chegada ao hospital não fosse um momento de ter que lidar com mais faltas ainda do que esse momento representa por si só na vida de uma pessoa.

Os médicos, assim como Deus, ao serem utilizados pelas mulheres que se submeteriam à cirurgia por câncer de mama, enquanto estratégia de enfrentamento, possibilitaram-nas ainda tranqüilidade para entrarem no hospital. Entretanto, eles não 
foram suficientes, pois essas mulheres tiveram que se utilizar da verborragia que foi mais um recurso empregado por elas na tentativa de preencher o vazio imposto pela admissão hospitalar, bem como para que pudessem se defender dessas ausências.

Os médicos não foram presentes apenas enquanto estratégia de enfrentamento, eles emergiram ainda no contexto de participação das mulheres na decisão de realização da cirurgia. As mulheres com câncer de mama parecem mostrar desejo em participar das decisões de seus tratamentos (Keating et al, 2002). Porém, os médicos não parecem estar suficientemente preparados para lidarem com o desejo de participação dessas mulheres (Bruera et al, 2002; Brown et al, 2002).

Arantes (2002) ressalta que para uma mulher com câncer de mama não é tarefa fácil participar da escolha de seu tratamento porque ele implica no entendimento da história do tumor, o que nem sempre é uma questão simples. Nesse sentido, a cirurgia é algo que uma mulher com câncer de mama parece desejar, porém, é um procedimento de entendimento complexo para uma pessoa que não pertence à área médica. Além disso, os médicos, que são os profissionais responsáveis por comunicar a necessidade da cirurgia parecem não estar preparados para compartilhá-la com aqueles que estão sob seus cuidados de forma participativa, como foi constatado na quase totalidade do grupo de mulheres participantes deste estudo.

A cirurgia como componente do tratamento por câncer de mama é percebido por mulheres que a ela se submetem como um benefício de curto prazo para a saúde, sugerindo que é uma escolha que ajuda na recuperação dessas mulheres, entretanto, não é um procedimento que fornece benefícios de longo prazo (Polsky et al, 2002).

A participação na decisão de realização da cirurgia apresenta-se assim como um processo complexo que parece ter suas raízes ainda na formação de um futuro médico, profissional que parece não ser instrumentalizado suficientemente para lidar com o conflito estabelecido entre a necessidade fisiológica da cirurgia, apresentada pelos exames normalmente realizados e o entendimento de que a pessoa que apresenta essa necessidade física é um ser de desejo e vontade que necessita ser escutado quanto à aceitação ou não de realização desse procedimento. 


\subsubsection{A busca interna}

A busca interna utilizada enquanto estratégia de enfrentamento pela terceira, quarta e quinta entrevistadas, relacionou-se à tranqüilidade, à busca de informação, à necessidade de controle e submissão.

A busca pelo suporte interno parece evidenciar a implicação dessas mulheres com suas respectivas internações. Essa inter-relação parece estar presente apenas quando é geradora de tranqüilidade e busca de informação, ao contrário das estratégias necessidade de controle e submissão, contudo, o modo como as entrevistadas que utilizaram as últimas estratégias citadas, se colocaram no decorrer de suas entrevistas como mostra as análises de seus mapas associativos e gráficos, corroboram para o entendimento de que elas se implicaram com suas internações também.

\subsubsection{Outras estratégias de enfrentamento utilizadas}

As entrevistadas quatro, cinco e sete relataram no decorrer de suas entrevistas que: a família; o namorado; outros que passaram pela mesma experiência e, a convivência com pessoas brincalhonas capazes de passar energia boa, eram algumas de suas estratégias para enfrentar o momento da chegada ao hospital.

Essas estratégias foram de fundamental importância na complementação do conjunto das estratégias utilizadas por essas participantes durante suas internações, são estratégias de fácil acesso mesmo após o término da internação, ou seja, são eficazes para o suporte dessas mulheres em todos os momentos pelos quais elas ainda terão que percorrer.

O tratamento utilizado para o câncer de mama é composto por várias etapas, não ficando circunscrito apenas à cirurgia, por isso, na maioria dos casos é um tratamento longo e desgastante, requer da pessoa que a ele adere uma mudança de 
rotina de vida, pelo menos enquanto o tratamento impõe idas diárias ao hospital, no caso por exemplo da realização da radioterapia.

A convivência com a rotina hospitalar é desgastante e desafiadora porque desperta questionamentos existenciais, como da própria continuidade da vida. Nesse sentido, o contexto no qual essas pessoas estão inseridas são de suma importância para que não se sintam mais doentes e deprimidas, com a sensação de que tudo o que lhes rodeia é composto por doença, sofrimento e morte.

As pessoas doentes de câncer necessitam de redes de solidariedade muito bem estabelecidas e capazes de lhes impulsionar na continuidade de seus objetivos. Essas redes podem ser criadas não necessariamente por amigos ou familiares, mas, também por grupos que se propõem a ajudar pessoas que receberam o diagnóstico de câncer um dia. Esse encontro entre iguais, mas, diferentes em relação às etapas do tratamento e tempo de diagnóstico é de suma importância para que essas pessoas possam retomar suas vidas como eram anteriormente ao diagnóstico.

\subsubsection{O contexto como facilitador das estratégias de enfrentamento}

O contexto de nosso estudo foi o hospital, mais especificamente ainda uma enfermaria de ginecologia e obstetrícia de um dos hospitais-escola de Ribeirão Preto, SP.

Dentre todos os profissionais que prestaram cuidado às participantes deste estudo, houve a observação da realização do procedimento de admissão hospitalar desempenhado pelos principais profissionais que estiveram envolvidos nele, por entendermos que essas observações nos forneceriam mais dados para compreendermos melhor o que é para uma mulher entrar em um hospital para se submeter à cirurgia por câncer de mama.

As observações realizadas evidenciaram que: 1) os principais responsáveis pelas admissões foram enfermeiras; 2) todas as enfermeiras tentaram estabelecer vínculos positivos com as mulheres que estavam sendo internadas, no momento do chamamento; 3) $80 \%$ das enfermeiras não se apresentaram às mulheres que se 
submeteriam à cirurgia por câncer de mama; 4) 90\% das enfermeiras, na maior parte do tempo em que estiveram admitindo as usuárias do serviço, não as trataram por seus nomes próprios, preferiram o termo senhora; 5) 100\% das enfermeiras mostraram-se preocupadas em assegurar que cada mulher admitida teria um espaço físico para si; 6) 70\% das enfermeiras foram capazes de abrir espaço e escutar as mulheres que ali chegavam; 7) 80\% das enfermeiras receberam as usuárias na posição ereta; 8) 60\% das admissões hospitalares contaram com a presença de uma enfermeira e de uma auxiliar de enfermagem.

As enfermeiras foram responsáveis: 1) pelo recebimento das mulheres que chegavam para serem admitidas para a realização da cirurgia por câncer de mama; 2) pela apresentação dos pertences que essas mulheres poderiam utilizar durante a estada no hospital; 3) através de um protocolo que a presente enfermaria possui para a admissão e alta de suas usuárias, era realizada uma entrevista e o histórico de enfermagem.

Às auxiliares de enfermagem couberam a verificação dos sinais vitais, do peso e altura das mulheres que participaram desta pesquisa e ainda, a coleta de sangue, que é rotina do hospital.

As observações das dez admissões hospitalares que fizeram parte de nossa amostra mostraram que todas as enfermeiras observadas tentaram estabelecer um vínculo positivo com as mulheres que chamaram para serem levadas aos quartos onde permaneceriam a maior parte do tempo dentro do hospital. Foram chamamentos realizados face a face e com a utilização dos nomes próprios das mulheres que seriam admitidas.

Apesar de não ter havido o apagamento das participantes no momento do chamamento, esse ocorreu logo em seguida. Apenas as enfermeiras que realizaram a segunda e terceira admissões observadas apresentaram-se às mulheres que ali chegaram.

Segundo Goffman (1992), o movimento de apagamento do sujeito promovido pela instituição hospitalar leva à fragmentação do cuidado prestado, além de ser uma forma de mutilação do eu. 
No caminho até o quarto e dentro dele, somente a enfermeira responsável pela admissão da terceira participante, tratou-a pelo seu nome próprio. As outras enfermeiras preferiram o termo senhora.

Todas as enfermeiras preocuparam-se em assegurar às mulheres que estavam admitindo que ali havia um espaço físico para elas, demonstrado através dos pertences que poderiam ser utilizados por elas durante o período de hospitalização, o que pode ter despertado nas mulheres o sentimento de pertença ao grupo e ao ambiente físico.

O asseguramento do espaço da escuta, entendida como a capacidade de abertura para o falar do outro e para a compreensão do que ele diz, foi outro aspecto relevante observado nas enfermeiras, ele esteve presente em $70 \%$ delas, o que pode ter auxiliado as mulheres que ali chegaram a se reorganizarem após o primeiro impacto da chegada ao hospital. Somente as responsáveis pelas admissões da primeira, quarta e quinta entrevistadas não o asseguraram, o que expôs estas últimas participantes a um cuidado fragmentado, porque: 1) os profissionais não se apresentaram a elas; 2) elas não foram tratadas pelos seus nomes próprios; 3) não foram escutadas e, 4) foram admitidas pelas enfermeiras e pelas auxiliares de enfermagem de forma separada.

No período compreendido entre a chegada ao quarto e a saída da enfermeira, todas nós permanecemos de pé, exceto na segunda e oitava admissões. Apesar de em todos os quartos ter havido estrutura física para termos permanecido assentadas.

As mulheres que participaram deste estudo receberam cuidados de vários profissionais, entretanto, esses cuidados foram prestados, em alguns momentos, de forma fragmentada.

Com exceção da terceira e sexta participantes, as admissões foram realizadas pelas enfermeiras e pelas auxiliares de enfermagem de forma desvinculada, tendo sido delegado às auxiliares a verificação dos sinais vitais, peso, altura e a coleta de sangue de rotina do hospital.

As admissões hospitalares observadas, portanto,caracterizaram-se em grande parte: 1) pelo recebimento da pessoa que permaneceria hospitalizada por um período; 2) pela apresentação dos pertences que ela poderia utilizar durante sua estada no 
hospital; 3) a realização de uma entrevista; 4) a verificação dos sinais vitais; e, 5) o histórico de enfermagem.

Entretanto, nossa compreensão do procedimento de admissão hospitalar ultrapassa o que foi colocado anteriormente.

Entendemos que a admissão de uma pessoa em um hospital deva ser realizada levando em conta a estranheza do ambiente hospitalar, onde os profissionais são desconhecidos, bem como a linguagem que utilizam. Compreendemos ainda que este é um momento no qual a pessoa formará suas primeiras representações em relação a este ambiente. Essas representações influenciarão também nas escolhas das estratégias de enfrentamento que serão utilizadas. E mais, os profissionais envolvidos nesse momento têm de estar atentos às demandas que as pessoas que ali chegam apresentam, porque dessa maneira conseguirão prestar um cuidado em que corpo, mente e espírito possam estar integrados.

A entrada no hospital significa, assim, o encontro com o desconhecido, o que pode despertar medo, solidão e insegurança (Beland \& Passos, 1978).

Nas dez mulheres que participaram de nosso estudo, a admissão hospitalar necessária para a realização da cirurgia por câncer da mama, despertou aborrecimento, tristeza, medo, paz, esperança e preocupação.

São sentimentos que corroboram com nosso entendimento do que vem a ser a admissão hospitalar, ou seja, eles evidenciam que as mulheres que ali chegaram tinham necessidades que iam além das físicas. Por isso, é importante e necessária a discussão do papel dos profissionais responsáveis pelas admissões hospitalares realizadas.

Por ser a admissão hospitalar um momento no qual o sujeito é colocado diante de várias ausências, entende-se que, por isso, o papel dos profissionais que realizam tal procedimento é muito importante. Entrar e estar em um hospital para uma pessoa com câncer implica na necessidade de uma equipe multiprofissional, a fim de que possibilite a essa pessoa o enfrentamento da realidade (Garcia, 1999). Porém, esse trabalho deve ser desenvolvido de forma integrada, de forma que aquele que necessita de cuidados não seja tratado “por partes”.

Em nossa pesquisa, as enfermeiras e auxiliares de enfermagem que realizaram as admissões hospitalares estudadas aproximaram-se, mas, também se distanciaram 
de um cuidado capaz de ter oferecido o suporte adequado para que as mulheres admitidas para se submeterem à cirurgia por câncer de mama pudessem ter enfrentado esse momento com menos aborrecimento, tristeza, medo e preocupação.

Consideramos que os fatores que contribuíram para a realização das admissões hospitalares de forma a proporcionar suporte para as mulheres que ali chegaram foram: 1) tentativa do estabelecimento de um vínculo positivo no momento do chamamento; 2) asseguramento do espaço físico; e, 3) o espaço da escuta, presente em $70 \%$ das enfermeiras.

Porém, 90\% das enfermeiras não se fizeram conhecer por suas clientes, o que pode ter contribuído para o aumento do medo em algumas das participantes, já que ele é um sentimento que surge do desconhecido. 90\% das enfermeiras, salvo no momento do chamamento, não reconheceram também as mulheres que admitiram, porque preferiram utilizar o termo senhora e não os nomes próprios de cada uma das usuárias. 80\% das enfermeiras desempenharam seu papel de pé, apesar de sempre ter havido a possibilidade da permanência de todas assentadas. A presença da enfermeira e da auxiliar de enfermagem ocorreu em 60\% das admissões, talvez o cuidado tenha sido prestado de forma fragmentada não pelo fato da presença de ambas, mas, porque a usuária parece ter sido dividida entre o que é de domínio da enfermeira e o que se entende que seja o papel do auxiliar de enfermagem.

Corbellini \& Comiotto (2000) afirmam que a assistência prestada pelos profissionais da área da saúde tem de estar baseada na visão de mundo daquele que é assistido, porque isso leva o cliente a ter um maior contato com estratégias de enfrentamento como a religião.

Possivelmente em nosso grupo a escuta dos profissionais foi capaz de identificar algumas necessidades físicas e psicológicas das mulheres que ali chegaram, porém, não foi uma escuta capaz de identificar as estratégias de enfrentamento que cada mulher tentou utilizar, assim, a possibilidade dos profissionais de incentivar as usuárias a se utilizarem muito mais de suas estratégias de enfrentamento não ocorreu. 


\subsubsection{A relação das representações sociais com as estratégias de enfrentamento utilizadas}

Consideramos a admissão hospitalar necessária para a realização da cirurgia por câncer de mama um momento muito difícil na vida de uma mulher que precisa enfrentá-la, pelo fato de implicar em várias ausências e a convivência com o ambiente estranho e estressante do hospital.

Por ser a admissão hospitalar de uma mulher com câncer de mama um momento delicado, entendemos que ele desperta nas mulheres a ele submetidas muitas representações e conseqüentes estratégias de enfrentamento.

Apresentamos a seguir as representações sociais categorizadas das participantes deste estudo juntamente com as estratégias de enfrentamento por elas utilizadas.

Verificamos que a representação social categorizada por perda da mama esteve relacionada às estratégias de enfrentamento caracterizadas pela tranqüilidade, pelos médicos e por Deus.

A representação social categorizada como medo da morte relacionou-se às estratégias de enfrentamento submissão, Deus, verborragia, necessidade de controle, convivência com pessoas brincalhonas capazes de passar energia boa e fé em Deus.

A terceira categoria definida como capaz de dar sentido a algumas das representações verbalizadas foi a cura, relacionada às estratégias de enfrentamento tranqüilidade, busca de informação, si mesma, necessidade de controle, próprias crenças, família, namorado, médico, oração, Deus e verborragia.

O cuidado enquanto estratégia de retorno à saúde relacionou-se às estratégias de enfrentamento tranqüilidade, aos outros que passaram pela mesma experiência, à fé em Deus, à coragem, à confiança e à força de vontade.

A última categoria foi definida como dia normal e esteve relacionada às estratégias de enfrentamento tranqüilidade e Deus.

A representação social perda da mama mostrou-se muito significativa para a primeira participante, pelo fato de conceber seu seio como um símbolo de sua 
identidade feminina. Entretanto, os médicos e Deus parecem ter contribuído para que ela enfrentasse o momento da admissão hospitalar de forma mais tranqüila.

A representação social definida como medo da morte mobilizou nas participantes que assim significaram a admissão hospitalar, estratégias de enfrentamento marcadas, em sua maioria, pela alteridade, evidenciadas pela escolha de Deus. Isso parece significar que se a possibilidade da morte existe, num primeiro momento pode haver a tentativa de fuga também, o que pode explicar a escolha de Deus.

A cura foi uma outra representação associada à admissão hospitalar. Ela relacionou-se a estratégias de enfrentamento presentes tanto no mundo externo quanto no mundo interno das mulheres que assim a significaram, e essas estratégias despertaram tranqüilidade quando apenas a busca interna foi utilizada aliada às presenças de Deus, dos médicos e da oração.

A representação da admissão hospitalar como um cuidado enquanto estratégia de retorno à saúde também emergiu estando relacionada à tranqüilidade, que ainda parece ter sido resultado das estratégias de enfrentamento continentes que a quinta participante utilizou, dentre as quais ela esteve presente.

A décima participante desta pesquisa representou sua admissão hospitalar necessária para a realização da cirurgia por câncer de mama como um dia normal, que foi enfrentado com tranqüilidade e com a ajuda de Deus. Parece-nos que a representação de normalidade e a presença de Deus foram eficazes para que ela se mantivesse tranqüila ao ser internada. Contudo, entendemos que essa participante necessitou dessa aparente normalidade porque uma de suas filhas havia saído recentemente do hospital por causa de uma cirurgia por câncer de mama e ainda não estava recuperada no dia em que ela, mãe, era internada para se submeter ao mesmo procedimento.

As representações sociais e as estratégias de enfrentamento verificadas no discurso que esse grupo foi porta-voz evidenciam, portanto, que as categorias: cura, o cuidado enquanto estratégia de retorno à saúde e dia normal foram as representações que mais auxiliaram no enfrentamento da admissão hospitalar necessária para a realização da cirurgia por câncer de mama. 
Fica evidente também que as escolhas dos médicos e de Deus enquanto estratégias de enfrentamento puderam fornecer suporte para o enfrentamento da admissão hospitalar necessária para a realização da cirurgia por câncer de mama, ainda que tenham sido escolhas marcadas pela alteridade.

A busca pela compreensão do momento da admissão hospitalar necessária para a realização da cirurgia por câncer de mama nos direcionou para um universo desconhecido, mas, que nos impulsionava para sua descoberta.

O caminho para a compreensão desse fenômeno nos colocou frente a dez mulheres que tinham em comum a necessidade de realização dessa cirurgia e os profissionais que as receberam nesse momento.

Tivemos a oportunidade de perceber que a chegada dessas mulheres ao hospital, pela necessidade de realização desse procedimento cirúrgico, não tinha como ser compreendida sem entendê-la como uma rede composta por elas, pelos profissionais que as admitiram e pelas características organizacionais e simbólicas de um hospital.

Algumas dessas participantes significaram esse processo como algo capaz de curar-lhes, outras como capaz de lhes ameaçar a vida, dentre outras. Esses significados nos apontaram para o sofrimento dessas mulheres, que tinham a percepção de que estavam se internando porque possuíam algo grave, e que era uma internação que iria deixar-lhes sem uma mama ou sem uma parte dela.

O sofrimento experimentado por essas participantes também foi percebido nos profissionais que admitiram essas mulheres. Talvez, um indício desse sofrimento seja a realização de $80 \%$ das admissões na posição ereta, que é um dado que pode também ter sido construído juntamente com as impossibilidades institucionais, que colocam esses profissionais para produzirem sempre mais no menor tempo possível.

Possivelmente pela admissão hospitalar necessária para a realização da cirurgia por câncer de mama ter sido significada em grande medida como um momento doloroso e conflituoso, ela também tenha instilado nas participantes deste estudo estratégias de enfrentamento pautadas preferencialmente pela alteridade, representada pelas figuras dos médicos e de Deus.

Entendemos que o momento estudado nos mostra o quanto é importante a presença de profissionais de várias áreas trabalhando conjuntamente com o intuito de 
poder auxiliar as mulheres que necessitam se internar para se submeter à cirurgia por câncer de mama, a enfrentarem essa chegada ao hospital com menos sofrimento e até mesmo prepará-las para o enfrentamento do restante do tratamento. 


\section{CONCLUSÕES}

A compreensão de uma mulher com câncer de mama é sempre uma tarefa desafiadora para os profissionais de saúde que se interessam por esse tema, porque requer dele um olhar do ser mulher diante de uma patologia que a todo instante tenta desafiá-la em sua feminilidade.

A mulher que recebe o diagnóstico de câncer de mama, aderindo ao tratamento atualmente disponível, é colocada diante de uma das fases desse tratamento, que é a cirurgia. Para que essa possa ser realizada há a necessidade da hospitalização. Constituindo-se esse em um dos momentos pelos quais, uma mulher com câncer de mama, necessita enfrentar.

Direcionando nosso olhar para esse momento, propusemo-nos a compreender as representações sociais de dez mulheres que foram admitidas por ocasião da cirurgia por câncer de mama, entendendo que essas representações pudessem estar relacionadas com muitas das estratégias de enfrentamento utilizadas por essas mesmas mulheres.

As observações e entrevistas realizadas nos forneceram dados suficientes para afirmarmos que, os significados atribuídos pelas entrevistadas ao câncer de mama foram: um negócio que enraíza, um peso, uma doença, uma dor, um problema e uma marca. E as representações sociais frente à admissão hospitalar para a realização da cirurgia por câncer de mama, foram: a perda da mama, o medo da morte, a cura, o cuidado enquanto estratégia de retorno à saúde e, por último, um dia normal. 
A relação entre os significados do câncer de mama e as representações relacionadas à cirurgia no momento da admissão hospitalar mostra que esse grupo de mulheres enfrentou vários conflitos no momento da internação, porque elas reconheceram a importância da cirurgia, mas, ao mesmo tempo a perceberam enquanto um procedimento que poderia lhes trazer prejuízos também.

Todas as representações sociais encontradas estão constituídas por uma história coletiva e individual. Essas construções nos permitiram compreender que as representações identificadas não possuem, quase que em sua totalidade, significados diferentes daqueles de sua criação e instituição enquanto conceitos.

O hospital significou principalmente um local em que acontece a cura e a morte. Esses dois significados são os mesmos relatados por Foucault (1979) no que diz respeito à instituição do hospital. Essa semelhança nos aponta para o quanto essas representações sociais ainda estão presentes nas relações que os indivíduos estabelecem com a instituição hospitalar e vice-versa.

A prevalência do hospital como um lugar de cura e de morte toca na possibilidade do reinício da vida e/ou na sua finitude, ou seja, o hospital sempre parece remeter à vida e essa sempre foi a preocupação central do homem e o alicerce de sua angústia existencial (Pierre, 1998).

A vida ocupa então o desejo fundamental dos seres humanos. Ela é uma possibilidade que parece se concretizar apenas através de figuras de poder, que em nosso estudo emergiram preferencialmente por intermédio de Deus e dos médicos.

Ainda segundo Foucault (1998), o hospital também é um lugar em que saber e poder estão sempre presentes, estabelecendo uma relação de interdependência. A ligação entre esses dois conceitos concretizou-se na escolha dos médicos e de Deus pelas participantes deste estudo. Eles representaram o poder de possibilitar a continuidade da vida e o lidar com as ausências instituídas pela admissão hospitalar. Mas, esse poder pôde se fazer presente porque Deus tem seu saber afirmado pelas religiões e pela fé individual, e os médicos, pelo fato de terem construído sua ciência diretamente ligada à busca da cura, que é o que um doente mais almeja.

A admissão hospitalar representada principalmente através da cura e da morte indicia também uma lacuna no conhecimento dos sujeitos estudados e/ou algo que faltou ou falhou nos diálogos estabelecidos entre os profissionais de saúde que os 
acompanharam antes mesmo de entrarem no hospital para a realização da cirurgia por câncer de mama e essas mesmas mulheres.

Os profissionais de saúde inseridos no hospital são os mais indicados para apresentar a instituição hospitalar como um local não mais só de morte e um local em que a cura dificilmente é alcançada apenas com uma internação, como no caso do câncer de mama. Entretanto, a enfermaria na qual os dados deste estudo foram coletados está inserida em um hospital universitário, onde a cada consulta geralmente há um residente diferente para atender o mesmo doente. Sendo assim, não há um espaço de tempo cronológico e nem mesmo a possibilidade do estabelecimento de vínculos, que seriam condições fundamentais para o estabelecimento do ouvir e do se fazer ouvir, portanto, fica estabelecida a despersonalização tanto do doente quanto do profissional que o assiste (Goffman, 1992; Angerami, 2001).

O movimento de apagamento das mulheres estudadas repetiu-se no momento em que foram recebidas por $90 \%$ dos profissionais responsáveis por suas internações, por não terem se apresentado à essas mulheres e tão pouco terem tratado-as por seus nomes, salvo no momento em que foram chamadas para serem levadas aos quartos em que permaneceriam internadas.

Os profissionais observados, porém, ainda apresentaram movimentos de tentativa de estabelecimento de vínculos positivos e de ouvir as mulheres que ali chegaram, o que evidencia a busca desses profissionais em romper até mesmo com o saber diante do qual estão inseridos, que apresenta a admissão hospitalar como um procedimento no qual os aspectos físicos necessitam preferencialmente sua abordagem e análise.

Entendemos, portanto, que a admissão hospitalar de uma mulher para a realização da cirurgia por câncer de mama está perpassada por toda a ideologia hospitalar que é capaz de destituir o doente de seu self. Esse momento também é construído pelo saber que cada profissional de saúde que compõe o hospital é formado, não há como apagar ainda o modo como cada um desses profissionais utiliza seu saber. E em meio a toda essa rede está uma mulher que necessita enfrentar essa chegada ao hospital.

Em 70\% das mulheres estudadas a admissão hospitalar foi vivenciada em um contínuo de representações e estratégias de enfrentamento inter-relacionadas entre si. 
A representação social categorizada como medo da morte foi a que mais influenciou na escolha das estratégias de enfrentamento utilizadas pelas participantes deste estudo. Ela despertou nessas mulheres comportamentos de submissão; a escolha de Deus; a verborragia e a necessidade de controle.

A segunda categoria que mais influenciou na escolha das estratégias de enfrentamento das entrevistadas foi a cura. Ela esteve relacionada a estratégias como a tranqüilidade, a busca de informações e a busca interna.

As representações sociais da admissão hospitalar como um cuidado enquanto estratégia de retorno à saúde e dia normal também estiveram relacionadas à estratégia de enfrentamento tranqüilidade.

Percebe-se que as representações sociais: cura, o cuidado enquanto estratégia de retorno à saúde e dia normal, referentes à admissão hospitalar necessária para a realização da cirurgia por câncer de mama, auxiliaram no enfrentamento desse momento porque possibilitaram a busca de informações e a busca interna, que consideramos estratégias adequadas para o enfrentamento da admissão hospitalar para uma mulher que se submeterá à cirurgia por câncer de mama.

A representação social da admissão hospitalar enquanto medo da morte não foi capaz de fornecer o suporte adequado às mulheres que dela se utilizaram, pelo fato de ter despertado: submissão, a escolha de Deus, a verborragia e a necessidade de controle, que não consideramos estratégias totalmente eficazes por não evidenciarem a implicação dessas mulheres com suas reais condições.

Entendemos que a presença da verborragia em algumas das entrevistadas responde nosso pressuposto de que a ansiedade é uma estratégia de enfrentamento contra a angústia da hospitalização e do câncer também.

Os resultados desse estudo evidenciam que uma mulher que é internada em um hospital para se submeter à cirurgia por câncer de mama tem que ser escutada pelos profissionais responsáveis por sua admissão, porque sem esse escutar jamais serão identificadas as reais necessidades dessa pessoa. Essa disposição é condição fundamental para que haja a verificação do significado da internação para essa mulher e o quanto e de que maneira esse está relacionado às estratégias de enfrentamento utilizadas por ela. 
O escutar será capaz de proporcionar aos profissionais envolvidos na admissão hospitalar a possibilidade de instilar estratégias de enfrentamento mais eficazes para o momento da internação. Isso proporcionará mais tranqüilidade a quem chega para ser cuidado dentro do hospital e resultará em uma recuperação muito mais rápida porque o ambiente hospitalar poderá ser vivenciado sem sua estranheza inerente.

Porém, o escutar implica em subjetividade, o que é algo de difícil estabelecimento dentro de um hospital. Por isso, uma das maneiras de assegurar o estabelecimento dessa subjetividade seria sua presença no protocolo já existente que é preenchido na admissão das mulheres na enfermaria estudada.

Um outro estudo seria necessário para a construção desse adendo ao protocolo utilizado atualmente, o que seria de grande valia porque os direitos subjetivos daquele que chegaria ao hospital para ser cuidado estariam assegurados de forma concreta. Além disso, seria importante para que os profissionais possuíssem mais dados em relação ao doente e a possibilidade de prestarem uma assistência em que corpo, mente e espírito pudessem estar mais integrados. 


\author{
ANEXO B \\ HOSPITAL DAS CLÍNICAS DA FACULDADE DE MEDICINA DE RIBEIRÃO \\ PRETO DA UNIVERSIDADE DE SÃO PAULO \\ Câmpus Universitário Monte Alegre - Fone: 633-1000 - Fax: 633-1144 \\ Cep: 14048-900 RIBEIRÃO PRETO - SÃO PAULO
}

\title{
TERMO DE CONSENTIMENTO PÓS - INFORMACÃO Profissionais
}

NOME DA PESQUISA: Representações sociais de mulheres frente à admissão hospitalar para a realização da cirurgia por câncer de mama.

PESQUISADOR RESPONSÁVEL: Cintia Bragheto. CRP N

$\underline{06 / 57858-9}$

ORIENTADORA: Prof. ${ }^{\text {a }}$ Dra. Ana Maria de Almeida. $\underline{\text { COREN }}$

$\underline{\mathrm{N}^{\mathrm{o}}: 13742 .}$

Telefone para contato: $602-3432$

\section{PATROCINADOR QUE APÓIA FINANCEIRAMENTE A PESQUISA:- Conselho Nacional de Desenvolvimento Científico e Tecnológico - CNPq.}

Esta pesquisa pretende compreender como é para uma mulher ser internada para fazer a cirurgia por câncer de mama, lembrando que essa é uma situação que desperta muitos significados.

Os objetivos desta pesquisa são: identificar como a mulher vê sua chegada ao hospital; o que essa chegada a faz pensar; e, de que formas ela se utiliza para passar por ela. E para que essa compreensão possa ser mais globalizada é importante a observação do modo como a mulher é recebida pelos profissionais que realizam a admissão hospitalar.

Sua participação não é obrigatória, ou seja, você decidirá pela sua participação ou não neste estudo.

Se você concordar em participar a você é dado o direito de desistir em qualquer momento da pesquisa, sem precisar apresentar justificativas para essa desistência. Você não será identificada em momento algum porque apenas ficarão registradas as letras iniciais do seu nome. Essa participação não fará que você fique exposta a risco algum.

Os resultados desta pesquisa poderão nos fornecer condições de entender o que é para uma mulher entrar em um hospital para passar pela cirurgia por câncer de mama. 
EU

R.G. , abaixo assinado, tendo recebido as informações acima, e ciente dos meus direitos abaixo relacionados, concordo em participar.

1- A garantia de receber a resposta a qualquer pergunta ou esclarecimento a qualquer dúvida acerca dos procedimentos, riscos, benefícios e outros relacionados com a pesquisa e o tratamento a que serei submetido;

2- A liberdade de retirar meu consentimento a qualquer momento e deixar de participar no estudo sem que isso traga prejuízo à continuação do meu cuidado e tratamento;

3- A segurança de que não serei identificado e que será mantido o caráter confidencial da informação relacionada com a minha privacidade;

4- O compromisso de me proporcionar informação atualizada durante o estudo, ainda que esta possa afetar minha vontade de continuar participando.

5- O compromisso de que serei devidamente acompanhado e assistido durante todo o período de minha participação no projeto, bem como de que será garantida a continuidade do meu tratamento, após a conclusão dos trabalhos da pesquisa.

6- O ressarcimento de eventuais despesas decorrentes da minha participação no projeto, a ser promovido pelo pesquisador.

7- Que o ressarcimento de eventuais despesas, bem como a indenização, a título de cobertura material, para reparação de danos imediatos ou tardios, decorrentes de minha participação na pesquisa, serão feitos pelo pesquisador (Patrocinador da Pesquisa), não cabendo ao Hospital das Clínicas de Ribeirão Preto, qualquer responsabilidade quantos aos referidos pagamentos.

Tenho ciência do exposto acima e desejo participar desta pesquisa como forma de contribuir com o responsável que subscreve este documento.

Ribeirão Preto, de de 


\section{ANEXO C}

Instrumento para o momento de observação do principal profissional envolvido na admissão hospitalar

Nome (iniciais):

Início:

Término:

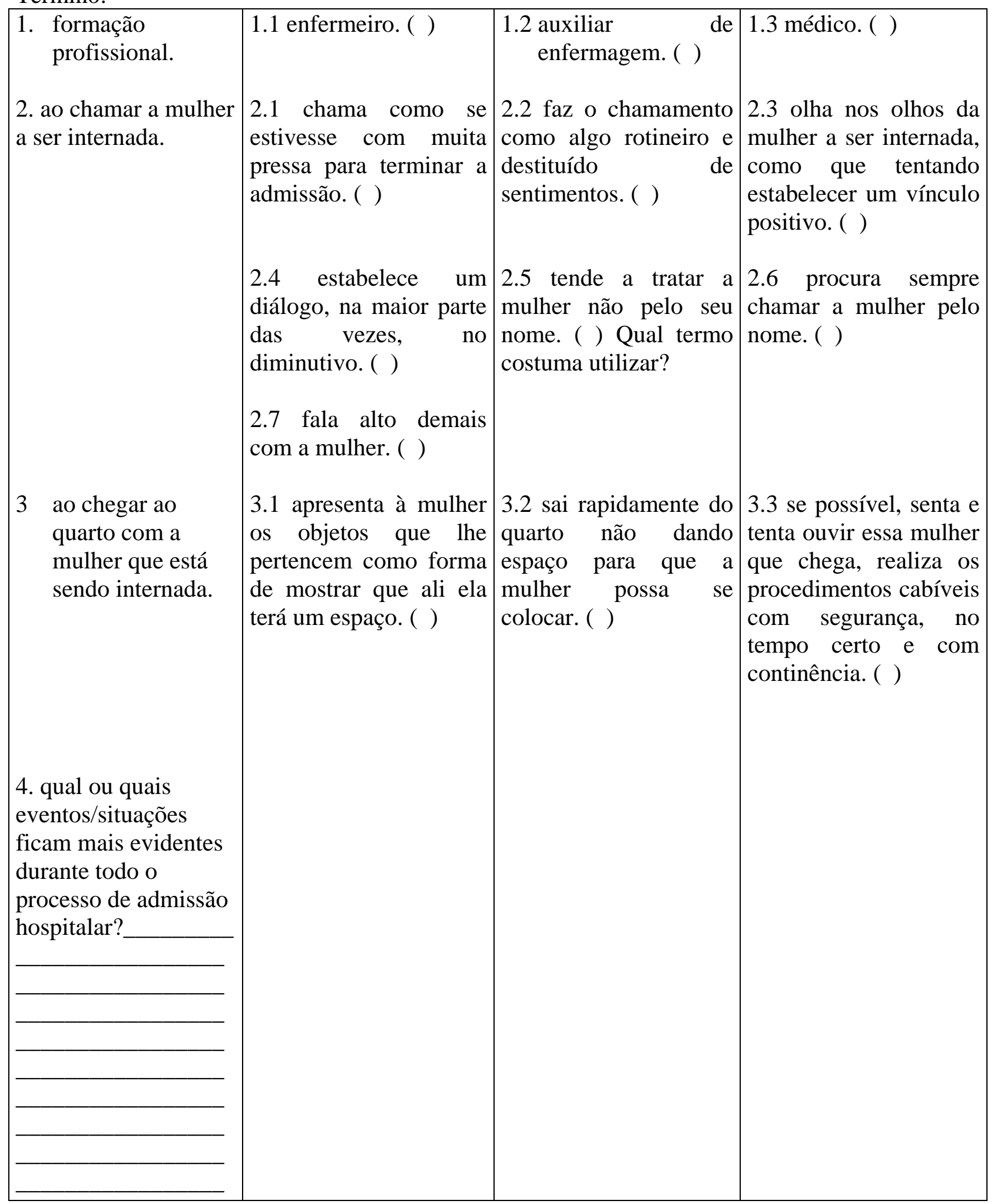




\section{ANEXO D \\ HOSPITAL DAS CLÍNICAS DA FACULDADE DE MEDICINA DE RIBEIRÃO PRETO DA UNIVERSIDADE DE SÃO PAULO \\ Câmpus Universitário Monte Alegre - Fone: 633-1000 - Fax: 633-1144 \\ Cep: 14048-900 RIBEIRÃO PRETO - SÃO PAULO \\ TERMO DE CONSENTIMENTO PÓS - INFORMACCÃO Mulheres}

NOME DA PESQUISA: Representações sociais de mulheres frente à admissão hospitalar para a realização da cirurgia por câncer de mama.

PESQUISADOR RESPONSÁVEL: Cintia Bragheto.CRP

$\mathrm{N}^{\circ} 06 / 57858-9$

ORIENTADORA: Prof. ${ }^{a}$ Dra. Ana Maria de Almeida. $\underline{\text { COREN }}$

$\underline{\mathrm{N}^{\mathrm{o}}: 13742 .}$

Telefone para contato: $602-3432$

PATROCINADOR QUE APÓIA FINANCEIRAMENTE A

PESQUISA:- Conselho Nacional de Desenvolvimento Científico e

Tecnológico - CNPq.

Esta pesquisa pretende compreender como é para uma mulher ser internada para fazer a cirurgia por câncer de mama, lembrando que essa é uma situação que desperta muitos significados.

Os objetivos desta pesquisa são: identificar como você vê sua chegada neste hospital; o que essa chegada te faz pensar; e, de que formas você se utiliza para passar por ela. Sua participação não é obrigatória, ou seja, você decidirá pela sua participação ou não neste estudo.

Se você concordar em participar a você é dado o direito de desistir em qualquer momento da pesquisa, sem precisar apresentar justificativas para essa desistência. Essa desistência não fará com que você seja prejudicada em nenhum atendimento dentro deste hospital. Você não será identificada em momento algum porque apenas ficarão registradas as letras iniciais do seu nome. Se você concordar, suas respostas serão gravadas em um gravador. Esta entrevista terá uma duração de aproximadamente 30 minutos e não te causará risco algum.

Os resultados desta pesquisa poderão nos fornecer condições de entender o que é para uma mulher entrar em um hospital para passar pela cirurgia por câncer de mama. 
EU

R.G. , abaixo assinado, tendo recebido as informações acima, e ciente dos meus direitos abaixo relacionados, concordo em participar.

8- A garantia de receber a resposta a qualquer pergunta ou esclarecimento a qualquer dúvida acerca dos procedimentos, riscos, benefícios e outros relacionados com a pesquisa e o tratamento a que serei submetido;

9- A liberdade de retirar meu consentimento a qualquer momento e deixar de participar no estudo sem que isso traga prejuízo à continuação do meu cuidado e tratamento;

10- A segurança de que não serei identificado e que será mantido o caráter confidencial da informação relacionada com a minha privacidade;

11- O compromisso de me proporcionar informação atualizada durante o estudo, ainda que esta possa afetar minha vontade de continuar participando.

12- O compromisso de que serei devidamente acompanhado e assistido durante todo o período de minha participação no projeto, bem como de que será garantida a continuidade do meu tratamento, após a conclusão dos trabalhos da pesquisa.

13- O ressarcimento de eventuais despesas decorrentes da minha participação no projeto, a ser promovido pelo pesquisador.

14- Que o ressarcimento de eventuais despesas, bem como a indenização, a título de cobertura material, para reparação de danos imediatos ou tardios, decorrentes de minha participação na pesquisa, serão feitos pelo pesquisador (Patrocinador da Pesquisa), não cabendo ao Hospital das Clínicas de Ribeirão Preto, qualquer responsabilidade quantos aos referidos pagamentos.

Tenho ciência do exposto acima e desejo participar desta pesquisa como forma de contribuir com o responsável que subscreve este documento.

Ribeirão Preto, de de 
ANEXO E

Instrumento para o momento de observação da mulher a ser submetida à cirurgia por câncer de mama

Nome (iniciais):

Idade: Procedência:

Escolaridade:

Estado civil:

Profissão:

Paridade G P A Cirurgia Proposta:

Início:

Término:

\begin{tabular}{|c|c|c|}
\hline 1. chegada a enfermaria. & 1.1 só. ( ) & 1.2 acompanhada. ( ) \\
\hline $\begin{array}{l}\text { 2. ao ser chamada pelo nome } \\
\text { para ser levada ao quarto. }\end{array}$ & $\begin{array}{l}2.1 \text { demonstra estar implicada } \\
\text { com a situação de } \\
\text { internação. ( ) }\end{array}$ & $\begin{array}{l}2.2 \text { demonstra resposta ao } \\
\text { estímulo do chamado porque } \\
\text { já está ali mesmo. ( ) }\end{array}$ \\
\hline $\begin{array}{l}\text { 3. ao acompanhar o } \\
\text { profissional até o quarto. }\end{array}$ & $\begin{array}{l}3.1 \text { como inicia o diálogo com } \\
\text { o profissional que está } \\
\text { realizando a admissão? }\end{array}$ & $\begin{array}{l}3.2 \text { permanece em silêncio até } \\
\text { chegar ao quarto. ( ) }\end{array}$ \\
\hline $\begin{array}{l}\text { 4. se acompanhada, como é a } \\
\text { despedida. }\end{array}$ & $\begin{array}{l}4.1 \text { despede-se do } \\
\text { acompanhante na saída da } \\
\text { sala de espera. ( ) }\end{array}$ & $\begin{array}{l}4.2 \quad \text { despede-se do } \\
\text { acompanhante após a entrada no } \\
\text { quarto. ( ) }\end{array}$ \\
\hline & $\begin{array}{l}4.3 \text { fala bastante, passa as } \\
\text { últimas coordenadas quanto ao } \\
\text { funcionamento do lar em sua } \\
\text { ausência, assegura que ficará } \\
\text { bem e que logo estará de volta. } \\
\text { ( ) }\end{array}$ & $\begin{array}{l}4.4 \text { despede-se de forma } \\
\text { contida, parece esconder aquilo } \\
\text { que sente e/ou pensa. ( ) } \\
4.5 \text { integrada com o que pensa } \\
\text { e/ou sente. ( ) }\end{array}$ \\
\hline $\begin{array}{l}5 \text { como se posiciona frente ao } \\
\text { profissional que está } \\
\text { realizando a admissão. } \\
\text { 6. qual ou quais sentimentos } \\
\text { ficam mais evidentes durante } \\
\text { todo o processo de admissão } \\
\text { hospitalar? }\end{array}$ & $\begin{array}{l}5.1 \text { coloca-se de forma } \\
\text { submissa, realiza apenas o que } \\
\text { lhe é proposto. ( ) }\end{array}$ & $\begin{array}{l}\text { 5.2. coloca-se de forma } \\
\text { controladora, tenta a todo } \\
\text { momento fazer com que o } \\
\text { profissional faça aquilo que ela } \\
\text { acha que seria o adequado. ( ) } \\
\begin{array}{l}5.3 \text { coloca-se de forma a } \\
\text { estabelecer uma relação } \\
\text { harmoniosa. ( ) }\end{array}\end{array}$ \\
\hline $\begin{array}{l}\text { 7. qual ou quais formas de } \\
\text { enfrentamento verbaliza ou } \\
\text { demonstra de forma } \\
\text { comportamental durante todo } \\
\text { o processo de admissão } \\
\text { hospitalar? }\end{array}$ & & \\
\hline
\end{tabular}




\section{ANEXO F}

Instrumento para o momento da confecção do diário de campo

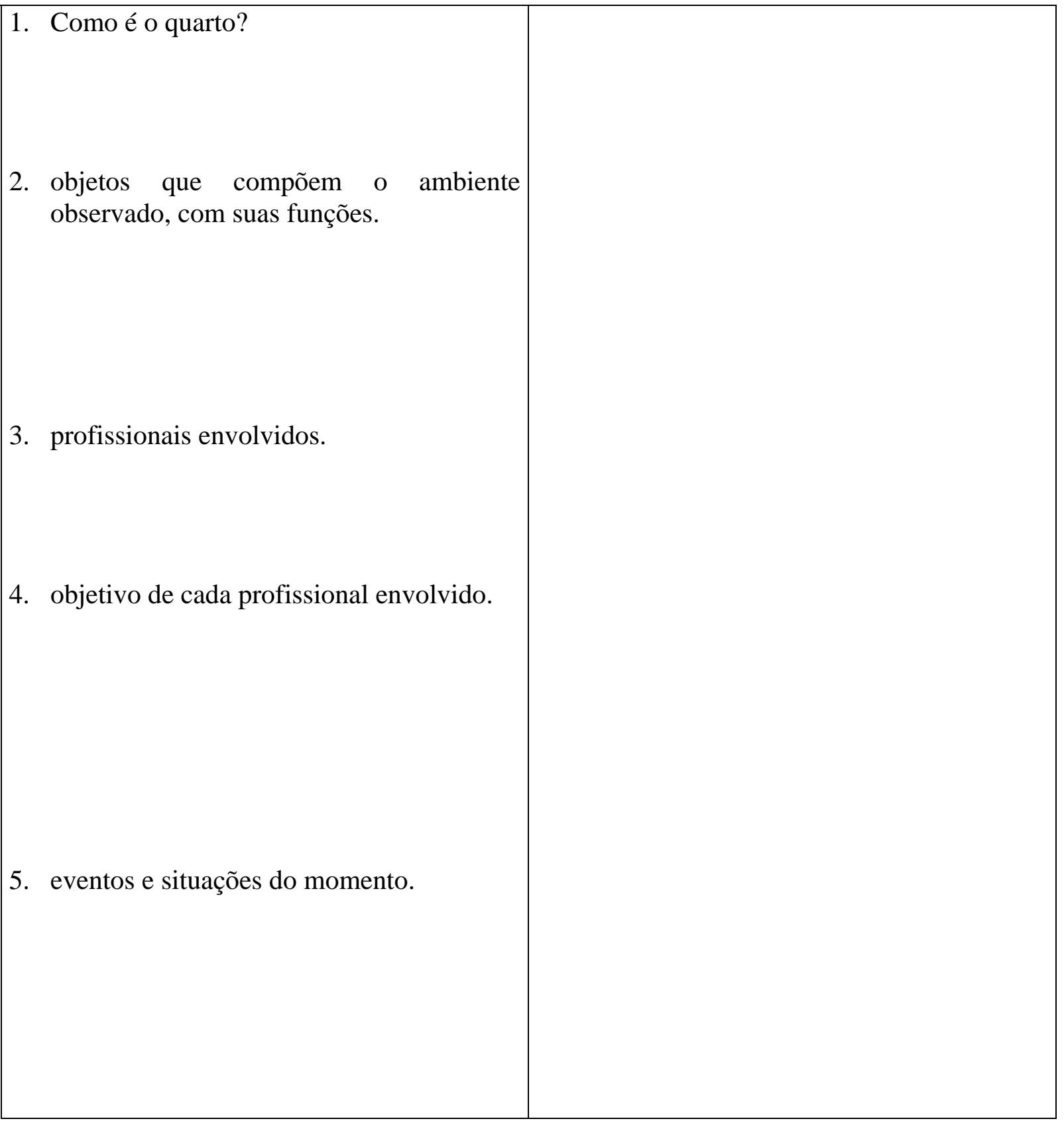


ANEXO G

NORMAS PARA TRANSCRIÇÃO*

\begin{tabular}{|c|c|c|}
\hline OCORRÊNCIAS & SINAIS & EXEMPLIFICAÇÃO \\
\hline $\begin{array}{l}\text { Incompreensão de palavras } \\
\text { ou segmentos }\end{array}$ & () & $\begin{array}{l}\text { do nível de renda... ( ) } \\
\text { nível de renda nominal... }\end{array}$ \\
\hline Hipótese do que se ouviu & (hipótese) & $\begin{array}{l}\text { (estou) meio preocupado } \\
\text { (com o gravador) }\end{array}$ \\
\hline $\begin{array}{l}\text { Truncamento } \\
\text { (havendo } \\
\text { homografia, usa-se acento } \\
\text { indicativo da tônica e/ou } \\
\text { timbre). }\end{array}$ & / & e comé/ e reinicia \\
\hline Entonação enfática & maiúscula & $\begin{array}{l}\text { porque as pessoas reTÊM } \\
\text { moeda }\end{array}$ \\
\hline $\begin{array}{l}\text { Prolongamento de vogal e } \\
\text { consoante (como s, r) }\end{array}$ & $\begin{array}{c}:: \text { podendo aumentar para }::: \\
\text { ou mais }\end{array}$ & $\begin{array}{l}\text { ao emprestarem os_éh }:::_{-} 0 \\
\text { dinheiro }\end{array}$ \\
\hline Silabação & - & por motivo tran-sa-ção \\
\hline Interrogação & $?$ & e o Banco- Central- certo? \\
\hline Qualquer pausa & $\ldots$ & $\begin{array}{l}\text { são três motivos_ as três } \\
\text { razões_que fazem com que } \\
\text { se retenha moeda_ existe } \\
\text { uma_retenção }\end{array}$ \\
\hline $\begin{array}{l}\text { Comentários descritivos do } \\
\text { transcritor }\end{array}$ & ((minúscula)) & $(($ tossiu $))$ \\
\hline $\begin{array}{l}\text { Comentários que quebram a } \\
\text { seqüência temática da } \\
\text { exposição; desvio temático }\end{array}$ & -- -- & $\begin{array}{l}\text {-- a demanda de moeda -- } \\
\text { vamos dar essa notação - } \\
\text { demanda de moeda por } \\
\text { motivo }\end{array}$ \\
\hline $\begin{array}{l}\text { Superposição, } \\
\text { simultaneidade de vozes }\end{array}$ & $\begin{array}{l}\text { ligando as } \\
\text { linhas[ }\end{array}$ & $\begin{array}{l}\text { A na casa da sua irmã [ } \\
\text { B } \\
\text { feira? } \\
\text { A fizeram lá__ } \\
\text { B r cozta- } \\
\end{array}$ \\
\hline $\begin{array}{l}\text { Indicação de que a fala foi } \\
\text { tomada ou interrompida em } \\
\text { determinado ponto. Não no } \\
\text { seu início, por exemplo. }\end{array}$ & $(-)$ & (-) nós vimos que existem- \\
\hline $\begin{array}{l}\text { Citações literais ou leituras } \\
\text { de textos, durante a gravação }\end{array}$ & “” & $\begin{array}{l}\text { Pedro Lima_ ah escreve na } \\
\text { ocasião_ "O cinema falado } \\
\text { em língua estrangeira não } \\
\text { precisa de nenhuma } \\
\text { baRREIra entre nós"_. }\end{array}$ \\
\hline
\end{tabular}

*PRETI, D. (Org.). Análise de textos orais. São Paulo: Humanitas Publicações, 1999. 237 p. 


\section{REFERÊNCIAS BIBLIOGRÁFICAS}

ALVES, R. O que é religião? São Paulo: Loyola, 2002. 126 p.

ANDSAGER, J.L.; HUST, S.J.T.; POWERS, A. Patient-blaming and representation of risk factors in breast cancer images. Women \& Health, Washington, v.31, n.2/3, p.57-79, 2000.

ANGERAMI, V.A. Psicologia hospitalar: teoria e prática. São Paulo: Pioneira, 2001. 114 p.

ARANTES, S.L. A participação das mulheres com câncer de mama na escolha do tratamento: um direito a ser conquistado. Ribeirão Preto, 2002. 184p. Tese (Doutorado) - Escola de Enfermagem, Universidade de São Paulo, Ribeirão Preto.

ARIÈS, P. História da morte no ocidente: da idade média aos nossos dias. Rio de Janeiro: Francisco Alves, 1977. 180 p.

AUTHIER-REVUZ, J. Palavras incertas: as não-coincidências do dizer. Campinas, Unicamp, 1998.

BARBARIN, G. O livro da morte doce: como não temer mais o instante da morte. São Paulo: Paulus, 1997. 205 p.

BELAND, Y.; PASSOS, J. Enfermagem clínica. São Paulo: EPU-EDUSP, 1978.

BERGAMASCO, R.B. O sofrimento de descobrir-se com câncer de mama: como o diagnóstico é experienciado pela mulher. 1999. 119p. Tese (Doutorado) Escola de Enfermagem de São Paulo, Universidade de São Paulo, São Paulo. 
BERNARDES, J.S. Histórias. In: Strey, M.N. et al. Psicologia Social Contemporânea. Petrópolis: Vozes, 2001. cap. 1, p. 19-35.

BITTENCOURT, J.F.V.; CADETE, M.M.M. Deus é presença incondicional à mulher com possibilidade de vir a ser mastectomizada. Ver. Min. Enf., Belo Horizonte, v. 6, n. 1/2, p.73-76, 2002.

BOFF, L. Saber cuidar: ética do humano - compaixão pela terra. Petrópolis: Vozes, 1999. 199 p.

Experimentar deus: a transparência de todas as coisas. Campinas: Verus, 2002. 163 p.

BOGDAN, R.; BIKLEN, S. Investigação qualitativa em educação. Porto: Porto, 1994. 336 p.

BRASIL. Rio de Janeiro, Instituto Nacional do Câncer, 2001. O câncer no Brasil. Disponível em: <http://www.inca.org.br>. Acessado em 15 mar. 2001a.

BRASIL. Rio de Janeiro, Instituto Nacional do Câncer, 1999. Aumento da expectativa de vida. Disponível em: <http://www.inca.org.br>. Acessado em: 25 out. 1999b.

BRASIL. Rio de Janeiro, Instituto Nacional do Câncer, 2001. Estimativa da incidência e mortalidade por câncer no Brasil. Disponível em: <http://www.inca.org.br>. Acessado em 15 mar. 2001c.

BRASIL. Rio de Janeiro, Instituto Nacional do Câncer, 1999. Câncer de Mama. Disponível em: <http://www.inca.org.br>. Acessado em: 25 out. 1999d. 
BRASIL. Rio de Janeiro, Instituto Nacional do Câncer, 2003. Estimativa da incidência e mortalidade por câncer no Brasil. Disponível em: <http://www.inca.org.br>. Acessado em: 10 jul. 2003e.

BROWN, R.F. et al. Responding to the active and passive patient: flexibility is the key. Health Expect., Australia, v.5, n.3, p. 236-45, 2002.

BRUERA, E. et al. Treatment decisions for breast carcinoma: patient preferences and physician perceptions. Cancer., Texas, v.94, n7, p. 2076-80, 2002.

CARAPINHEIRO, G. Saberes e poderes no hospital: uma sociologia dos serviços hospitalares. Porto: Afrontamento, 1993. 295 p.

CASTRO, R.V. Representações sociais da prostituição na cidade do rio de janeiro. In: SPINK, M.J.P. (Org.). $\mathrm{O}$ conhecimento no cotidiano: as representações sociais na perspectiva da psicologia social. São Paulo: Brasiliense, 1995. p. 149-187.

CHIZZOTTI, A. Pesquisa em ciências humanas e sociais. São Paulo: Cortez, 1991.

CORBELLINI, V.L.; COMIOTTO, M.S. ...Hoje eu me sinto em paz, eu deito agradecendo a deus; se nós não temos fé, nós não somos ninguém. O Mundo da Saúde, São Paulo, v.24, n.6, p.510-514, 2000.

DEBUS, M. Manual para excelencia en la investigación mediante grupos focales. Washington: Health Com Agency for Internacional Development, 1994. DIAS, M.R. A esmeralda perdida: a informação ao doente com cancro da mama. Lisboa: ISPA, 1997. 340 p.

DURKHEIM, É. As regras do método sociológico. São Paulo: Abril Cultural, 1978. 
EPPING-JORDAN, J.E. et al. Psychological adjustment in breast cancer: processes of emotional distress. Health Psychology, Vermont, v.18, n.18, p.315326, 1999.

FARR, R.M. Representações sociais: a teoria e sua história. In: GUARESCHI, P. \& JOVCHELOVITCH, S. (Orgs.). Textos em representações sociais. Petrópolis: Vozes, 2000. cap. 1, p. 31-59.

FERREIRA, A.B.H. Novo Dicionário da língua portuguesa. 2. ed. Rio de Janeiro: Nova Fronteira, 1986. 1838 p.

FOUCAULT, M. O nascimento do hospital. In: FOUCAULT, M. Microfísica do poder. Glória, RJ: Graal, 1979, p.99-109.

O nascimento da clínica. 3. ed. Rio de Janeiro: Forense-Universitária, 1987. $241 \mathrm{p}$.

. Microfísica do poder. 13. ed. Rio de Janeiro: Graal, 1998. 295 p.

FREUD, S. Sobre as teorias sexuais das crianças. In: . "Gradiva” de

Jensen e outros trabalhos. Rio de Janeiro: Imago, 1980a. p. 213-228.

Análise de uma fobia em um menino de cinco anos. In: Duas

histórias clínicas (o “pequeno Hans” e o “homem dos ratos”). Rio de Janeiro: Imago, 1980b. p. 15-154.

FUX, S.P. Psicossomática: uma questão para a psicanálise. Correio: Revista da Escola Brasileira de Psicanálise, Rio de Janeiro, n.35, p.18-27, 2001.

GAIARSA, A. O que é a angústia. São Paulo: Brasiliense, 1999. 83p. 
GANDINI, R.C. Evolução da eficácia adaptativa em mulheres mastectomizadas. São Paulo: USP, 1995.

GARCIA, H.F. Compreendendo a necessidade do paciente com câncer de receber orientações para a cirurgia: implicações da visita pré-operatória pelo enfermeiro. Rev. Bras. Cancerol., Rio de Janeiro, v.45, n.2, p.15-26, 1999.

GIL, A.C. Métodos e técnicas de pesquisa social. 5. ed. São Paulo: Atlas, 1999. 206 p.

GIMENEZ, M.G.G., QUEIROZ,E., SHAYER,B.P.M. Reações emocionais diante do câncer: sugestões para intervenção. Arq. Bras. Med., São Paulo, vol.66, n.4, p.353-56, 1992.

A mulher e o câncer. Campinas: Psy, 1997. 321 p.

GOFFMAN, E. Manicômios, prisões e conventos. 4.ed. São Paulo: Perspectiva, 1992. 312 p.

GUARESCHI, P.; JOVCHELOVITCH, S. (Orgs.). Textos em representações sociais. Petrópolis: Vozes, 2000. 324 p.

GUARESCHI, N.M.F. A criança e a representação social de poder e autoridade: negação da infância e afirmação da vida adulta. In: SPINK, M.J.P. (Org.). O conhecimento no cotidiano: as representações sociais na perspectiva da psicologia social. São Paulo: Brasiliense, 1995. p. 212-233.

HAGUETTE, T.M.F. Metodologias qualitativas na sociologia. Petrópolis: Vozes, 1995. 
JODELET, D. La representación social: fenómenos, concepto y teoria. In: MOSCOVICI, S. (Ed.). Psicologia Social y Problemas Sociales. Buenos Aires: Paidos, 1986, p. 469-493.

KEATING, N.L. et al. Treatment decision making in early-stage breast câncer: should surgeons match patients' desired level involvement? J. Clin. Oncol., Massachusetts, v.20, n6, p.1473-9, 2002.

KOVÁCS, M.J. Morte e desenvolvimento humano. São Paulo: Casa do Psicólogo, 1992. 243 p.

KUBLER-ROSS, E. Sobre a morte e o morrer: o que os doentes têm para ensinar a médicos, enfermeiras, religiosos e aos seus parentes. 7. ed. São Paulo: Martins Fontes, 1996. 299 p.

LACAN, J. O seminário-livro 11: os quatro conceitos fundamentais da psicanálise. 2. ed. Rio de Janeiro: Jorge Zahar Editor, 1988.

LAPLANTINE, F. Antropologia da doença. São Paulo: Martins Fontes, 1991. $274 \mathrm{p}$.

LAZARUS, S.R.; FOLKMAN, S. Stress, appraisal, and coping. New York: Copyright, 1984. 225p.

LESHAN, L. O câncer como ponto de mutação: um manual para pessoas com câncer, seus familiares e profissionais de saúde. São Paulo: Summus, 1992. 195 p.

MCCAIN, M.E. Princípios científicos de enfermagem. 2. ed. Rio de Janeiro: Científica, 1970.

MAMEDE, M.V. et al. Câncer: um conceito social. In: Reunião Anual da S.B.P.C., 43, Rio de Janeiro, 1991. Anais. Rio de Janeiro, 1991. p. 73-4. 
MARTINS, C.B. O que é sociologia. 37 ed. São Paulo: Brasiliense, 1994. 98 p.

MINAYO, M.C.S.. Representações da cura no catolicismo popular. In: ALVES, P.C.; MINAYO, M.C.S. (Orgs.). Saúde e doença: um olhar antropológico. Rio de Janeiro: Fiocruz, 1994. cap. 4, p. 57-81.

O desafio do conhecimento. 6. ed. São Paulo Rio de Janeiro: Hucitec Abrasco, 1999. 269 p.

MORAES, M.C. O paciente oncológico, o psicólogo e o hospital. In: CARVALHO, M.M.M.J. (Coord.). Introdução à psiconcologia. Campinas, SP: Psy, 1994. p. 57-63.

MOSCOVICI, S. La psychanalyse, son image et son public. Paris: PUF, 1961.

A representação social da psicanálise. Rio de Janeiro: Jorge Zahar, 1978. 291 p.

NASIO, J.D. Lições sobre os 7 conceitos cruciais da psicanálise. Rio de Janeiro: Jorge Zahar, 1996. 171 p.

NÓBREGA, S.M. O que é representação social. Paris: Ècole des Hautes en Sciences Sociales, 1990. /Mimeografado/

NOGUEIRA, O. Pesquisa social: introdução às suas técnicas. 4.ed. São Paulo: Nacional, 1977.

OGATA, M.N. Concepções de saúde e doença - estudo das representações sociais de profissionais da saúde. 2000. 280 p. Tese (Doutorado) - Escola de Enfermagem de Ribeirão Preto, Universidade de São Paulo, Ribeirão Preto. 
OLIVEIRA, D.C.; RODRIGUES, B.M.R.D.R. A utilização da teoria de representações sociais no campo da enfermagem : uma busca de aproximação. Revista Enfermagem - UERJ, Rio de Janeiro, v.1, n.1, p.260-269, 2001.

OSOWIECK, D.M.; COMPAS, B.E. A prospective study of coping, perceived control, and psychological adaptation to breast cancer. Cogn. Ther. and Res., Vermont, v.23, n.2, p.169-180, 1990.

OLIVEIRA, F.O.F.; WERBA, G.C. Representações Sociais. In: STREY, M.N. et al Psicologia social contemporânea: livro-texto. Petópolis: Vozes, 2001. cap. 2, p.104-117.

PIERRE, C. A arte de viver e morrer. Cotia, SP: Ateliê, 1998. 139 p.

POLIT, D.F.; HUNGLER, B.P. Métodos de coleta de dados. In: POLIT, D.F.; HUNGLER, B.P. (Ed.). Fundamentos de pesquisa em enfermagem. Porto Alegre: Artes Médicas, 1995. cap. 8, p. 163-198.

POLSKY, D. et al. Patient choice of breast cancer treatment: impact on health state preferences. Med. Care., Pennsylvania, v.40, n.11, p.1068-79, 2002.

PRETI, D. (Org.). Análise de textos orais. São Paulo: Humanitas, 1999. 237 p.

QUEIROZ, E. Bem estar psicológico e enfrentamento após mastectomia. 1993. 47p. Tese (Doutorado) - Instituto de Psicologia, Universidade de Brasília, Brasília.

RABELO, M.C.M. Religião, ritual e cura. In: ALVES, P.C.; MINAYO, M.C.S. (Orgs.). Saúde e doença: um olhar antropológico. Rio de Janeiro: Fiocruz, 1994. cap.3, p. 47-56. 
ROCHA, R. Minidicionário enciclopédico escolar. São Paulo: Scipione, 2000. $668 \mathrm{p}$.

RODRIGUES, A. Psicologia Social. 15. ed. Petrópolis: Vozes, 1994. 485 p.

ROMANELLI, G. A entrevista antropológica: troca e alteridade. In: ROMANELLI, G.; ALVES, Z.M.M.B. (Orgs.). Diálogos metodológicos sobre prática de pesquisa. Ribeirão Preto: Legis Summa, 1998. cap. 6, p. 119-133.

SÁ, L.M. O hospital: seres humanos, pacientes e profissionais coexistindo. In: O psicólogo e o hospital. Porto Alegre, Sagra: DC Luzzatto, 1993, p. 92109.

SÁ, C.P. A representação social da economia brasileira antes e depois do "plano real”. In: MOREIRA, A.S.P.; OLIVEIRA, D.C.O. (Orgs.). Estudos interdisciplinares de representação social. Goiânia: AB, 1998. p. 49-69.

- Socialização do saber acadêmico: uma pesquisa sobre a representação social da ciência à luz da teoria do núcleo central. In: Núcleo central das representações sociais. Rio de Janeiro: Vozes, 2002. cap. 4, p. 147-162.

SANDELOWSKI, M. Rigor or rigor mortis: the problem of rigor in qualitative research revisited. Adv. Nurs. Scien., v.16, n.2, p. 1-8, 1993.

SANHUEZA ALVARADO, O. O significado da mama para um grupo de mulheres chilenas com câncer de mama. 1999. 158p. Tese (Doutorado) Escola de Enfermagem de Ribeirão Preto, Universidade de São Paulo, Ribeirão Preto.

SANT’ANA, B.D. A mulher e o câncer na história. In: Gimenez, M.G.G. (Org.). A mulher e o câncer. Campinas: Psy, 1997.cap. 2, p. 43-70. 
SANTOS, G.F. A morte sob a ótica da racionalidade. Enferm rev., Belo Horizonte, v.1, n.2, p. 59-65, 1993.

SATO, L. A representação social do trabalho penoso. In: SPINK, M.J.P. (Org.). O conhecimento no cotidiano: as representações sociais na perspectiva da psicologia social. São Paulo: Brasiliense, 1995. p. 188-211.

SILVA, R.M.; MAMEDE, M.V. Conviver com a mastectomia. Fortaleza: UFC, 1998. 155 p.

SIMONTON, O.C.; MATTHEWS-SIMONTON,S.; CREIGHTON, J.L. Com a vida de novo: uma abordagem de auto-ajuda para pacientes com câncer. São Paulo: Summus,1987. 238 p.

SORDI, M.R.C.; NUNES, M.A.G. O paciente no ambiente hospitalar. In: Manual básico de enfermagem. Campinas, 1988. cap. 1, p. 11-16.

SPINK, M.J.P. O conhecimento no cotidiano: as representações sociais na perspectiva da psicologia social. São Paulo: Brasiliense; 1993a 311 p.

O conceito de representação social na abordagem psicossocial. Cad. Saúde Públ., Rio de Janeiro, v.9, n.3, p.300-308, 1993b.

SPINK, M.J.P. O estudo empírico das representações sociais. In: . $\mathbf{O}$ conhecimento no cotidiano: as representações sociais na perspectiva da psicologia social. São Paulo: Brasiliense, 1995. p. 85-108.

- Desvendando as teorias implícitas: uma metodologia de análise das representações sociais. In: GUARESCHI, P.; JOVCHELOVITCH, S. (Orgs.). Textos em representações sociais. 6. ed. Petrópolis: Vozes, 2000. p. 117-145. 
STREY, M.N. et al Psicologia social contemporânea: livro-texto. Petrópolis: Vozes, 2001. 262 p.

SCHULZE, C.M.N. As representações sociais de pacientes portadores de câncer. In: SPINK, M.J.P. (Org.). O conhecimento no cotidiano: as representações sociais na perspectiva da psicologia social. São Paulo: Brasiliense, 1995. p. 266279.

TIMBY, B.K. Admissão, alta, transferência e encaminhamentos. In:

Conceitos e habilidades fundamentais no atendimento de enfermagem. 6. ed. Porto Alegre: Artes Médicas, 2001. cap. 10, p. 126-137.

TRIVIÑOS, A.N.S. Intodução à pesquisa em ciências: a pesquisa qualitativa em educação. São Paulo: Atlas, 1987.

VALLE, E.R.M. Comportamentos psicológicos apresentados pelo paciente na sua admissão ao hospital - a interação verbal com o profissional de saúde. Hospital Moderno, v.3, n.3, p. 6-10, 1986.

WANDERLEY, K.S. Aspectos psicológicos do câncer de mama. In: CARVALHO, M.M.M.J. (Coord.). Introdução à psiconcologia. Campinas, SP: Psy, 1994. p. 95-101.

YALOM, M. História do seio. Lisboa: Teorema, 1998. 364 p. 